\title{
Parmotrema s.l. (Parmeliaceae, lichenized Ascomycota) from Serra Geral slopes in central Rio Grande do Sul State, Brazil
}

\author{
Adriano Afonso Spielmann ${ }^{1,2}$ and Marcelo Pinto Marcelli ${ }^{1}$
}

Received: 08.12.2008; accepted: 10.09.2009

ABSTRACT - (Parmotrema s.l. (Parmeliaceae, lichenized Ascomycota) from Serra Geral slopes in central Rio Grande do Sul State, Brazil). A survey of the parmotremoid lichens occurring in the central area of Rio Grande do Sul State (Brazil) revealed 31 species of Parmotrema A. Massal., distributed in three groups corresponding to the former genera Canomaculina Elix \& Hale, Parmotrema s. str. and Rimelia Hale \& Fletcher. All species are described, illustrated, commented and special notes compare similar species as an aid to identification.

Key words: Canomaculina, Parmotrema, Rimelia, Rio Grande do Sul

RESUMO - (Parmotrema s.l. (Parmeliaceae, lichenized Ascomycota) de escarpas da Serra Geral na região central do Rio Grande do Sul State, Brasil). Em um levantamento das espécies de Parmotrema A. Massal. que ocorrem nos barrancos e peraus de uma região central do Rio Grande do Sul, 31 espécies foram encontradas, as quais podem ser divididas em três grupos morfológicos, que correspondem a Canomaculina Elix \& Hale, Parmotrema s. str. e Rimelia Hale \& Fletcher. Descrições, ilustrações e comentários sobre espécies próximas são fornecidos, baseando-se no material encontrado.

Palavras-chave: Canomaculina, Parmotrema, Rimelia, Rio Grande do Sul

\section{Introduction}

Continuing the studies on the diversity of Parmeliaceae from Southern Brazil, focused on species found in roadsides and slopes in the central Rio Grande do Sul State (Spielmann 2005, Spielmann \& Marcelli 2008), we are presenting here the most diverse group found: Parmotrema s.1.

Parmotrema was proposed a long time ago (Massalongo 1860) to delimit some species belonging to the genus Parmelia Ach., and Parmotrema perforatum (Wulfen) A. Massal. was chosen as the type. The name Parmotrema reports the perforate apothecia of this species, from the Greek parmos $=$ cup, and trema = perforation (Feige 1998). The genus was largely neglected by the contemporary workers, maybe with the exception of Krempelhuber (Hale 1984), and the species belonging to Parmotrema were dealt with in the large genus Parmelia Ach. by Zahlbruckner(1926a,1930). Vainio (1890) assembled most species at present placed in Parmotrema in his Parmelia section Amphigymnia Vainio, and his delimitation was largely followed, sometimes with slight changes. Dodge (1959), for example, proposed Parmelia subgenus Amphigymnia (Vainio) Dodge, and with this name, the species were monographically treated by Hale (1965). In this meantime, some combinations in Parmotrema were proposed by $\mathrm{M}$. Choisy, as can be seen in Lamb (1963). Later, Hale (1974a) recognized Parmotrema and placed in it the species studied in his monograph of Amphigymnia (Hale 1965). Therefore, Parmotrema began to be widely used. Nevertheless, some workers (e.g. Hawksworth, Dey, Krog, and Swinscow) do not accept this delimitation (Culberson 1991). Krog \& Swinscow (1983) changed their mind, yet until recently (see Purvis et al. 1992) some Europeans still do not used Parmotrema (and no one of the genera proposed by Hale). Today the generic delimitation in Parmeliaceae is very controversial, but several Hale's propositions are more widely used (see, e.g., Hawksworth et al. 2008).

The genus Canomaculina was proposed by Elix \& Hale (1987) to accommodate three species previously classified within Parmelina Hale (Hale 1974b, 1976): C. consors (Nyl.) Elix \& Hale, $C$. muelleri (Vainio) Elix \& Hale and C. pilosa (Stiz.) Elix \& Hale. Then the characteristic features of Canomaculina were adnate to strongly adnate thalli

1. Instituto de Botânica, Caixa Postal 3005, 01061-970 São Paulo, SP, Brazil

2. Autor para correspondência: adrianospielmann@yahoo.com.br 
(Hale 1976), typically narrow lobes, (1-) 2-4 (-5) $\mathrm{mm}$, and dimorphic rhizines (Elix \& Hale 1987).

Some years later, Kurokawa (1991a) proposed Rimeliella Kurok., to embrace several species formerly classified within Parmotrema, with adnate to loosely adnate thalli, wide lobes (5-15 $\mathrm{mm}$ ) and dimorphic rhizines. Afterwards, Elix (1997) concluded that lobe's width (narrow in Canomaculina, wide in Rimeliella) was not enough to distinguish the two genera, and since both have dimorphic rhizines, he synonymized Rimeliella under Canomaculina.

Rimelia was proposed by Hale \& Fletcher (1990), based on Parmelia section Hypotrachyna *Irregularis (Vainio 1890). It shares several features with Parmotrema, but differs by a combination of characters: upper surface reticulate cracked, cilia almost always present [lacking only in Rimelia ruminata (Zahlbr.) Hale \& Fletcher], lower surface generally rhizinate to margins (with several exceptions), and rhizines often squarrose (Hale $\&$ Fletcher 1990). However, there are species of Parmotrema with reticular maculae (particularly those with salazinic acid) and rhizinate to the margin, as well as species of Rimelia with a wide bare zone on lobes undersurface, so that the distinction of the genera is, in many instances, difficult. Canomaculina Elix \& Hale, by their turn, has species with broad or narrow lobes, ciliate, upper surface with effigurate maculae, lower surface rhizinate to the margins and dimorphic rhizines (Elix 1997).

Previously we treated Canomaculina and Rimelia separately (Spielmann \& Marcelli 2008), but here they are included under Parmotrema, following the proposed circumscription of Blanco et al. (2005). Although few Parmotrema s. str. were included in this paper, $P$. perforatum, the type of the genus, was shown to be closely related to the others representatives. Maybe future studies, based on a higher amount of species, mainly from South America, could change this picture.

Nowadays about 350 species of Parmotrema s.1. are known (Blanco et al.2005), although much more remain to be discovered or correctly delimited, based on modern taxonomic features.

\section{Material and methods}

Detailed description and maps of the studied area, material and methods employed and considerations on general morphology can be found in Spielmann (2005) and Spielmann \& Marcelli (2008). Spot tests were performed by the use of $\mathrm{K}$ (potassium hydroxide), $\mathrm{C}$ (sodium hypochlorite) and $\mathrm{P}$ (paraphenylenediamine). TLC analysis followed Huneck \& Yoshimura (1996), Orange et al. (2001) and Bungartz (2001). Several specimens were collected "on the roadside". So this information is not repeated in the Specimens examined. Just different data were kept. Brazilian States abbreviations follow Marcelli (1998).

\section{Results and Discussion}

In the following flora we tried to put in evidence old and modern generic concepts, both in the key and in the disposition of the species, to facilitate the identification. The figures, however, are arranged in alphabetical order.

Key to Parmotrema from Serra Geral slopes in central Rio Grande do Sul State, Brazil

1. Upper surface clearly maculate, underside rhizinate up to the margin or more rarely nude

2. Maculae effigurate, cilia generally short, tapered and thick, underside often brown throughout or black only in the center (formerly Canomaculina; Group I below)

3. Thallus with soredia

4. Medulla $\mathrm{K}-, \mathrm{KC}+$ reddish, $\mathrm{P}-$ (norlobaridone) P. conferendum

4. Medulla $\mathrm{K}+$ yellow, $\mathrm{KC}-, \mathrm{P}+$ orange (stictic acid) P. muelleri

3. Thallus without soredia

6. Medulla $\mathrm{K}+$ yellow $\rightarrow$ red (salazinic acid) P. subcaperatum

6. Medulla $\mathrm{K}-$

7. Medulla $\mathrm{KC}+$ rose (norlobaridone) P. recipiendum

7. Medulla KC- (fatty acids) P. consors

2. Maculae reticulate, cilia long and thin, underside black (formerly Rimelia; Group III below) 
8. Thallus with soredia or pustules

9. Thallus with soredia raised from pustules and soralia; medulla UV+ yellow-orange (lichexanthone) P. diffractaicum

9. Thallus with soredia raised only from soralia; medulla UV-

10. Medulla $\mathrm{K}+$ yellow $\rightarrow$ red (salazinic acid) P. clavuliferum

10. Medulla K-

11. Medulla $\mathrm{KC}+$ reddish rose (norlobaridone)

P. commensuratum

11. Medulla KC- (caperatic acid) P. simulans

8. Thallus without soredia or pustules

12. Medulla $\mathrm{K}+$ yellow $\rightarrow$ red, $\mathrm{KC}-$ (salazinic acid) P. cetratum

12. Medulla $\mathrm{K}-, \mathrm{KC}+$ rose or red (norlobaridone)

P. homotomum

1. Upper surface emaculate (rarely inconspicuously maculate), underside with a distinct bare zone around the margins (Parmotrema s. str. ; Group II below)

13. Thallus with soredia, isidia or pustules

14. Thallus with isidia (occasionally disintegrating into soredia with the age)

15. Lobes eciliate; medulla $\mathrm{C}+$ red (lecanoric acid)

P. tinctorum

15. Lobes ciliate; medulla $\mathrm{C}-$

16. Medulla $\mathrm{K}+$ yellow, $\mathrm{KC}+$ reddish, $\mathrm{UV}-$ (stictic acid and norlobaridone) P. internexum

16. Medulla $\mathrm{K}-, \mathrm{KC}+$ rose $\rightarrow$ quickly orange, $\mathrm{UV}+$ greenish blue (alectoronic acid) .. P. mellissii

14. Thallus with soredia or pustules

17. Thallus with pustules, soredia present or lacking

18. Lobes eciliate P. alidactylatum

18. Lobes ciliate

19. Medulla yellowish to orange

P. flavomedullosum

19. Medulla white

20. Medulla K+ yellow, UV- (stictic acid) P. bangii

20. Medulla $\mathrm{K}+$ yellow $\rightarrow$ red (salazinic acid), $\mathrm{UV}+$ yellow-orange (lichexanthone) P. spinibarbe

17. Thallus without pustules, soredia always present

21. Lobes eciliate

22. Medulla C+ red (lecanoric acid)

P. austrosinense

22. Medulla $\mathrm{C}-$

23. Medulla $\mathrm{K}+$ yellow (atranorin)

P. mordenii

23. Medulla $\mathrm{K}-$ P. praesorediosum

21. Lobes ciliate

24. Medulla $\mathrm{K}+$ yellow, $\mathrm{P}+$ orange (stictic acid) P. perlatum

24. Medulla $\mathrm{K}-, \mathrm{P}-$

25. Medulla $\mathrm{KC}+$ rose or reddish, $\mathrm{UV}-$ (gyrophoric acid)

26. Thallus membranaceous to subcoriaceous, of medium size (8.5-11.0 $\mathrm{cm}$ in diameter); conidia sublageniform, 5.0-9.0 $\mu \mathrm{m}$ long ........ P. sancti-angeli

26. Thallus subcoriaceous, robust (20-28 cm in diameter); conidia filiform, 8.0-12.5 $\mu \mathrm{m}$ long

P. indicum

25. Medulla $\mathrm{KC}+$ rose $\rightarrow$ quickly orange, $\mathrm{UV}+$ greenish blue

27. Soredia often rising from arbuscular structures like a cauliflower; with an orange medullar pigment $\mathrm{K}+$ red (unknown anthraquinone) present at the soralia and lobe apices P. hypomiltoides

27. Soredia rising from marginal to submarginal soralia and usually linear; pigment orange $\mathrm{K}+$ red (skyrin) present only in the older parts, next to the lower cortex P. rampoddense

13. Thallus without vegetative propagules

28. Medulla $\mathrm{K}+$ yellow or $\mathrm{K}+$ yellow $\rightarrow$ red 
29. Medulla $\mathrm{K}+$ yellow $\rightarrow$ red (salazinic acid) P. mantiqueirense

29. Medulla $\mathrm{K}+$ yellow (stictic acid) P. eciliatum

28. Medulla K-

30. Medulla KC-, UV- (protopraesorediosic acid) P. melanothrix

30. Medulla $\mathrm{KC}+$ rose $\rightarrow$ quickly orange, $\mathrm{UV}+$ greenish blue (alectoronic acid)

31. Lower surface with a white margin; conidia unciform 4.0-5.5 $\mu \mathrm{m}$ long

P. subrugatum

31. Lower surface with a brown margin; conidia bacillar to filiform 6.0-12.5 $\mu \mathrm{m}$ long P.wainioi

Group I - Canomaculina-like lichens (species with dimorphic rhizines, effigurate or punctiform maculae, and rhizinate up to the margin, belonging to Canomaculina sensu Elix 1997)

This group of species is distinguished by the usually thickened, furcated and spiky cilia, maculate effigurate upper cortex, lower surface often brown and usually rhizinate up to the margin and the presence of dimorphic rhizines, the later feature being the more distinctive one.

To make easier the comparison between the known species of canomaculinoid lichens, a table (1) was created, with data obtained from literature: Adler \& Elix (1987), Canêz (2005), Chen et al. (2003), Eliasaro (2001), Elix (1997), Ferraro \& Elix (1993, 2000), Fleig (1997), Hale (1959, 1965, 1976, 1977, 1986), Krog (1974), Krog \& Swinscow (1981), Kurokawa (1974, 1991a), Kurokawa \& Lai (2001), Marcelli \& Ribeiro (2002), Mata García (1994), Ribeiro (1998) and Swinscow \& Krog (1988).

Parmotrema conferendum Hale, Mycotaxon 5(2): 433. 1977 = Rimeliella conferenda (Hale) Kurok., Annals of the Tsukuba Botanical Garden 10: 4. $1991 \equiv$ Canomaculina conferenda (Hale) Elix, Mycotaxon 65: 476. 1997. Type: VENEZUELA. ESTADO DE MÉrIDA: El Valle, on rocks along stream, 2,600 m alt., 8-II-1974, M.E. Hale 43291 (holotype US), fide Hale (1977).

Figure 9

Thallus olivaceous gray, brownish in herbarium, lobate, membranaceous to subcoriaceous, loosely adnate, saxicolous, $6.5-13.5 \mathrm{~cm}$ broad. Lobes irregularly branched, laterally overlapping to contiguous, 5-15 $\mathrm{mm}$ wide, surface smooth to irregular, lustrous, becoming rugose and scrobiculate in the center; apical zone plane to subconcave, margin plane to ascendant or revolute, crenate to incise-crenate (sublacinulate); marginal zone plane to ascendant or revolute, margin undulate, crenate to lacinulate, sometimes involute. Lacinules simple, $0.5-$ $1.0 \times 0.5-2.0 \mathrm{~mm}$, marginal, plane to canaliculated, evenly distributed, apex rounded or truncate. Maculae weak to distinct, punctiform, irregular or reticulate, laminal. Cilia black, simple to furcated or sometimes squarrose, $0.10-1.20 \times 0.02-0.10 \mathrm{~mm}$, frequent, evenly distributed. Pustules and isidia absent. Soralia dirty white, usually capitate, coalescing at maturity, marginal to submarginal, turning the lateral margin involute; soredia subgranular. Medulla white. Lower surface pale brown, lustrous, sometimes strongly veined and depressed, rugose; marginal zone pale brown, sometimes white variegated, lustrous, 0.5$1.0 \mathrm{~mm}$ wide, with short or immature rhizines, bare, smooth, rugose or veined, without a sharp limit. Rhizines black to dark brown, dimorphic, the short ones simple, straight or curly, $0.10-0.50 \times 0.01-$ $0.05 \mathrm{~mm}$, abundant, evenly distributed, the long ones usually simple, sometimes furcated or irregularly branched, $0.50-3.00 \times 0.05-0.20 \mathrm{~mm}$, frequent, in disperse groupings. Apothecia unknown. Pycnidia submarginal, little conspicuous, without prominent margin, ostiole black. Conidia filiform, straight or arcuate, $10-16 \times$ ca. $1 \mu \mathrm{m}$.

Color tests: cortex $\mathrm{K}+$ yellow, $\mathrm{UV}-$; medulla $\mathrm{K}-$, $\mathrm{C}-$ or $\mathrm{C}+$ rose, $\mathrm{KC}+$ reddish, $\mathrm{P}-, \mathrm{UV}-$.

TLC: atranorin, norlobaridone, loxodin and unidentified fatty acids.

Distribution: Africa (Winnem 1975), North America (Esslinger 2008) and South America (Hale 1977). In South America it is known to Argentina (Hale 1977, Calvelo \& Liberatore 2002), Brazil (Marcelli 2004), Uruguay (Osorio 2003) and Venezuela (Hale 1977). In Brazil it was recorded to PR (Eliasaro \& Donha 2003) and RS (Spielmann 2006).

Specimens examined: BRAZIL. Rio GRANDE DO SUL:

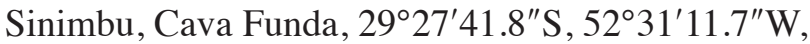


$500 \mathrm{~m}$ alt., 4-II-2003, A.A. Spielmann 24 (SP); idem, $29^{\circ} 27^{\prime} 33.4^{\prime \prime} \mathrm{S}, 52^{\circ} 31^{\prime} 05.1^{\prime \prime} \mathrm{W}, 520$ m alt., with mosses, 5-I-2004, A.A. Spielmann \& L.S. Canêz 668 (SP); idem, Linha Almeida, $29^{\circ} 23^{\prime} 20.2^{\prime \prime} \mathrm{S}, 52^{\circ} 30^{\prime} 21.9^{\prime \prime} \mathrm{W}$, 5-I-2004, A.A. Spielmann \& L.S. Canêz 1297 (SP).

Parmotrema conferendum is distinguished by the usually capitate, marginal to submarginal soralia, and medulla with norlobaridone and loxodin $(\mathrm{K}-$, $\mathrm{KC}+$ reddish). The morphologically similar species differ mostly in chemical constituents (table 1): $P$. subsumptum has salazinic and consalazinic acids, reacting $\mathrm{K}+$ yellow $\rightarrow$ blood red (Fleig 1997), and $P$. reitzii Hale produces salazinic acid and norlobaridone (Hale 1977), reacting $\mathrm{K}+$ yellow $\rightarrow$ blood red and $\mathrm{KC}+$ reddish. This species was placed as synonym of Rimeliella conferenda by Kurokawa (1991a), and as synonym of Rimeliella subsumpta by Fleig (1997). However, Elix (1997) accepted P. reitzii as distinct, an opinion kept here. Parmotrema larense López-Figueiras has, in addition to norlobaridone, lichexanthone in the medulla (Mata García 1994), being UV+ yellow-orange.

The specimen A.A. Spielmann \& L.S. Canêz 668 (SP) has the lower surface strongly veined and sometimes depressed, as well as a white variegated margin. All specimens were found growing on the roadsides, in open places.

Parmotrema consors (Nyl.) Krog \& Swinscow, The Lichenologist 15(2): 129.1983 = Parmelia consors Nyl., Flora 68: 613. 1885 = Canomaculina consors (Nyl.) Elix \& Hale, Mycotaxon 29: 239. 1987. Type: BRAZIL. Minas GeRAIs: Weddell (lectotype selected by Hale 1976, H-NYL35277), fide Hale (1976).

Figure 10

Thallus greenish gray, lobate, adnate, corticicolous or saxicolous, $8-20 \mathrm{~cm}$ broad. Lobes irregularly branched, laterally overlapping, 2-15 mm wide, surface smooth to rugose and scrobiculate, usually pruinose, becoming strongly rugose in the center; margin smooth to incise-crenate (sublacinulate). Lacinules, pustules soredia and isidia absent. Maculae distinct, punctiform to irregular, laminal. Cilia black, simple to furcated or irregularly branched, spiked and robust or slender, 0.10$3.00 \times 0.05-0.20 \mathrm{~mm}$, usually turned downwards, abundant, evenly distributed. Medulla white. Lower surface black, lustrous, smooth to rugose; marginal zone brown, lustrous, 1-3 mm wide, rhizinate, with attenuate limit, smooth to papillate. Rhizines black, simple to irregularly branched, $0.20-3.00$ $\times 0.02-0.30 \mathrm{~mm}$, dimorphism not always evident, but when discernible the short rhizines abundant and evenly distributed, the larger ones frequent and assembled. Apothecia concave to urceolate, 1.5$9.0 \mathrm{~mm}$ in diameter, adnate to substipitate, laminal, margin smooth to crenate, amphithecium smooth, disc brown, perforate at maturity; epithecium 3-8 $\mu \mathrm{m}$; hymenium 35-60 $\mu \mathrm{m}$; subhymenium 15-30 $\mu \mathrm{m}$; ascospores ellipsoid, 11.0-16.5 × 7.0-10.0 $\mu \mathrm{m}$, episporium 1.0-1.5 $\mu \mathrm{m}$. Pycnidia laminal to submarginal, conspicuous, usually with prominent margin, ostiole black; conidia bacillar to filiform, straight or curved, 7-15 × ca. $1 \mu \mathrm{m}$.

Color tests: cortex $\mathrm{K}+$ yellow, $\mathrm{UV}-$; medulla $\mathrm{K}-, \mathrm{C}-$, $\mathrm{KC}-, \mathrm{P}-, \mathrm{UV}-$.

TLC: atranorin and an unidentified fatty acid.

Distribution: Oceania (Elix 1994) and South America (Hale 1976). In South America it is known to Argentina (Osorio 1970d, 1976; Hale 1976; Adler 1992; Calvelo \& Liberatore 2002), Brazil (Zahlbruckner 1930, Hale 1976, Marcelli 2004), Paraguay (Hale 1976), Uruguay (Osorio 1970b/c, 1972, 1992a; Hale 1976) and Venezuela (Feuerer 2005). In Brazil it was recorded to MG (Hale 1976, Ribeiro 1998), MS (Osorio 1992b), MT (Hale 1976), PR (Osorio 1977b, Eliasaro 2001, Eliasaro \& Adler 2000, Eliasaro \& Donha 2003), RJ (Hale 1976), RS (Spielmann 2006), SC (Hale 1976) and SP (Hale 1976, Marcelli 1991).

Specimens examined: BRAZIL. Rio GRANDE do SuL: Boqueirão do Leão, Linha Sinimbuzinho, Perau da Nega, $29^{\circ} 20^{\prime} 02.2^{\prime \prime} \mathrm{S}, 52^{\circ} 26^{\prime} 27.9^{\prime \prime} \mathrm{W}, 440 \mathrm{~m}$ alt., in the stream's margin and close to the street, in a little shaded place, 24-II-2004, A.A. Spielmann \& L.S. Canêz 1288 (SP); idem, $29^{\circ} 18^{\prime} 81.1^{\prime \prime} \mathrm{S}, 52^{\circ} 26^{\prime} 88.5^{\prime \prime} \mathrm{W}$, on the forest border, 7-IX-2000, L.S. Canêz \& A.A. Spielmann 1384 (HCB); Herveiras, near to "Balneário Tio Juba", shaded place, 6-II-2004, A.A. Spielmann \& L.S. Canêz 690 (SP); Sinimbu, Cava Funda, $29^{\circ} 27^{\prime} 33.4^{\prime \prime} \mathrm{S}, 52^{\circ} 31^{\prime} 05.1^{\prime \prime} \mathrm{W}, 520 \mathrm{~m}$ alt., open place, 5-I-2004, A.A. Spielmann \& L.S. Canêz 665 (SP), A.A. Spielmann \& L.S. Canêz 666 (SP), A.A. Spielmann \& L.S. Canêz 687 (SP), A.A. Spielmann \& L.S. Canêz 1290 (SP), A.A. Spielmann \& L.S. Canêz 1294 (SP), A.A. Spielmann \& L.S. Canêz 1296 (SP), A.A. Spielmann \& L.S. Canêz 1300 (SP), A.A. Spielmann \& L.S. Canêz 1328 (SP). 


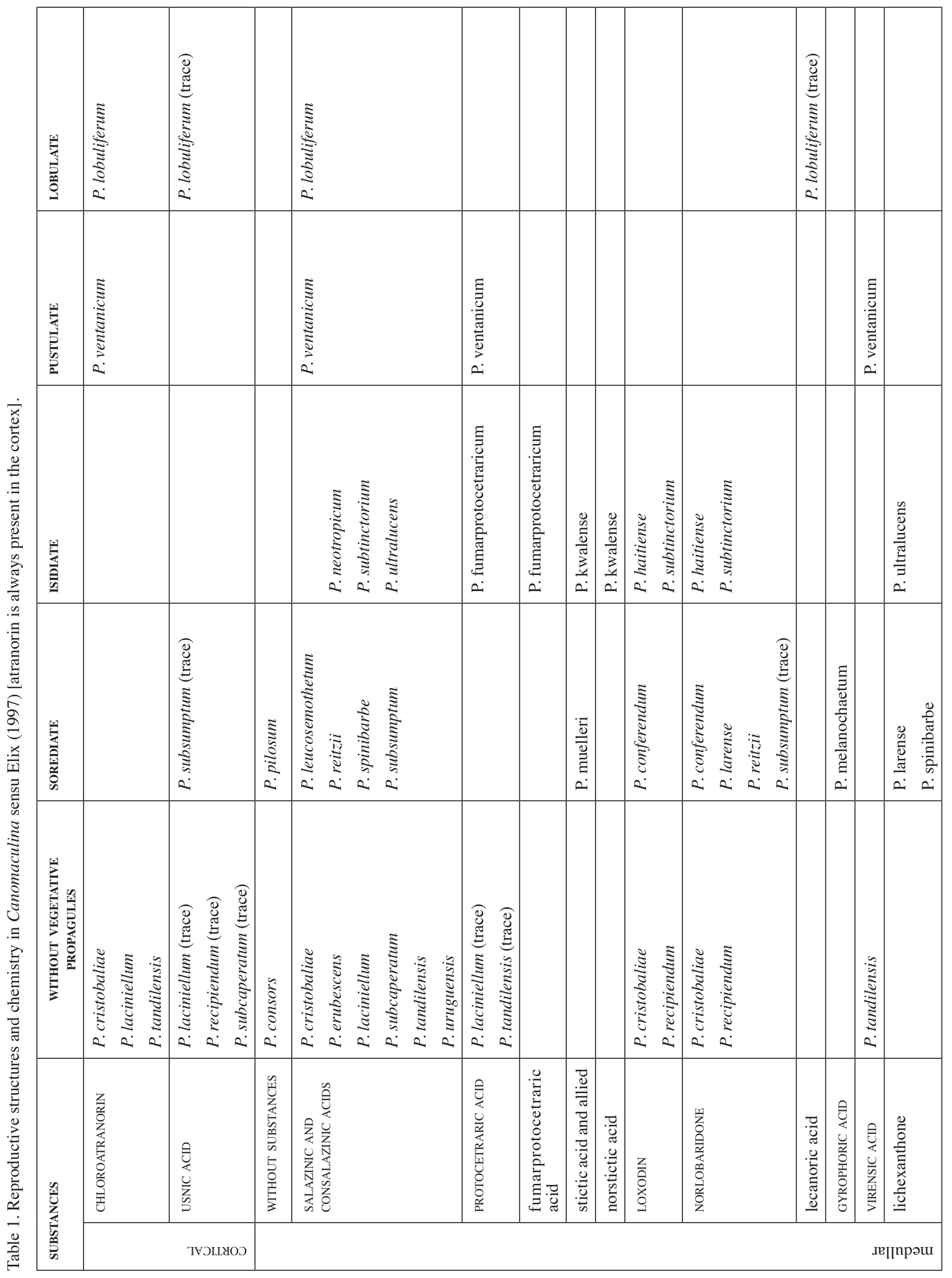


Parmotrema consors is characterized by the absence of vegetative propagules and medulla containing only an unidentified fatty acid (negative reactions). The similar P. pilosum (Stizenb.) Krog $\&$ Swinscow produces soredia, being regarded the sorediate pair of P. consors (Hale 1976).

In the specimens here examined the rhizines range from abundant and covering the entire surface, to frequent, sometimes leaving some parts with few rhizines. As to the dimorphism, it ranges from sharply evident in some specimens to hardly distinguishable in others.

Parmotrema muelleri (Vainio) Blanco, Crespo, Divakar, Elix \& Lumbsch, Mycologia 97(1): 157. $2005 \equiv$ Parmelia muelleri Vainio, Acta Societatis pro Fauna et Flora Fennica 7(1): 49. 1890 三 Canomaculina muelleri (Vainio) Elix \& Hale, Mycotaxon 29: 240. 1987. Type: BRAZIL. MinAS GERAIS: Sítio (nowadays Antônio Carlos), Vainio in Lichenes Brasiliensis exsiccati $\mathrm{n}^{\circ} 948$ (lectotype selected by Hale 1976, TUR, Vainio herbarium $n^{\circ}$ 2677, isolectotypes BM, FH, M, UPS), fide Hale (1976).

Figure 25

Thallus greenish gray to brownish in herbarium, lobate, adnate, subcoriaceous, corticicolous or saxicolous, $11.5-15.0 \mathrm{~cm}$ broad. Lobes irregularly branched, laterally overlapping, 1-11 $\mathrm{mm}$ wide, surface smooth to scrobiculate, becoming rugose and cracked in the center; margin smooth to sublacinulate. Maculae distinct, punctiform to irregular, laminal. Cilia black, simple to furcated or irregularly branched, robust to spiky, $0.20-1.20 \times$ 0.04-0.20 mm, usually downwards turned, frequent, present mainly on the crenae axils. Pustules and isidia absent. Soralia capitate, often coalescing, laminal or frequently reaching the margin; soredia granular. Medulla white. Lower surface black, lustrous, rugose; marginal zone brown, 1.0-3.0 mm wide, with rhizines or nude area up to $1.0 \mathrm{~mm}$ wide, lustrous, with attenuate limit, rugose and papillate. Rhizines black, simple to irregularly branched, 0.10 $2.00 \times 0.02-0.10 \mathrm{~mm}$, abundant, evenly distributed. Apothecia absent [according to Vainio (1890), 2-5 $\mathrm{mm}$ in diameter, cupulate or subpeltate, subssessile, disc testaceous, margin very thin, subentire or sorediate; hymenium ca. $80 \mu \mathrm{m}$; ascospores shortellipsoid to ellipsoid or subglobose, 11-14 $\times$ (7-) 8-10 $\mu \mathrm{m}$ ]. Pycnidia laminal to submarginal, conspicuous, usually with prominent margin, ostiole black; conidia filiform, 10-15 × ca. $1 \mu \mathrm{m}$.

Color tests: cortex $\mathrm{K}+$ yellow, UV-; medulla $\mathrm{K}+$ yellow, $\mathrm{C}-, \mathrm{KC}-, \mathrm{P}+$ orange, $\mathrm{UV}-$.

TLC: atranorin, stictic acid, cryptostictic acid, and an unidentified substance with $\mathrm{Rf} 48$ in solvent $\mathrm{C}$.

Distribution: Asia (Awasthi 1976), North and South America (Hale 1976). In South America it is known to Argentina (Hale 1976, Calvelo \& Liberatore 2002), Brazil (Zahlbruckner 1930, Hale 1976, Marcelli 2004), Peru (Hale 1976), Uruguay (Osorio 1992a) and Venezuela (Hale 1976). In Brazil it was recorded to MG (Hale 1976, Ribeiro 1998), MS (Osorio 1992b), PR (Osorio 1977a, Eliasaro 2001, Eliasaro \& Adler 2000, Eliasaro \& Donha 2003), RS (Spielmann 2006) and SP (Jungbluth 2006).

Specimens examined: BRAZIL. Rio GRANDE do SuL: Herveiras, near to "Balneário Tio Juba", shaded place, 6-II-2004, A.A. Spielmann \& L.S. Canêz 685 (SP); Sinimbu, Cava Funda, 2927'33.4”'S, 52³1'05.1”W, $520 \mathrm{~m}$ alt., open place, 5-I-2004, A.A. Spielmann \& L.S. Canêz 1298 (SP).

Parmotrema muelleri is recognizable by the capitate, laminal soralia and medulla with stictic acid $(\mathrm{K}+$ yellow, $\mathrm{P}+$ orange). The sorediate $P$. pilosum is destitute of demonstrable medullar substances (Hale 1976). Another similar canomaculinoid lichen is P. kwalense (Krog \& Swinscow) Krog $\&$ Swinscow, but it has isidia and in addition to stictic acid, norstictic acid is present (Swinscow \& Krog 1988).

In the specimen A.A. Spielmann \& L.S. Canêz 1298 the rhizines apparently have different sizes, but they surely are stages of development of the same type of rhizines, i.e., they're not dimorphic. This confirms the observations of Hale (1976).

Parmotrema recipiendum (Nyl.) Hale, Phytologia 28(4): $338.1974 \equiv$ Parmelia recipienda Nyl., Flora 68(24): 609. 1885 三 Rimeliella recipienda (Nyl.) Kurok., Annals of the Tsukuba Botanical Garden 10: 7. 1991 ECanomaculina recipienda (Nyl.) Elix, Mycotaxon 65: 477. 1997. Type: BRAZIL. s.l., s.c. (holotype H-NYL35212), fide Kurokawa (1991a).

Figure 29 
Thallus pale grey or brownish in herbarium, lobate, subcoriaceous, loosely adnate, saxicolous, $8.5-14.0 \mathrm{~cm}$ broad. Lobes irregularly branched, laterally overlapping, 5-20 mm wide, surface smooth to scrobiculate, lustrous, becoming scrobiculate, rugose or cracked in the thallus center; apical zone plane to subconcave; lateral marginal zone undulate, plane to ascendant and revolute or involute, margin crenate to incise-crenate (sublacinulate). Lacinules, pustules, soredia and isidia absent. Maculae distinct, punctiform to irregular, laminal. Cilia black, usually simple, sometimes furcated, irregularly branched or squarrose, $0.10-2.00 \times 0.04-0.10 \mathrm{~mm}$, abundant, evenly distributed. Medulla white. Lower surface dark brown, lustrous, smooth to rugose or papillate, sometimes veined; marginal zone brown to pale brown, sometimes white variegated, lustrous to sublustrous, rhizinate or with small rhizines in development, rarely nude (up to $0.5 \mathrm{~mm}$ wide), without a sharp limit, smooth, rugose or papillate. Rhizines usually black, sometimes dark brown, dimorphic, the short ones simple to squarrose or irregularly branched, raised or curly, 0.10-0.50 $\times$ 0.01-0.04 mm, abundant, evenly distributed, the larger ones simple to furcated or irregularly branched, $0.50-2.50 \times 0.04-0.30 \mathrm{~mm}$, frequent, dispersed in groups. Apothecia urceolate, 5-14 mm in diameter, stipitate, laminal to submarginal, margin smooth to crenate, or sometimes dentate or shortdentate, amphithecium maculate, smooth, disc brown, epruinose, perforate; epithecium 7-10 $\mu \mathrm{m}$; hymenium 55-65 $\mu \mathrm{m}$; subhymenium 13-20 $\mu \mathrm{m}$; ascospores ellipsoid to ovoid, $12.5-15.0 \times 6.5-9.0$ $\mu \mathrm{m}$, episporium $0.5-1.0 \mu \mathrm{m}$. Pycnidia submarginal to laminal, conspicuous, usually with prominent margin, ostiole black; conidia filiform straight or arcuate, $10-16 \times$ ca. $1 \mu \mathrm{m}$.

Color tests: cortex $\mathrm{K}+$ yellow, $\mathrm{UV}-$; medulla $\mathrm{K}-, \mathrm{C}-$, $\mathrm{KC}+$ rose, $\mathrm{P}-, \mathrm{UV}-$.

TLC: atranorin, norlobaridone and loxodin.

Distribution: Oceania (Kurokawa 1991a, Elix 1994) and South America (Kurokawa 1991a). In South America it is known to Argentina (Hale 1965, Kurokawa 1991a, Calvelo \& Liberatore 2002), Brazil (Marcelli 2004), Paraguay (Lynge 1914, as Parmelia annae Lynge; Hale 1965), Peru (Hale 1965, Kurokawa 1991a) and Uruguay (Osorio 1980). In Brazil it was recorded to MG (Hale 1965), MT (Lynge 1914, as
Parmelia annae; Kurokawa 1991a), PR (Kurokawa 1991a, Eliasaro 2001, Eliasaro \& Donha 2003), RJ (Kurokawa 1991a), RS (Spielmann 2006) and SP (Hale 1965, Jungbluth 2006).

Specimens examined: BRAZIL. Rio Grande do Sul: Sinimbu, Cava Funda, 29²7'33.4"S, 52 31'05.1”W, $520 \mathrm{~m}$ alt., 5-I-2004, A.A. Spielmann \& L.S. Canêz 696 (SP); Sobradinho, margin of highway RST-481, near the crossroads, $29^{\circ} 24^{\prime} 20.2^{\prime \prime} \mathrm{S}, 5^{\circ} 01^{\prime} 25.9^{\prime \prime} \mathrm{W}, 375 \mathrm{~m}$ alt., 17-VII-2003, A.A. Spielmann 352 (SP).

Parmotrema recipiendum is distinguished by the lack of vegetative propagules and the presence of norlobaridone and loxodin (medulla $\mathrm{K}-, \mathrm{KC}+$ reddish). Parmotrema subcaperatum (Kremp.) Hale is very similar morphologically, so much that the two species were already synonymous (Hale 1965). The last one, however, has salazinic and consalazinic acids (medulla $\mathrm{K}+$ yellow $\rightarrow$ blood red). On the other hand, Parmotrema cristobaliae (Ferraro \& Elix) Blanco, Crespo, Divakar, Elix \& Lumbsch and P. erubescens (Stirton) Krog \& Swinscow have in medulla both norlobaridone and loxodin as well as salazinic acid (Krog \& Swinscow 1981, Ferraro \& Elix 1993). Finally, Parmotrema conferendum has the same chemical pattern of $P$. recipienda, but is a sorediate species.

The specimen A.A.Spielmann 352 (SP) has fertile lobes with several submarginal, grouped apothecia (figure 29), very like the holotype photograph of $P$. recipiendum (Kurokawa 1991a: figure 2). All specimens were collected on the roadsides in open places.

Parmotrema subcaperatum (Kremp.) Hale, Phytologia 28(4): 339. 1974 三 Parmelia subcaperata Kremp., Vidensk. Meddel. Dansk Naturhist. Foren. Kjøbenhavn.25: 10.1874 =Rimeliella subcaperata (Kremp.) Kurok., Annals of the Tsukuba Botanical Garden 10: 7. 1991 @ Canomaculina subcaperata (Nyl.) Elix, Mycotaxon 65: 477. 1997. Type: BRAZIL. Minas Gerais: Caeté, Serra da Piedade, Lagoa Santa [sic?], E. Warming 297 (holotype M), fide Kurokawa (1991a).

Figure 34

Thallus greenish gray to brownish in herbarium, lobate, subcoriaceous, loosely adnate, saxicolous, $6-12 \mathrm{~cm}$ broad. Lobes irregularly branched, laterally overlapping to crowded, 4-20 mm wide, surface smooth to rugose and scrobiculate, lustrous, becoming 
rugose and cracked in the center; apical zone plane to subconcave, margin plane to ascendant or revolute, regular to undulate, crenate to sublacinulate; lateral marginal zone usually ascendant, regular to undulate, sometimes involute, margin crenate to lacinulate. Lacinules simple to furcated or dichotomous, 0.5$2.5 \times 0.5-1.5 \mathrm{~mm}$, plane, apex acute to rounded or truncate, full dispersed in the thallus, lower surface brown or white variegated; maculae weak to distinct, punctiform to irregular, laminal. Cilia black, simple to furcated, sometimes dichotomous or irregularly branched, $0.20-1.20 \times 0.04-0.10 \mathrm{~mm}$, abundant, evenly distributed. Pustules, soredia and isidia absent. Medulla white. Lower surface dark brown to black-brown, especially in the center, lustrous, rugose; marginal zone brown, sublustrous, 1-2 mm wide, with rhizines or rarely nude up to $1 \mathrm{~mm}$ wide, limit absent, smooth to rugose or sometimes veined. Rhizines black, dimorphic, the short ones 0.10-0.50 $\times$ 0.01-0.03 mm, straight or curly, simple, abundant, evenly distributed, the larger ones $0.40-3.00 \times$ $0.05-0.30 \mathrm{~mm}$, simple to furcated or irregularly branched, frequent. Apothecia urceolate, 1-7 mm in diameter, stipitate, laminal to submarginal, margin smooth to crenate or incise, amphithecium smooth, disc epruinose, perforate; epithecium 7-10 $\mu \mathrm{m}$; hymenium 40-50 $\mu \mathrm{m}$; subhymenium 13-20 $\mu \mathrm{m}$; ascospores ellipsoid, 11-14 × 7.5-9.0 $\mu \mathrm{m}$, episporium 0.5-1.0 $\mu \mathrm{m}$. Pycnidia submarginal to laminal, conspicuous, usually with prominent margin, ostiole black; conidia bacilliform to filiform, straight or arcuate, 8.5-15.0 $\times$ ca. $1.0 \mu \mathrm{m}$.

Color tests: cortex $\mathrm{K}+$ yellow, UV-; medulla $\mathrm{K}+$ yellow $\rightarrow$ red, $\mathrm{C}+$ slowly yellowish, $\mathrm{KC}+$ orange, $\mathrm{P}+$ yellow $\rightarrow$ orange, $\mathrm{UV}-$.

TLC: atranorin, salazinic and consalazinic acids.

Distribution: Oceania and South America (Kurokawa 1991a). In South America it is known to Argentina (Calvelo \& Liberatore 2002), Brazil (Zahlbruckner 1930, Kurokawa 1991a, Marcelli 2004), Paraguay (Osorio 1970a), Uruguay (Osorio 1972) and Venezuela (Vareschi 1973). In Brazil it was recorded to MG (Kurokawa 1991a), MS (Osorio 1992b), PR (Osorio 1977b, Kurokawa 1991a), RJ (Kurokawa 1991a), RS (Spielmann 2006) and SP (Kurokawa 1991a).

Specimens examined: BRAZIL. Rio GRANDE DO SUL: Sinimbu, Cava Funda, 29²7'41.8'’S, 52 31'11.7'”W, $500 \mathrm{~m}$ alt., open place, 4-II-2003, A.A. Spielmann 74
(SP); idem, 29²7’33.4”S, 52³1'05.1”W, 520 m alt., open place, 5-I-2004, A.A. Spielmann \& L.S. Canêz 710 (SP), A.A. Spielmann \& L.S. Canêz 976 (SP), A.A. Spielmann \& L.S. Canêz 1295 (SP).

Parmotrema subcaperatum is distinguished by the absence of vegetative propagules, medulla with salazinic $(\mathrm{K}+$ yellow $\rightarrow$ red) and the dark brown lower surface. The similar $P$. recipiendum presents just norlobaridone and loxodin (medulla $\mathrm{K}-, \mathrm{KC}+$ reddish) while P. reparatum (Stirton) Blanco, Crespo, Divakar, Elix \& Lumbsch has a distinct black lower surface (Kurokawa 2001).

Kurokawa (1991a) and Fleig (1997) reported the presence of usnic acid in P. subcaperatum. This substance was not found in this study or by Eliasaro (2001) to specimens from Paraná State.

It's interesting to note that both Hale (1965), Kurokawa (1991a) and Fleig (1997) regarded Parmelia imperforata Nyl. as synonym of $P$. subcaperatum. However, according to Zahlbruckner (1909), P. imperforata (as suggested by the name) has imperforate apothecia, and conidia 10-12 $\mu \mathrm{m}$ long, while $P$. subcaperatum has perforate apothecia slightly longer conidia, $8.5-15 \mu \mathrm{m}$ long.

Actually P. subcaperatum is part of a complex of species, which is being studied through the types and will be published elsewhere (Spielmann \& Marcelli, unpublished data).

Group II - Parmotrema-like lichens (Species without dimorphic rhizines and rarely maculate, with a broad naked rim below, belonging to Parmotrema s. str.)

Parmotrema s. str. is characterized by the generally broad and loosely adnate to adnate thalli, relatively wide lobes, lower surface often with a wide bare zone along the margins and rhizines from simple to furcated or irregularly branched, but never dimorphic (Elix 1993).

To facilitate the comparison among the species of Parmotrema s. str. found, the main morphological and chemical data were summarized in the table 2.

In some species of Parmotrema the rhizines reach the margin, mainly in the form of "rhizinal papillae" (Awasthi 1976) or "rhizines in development" (Fleig 1997). Of the species here dealt with, Parmotrema internexum shows this feature.

Parmotrema alidactylatum Estrabou \& Adler, Mycotaxon 66: 132. 1998. Type: ARGENTINA. Córdoba: Departamento Sobremonte, Cerro 


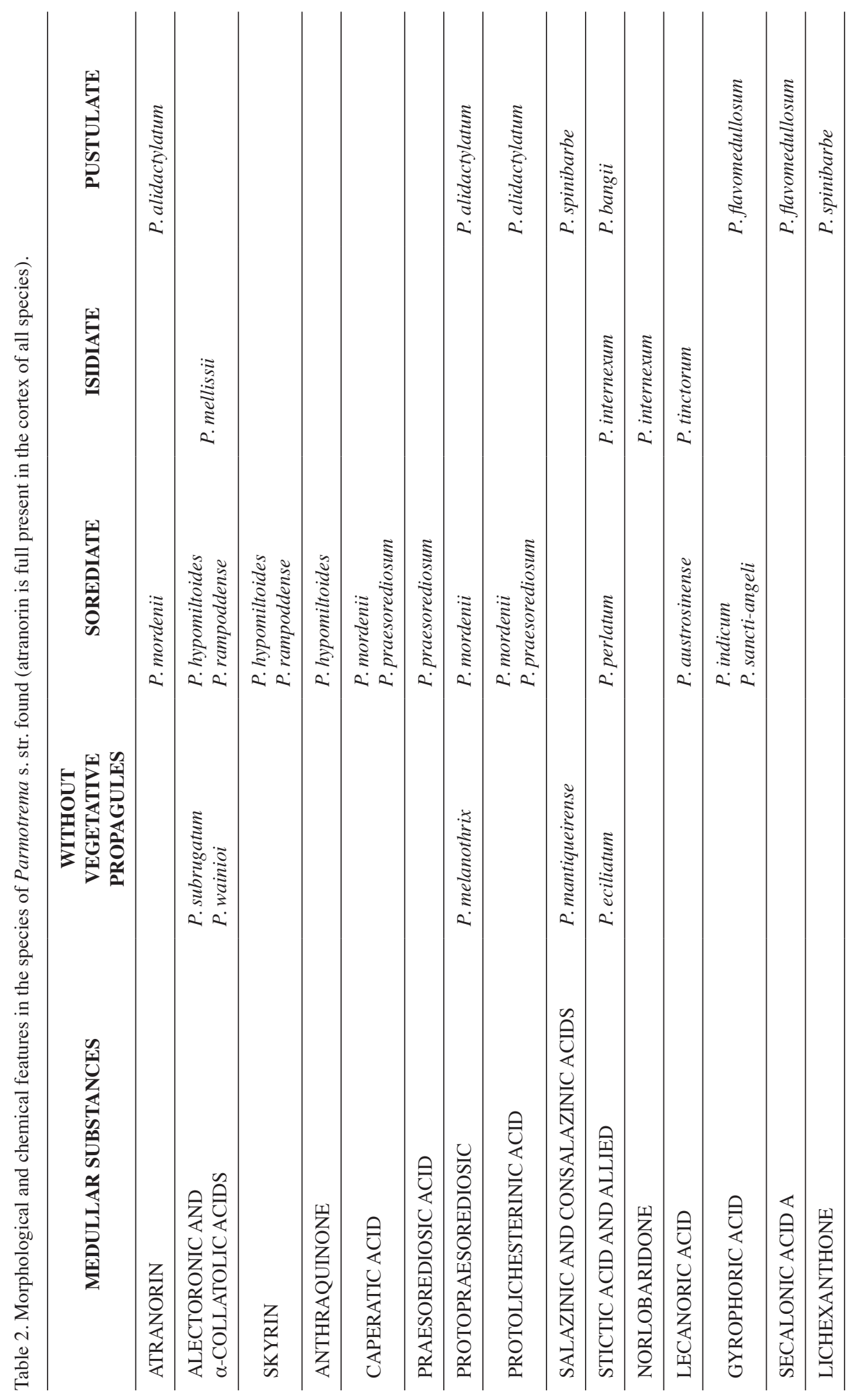


Colorado, 3008'S, 645' 'W, on granite, V-1995, Estrabou (holotype BAFC37877, isotypes BM, CANB, H, O, S, TUR, Estrabou Herbarium 648), fide Estrabou \& Adler (1998).

Figure 1

Thallus pale gray, lobate, membranaceous, loosely adnate, saxicolous, $10 \mathrm{~cm}$ broad. Lobes irregularly branched, laterally overlapping, 3.5-8.0 $\mathrm{mm}$ wide, surface smooth to lightly rugose, opaque to sublustrous, becoming rugose and cracked; apical zone subconcave, margin undulate, entire to broadly crenate, plane or slightly involute; lateral marginal zone undulate, plane or ascendant and involute, margin entire to crenate. Lacinules, maculae, cilia and isidia absent. Pustules simple, short-claviform or irregular, marginal, submarginal or laminal, more abundant in the proximal areas, with a lax medulla, becoming sorediose or not, arising from wrinkles or from capitate structures, often starting as black points in the thallus. Soredia granular, coming from pustules. Medulla white. Lower surface black, lustrous, smooth or more often rugose; marginal zone pale brown or ochraceous, nude or with few rhizines, smooth to papillate or sometimes rugose, opaque to sublustrous, with a sharp limit, 2-4 mm wide. Rhizines black or concolor to the marginal zone, simple or branched, sometimes with the apex flatted or coalescing in the distal areas, $0.20-0.70$ $\times 0.05-0.10 \mathrm{~mm}$, dispersed in groups, frequent. Apothecia and pycnidia unknown.

Color tests: cortex $\mathrm{K}+$ yellow, $\mathrm{UV}-$; medulla $\mathrm{K}+$ yellow, $\mathrm{C}-, \mathrm{KC}-$, P-, UV-.

TLC: atranorin (cortex and medulla), protolichesterinic acid and protopraesorediosic acid.

Distribution: Argentina (Calvelo \& Liberatore 2002).

Specimens examined: BRAZIL. Rio Grande do Sul: Boqueirão do Leão, Linha Sinimbuzinho, Perau da Nega, 29²0'02.2”S, 52 26'27.9”'W, $440 \mathrm{~m}$ alt., left side of the stream, open place, 23-II-2004, A.A. Spielmann \& L.S. Canêz 1205 (SP).

Parmotrema alidactylatum is characterized by the adnate and eciliate thallus with pustules, and the presence of atranorin in the medulla ( $\mathrm{K}+$ yellow). Parmotrema soredioaliphaticum Estrabou \& Adler is very close, but its pustules become sorediose (Estrabou \& Adler 1998). This subtle difference could place $P$. soredioaliphaticum in the synonymy of $P$. alidactylatum (a hypothesis admitted by Estrabou \& Adler 1998). In fact, the only specimen described here show some sorediate pustules. Additional collections from Argentina and Brazil, together with the study of the types, could contribute to this question.

We are naming here the structures of this lichen as pustules, while in the original concept Estrabou \& Adler (1998) called them dactyls. These terms are not clearly delimited in the current literature, and in this respect, there are two other species morphologically close to P. alidactylatum: P. tsavoense (Krog \& Swinscow) Krog \& Swinscow and P. dactylosum Fleig. The first one has physodic acid (medulla KC+ purple), oxyphysodic acid, and filiform conidia with 18-20 um long (Krog \& Swinscow 1981, Swinscow \& Krog 1988), while P. dactylosum produces caperatic acid and unidentified fatty acids, the conidia being sublageniform to almost bifusiform, 5.0-7.5 um long (Fleig 1999).

Parmotrema austrosinense (Zahlbr.) Hale, Phytologia 28(4): 335.1974 = Parmelia austrosinensis Zahlbr., Symbolae Sinicae 3: 192. 1930. Type: CHINA. Kweitschou: Gwanyinschen near Guiyang, Setschwan, Handel-Mazzetti 10580 (lectotype BPI, selected by Hale 1959, isosyntypes BPI), fide Hale (1959).

Figure 2

Thallus pale greenish gray, lobate, loosely adnate, membranaceous to subcoriaceous in some places, saxicolous, $11 \mathrm{~cm}$ broad. Lobes irregularly branched, laterally overlapping, 3.0-7.5(-9.0) $\mathrm{mm}$ wide, surface smooth, opaque to sublustrous, becoming rugose and cracked in the center; apical zone plane to subconcave, margin little to strongly undulate, usually ascendant, smooth to crenate; lateral marginal zone little or strongly undulate, ascendant, margin entire. Lacinules, pustules, isidia and cilia absent. Maculae weak. Soralia white or with black points, marginal, linear interrupted, lightly wider in the older parts; soredia farinose. Medulla white. Lower surface black, opaque, rugose; marginal zone brown or white variegated, lustrous, 2-10 mm wide, with weak to sharp limit, smooth to usually rugose. Rhizines black to concolor with the lower surface, usually simple, $0.2-0.5 \times$ 0.1-0.3 mm, few, dispersed in groups. Apothecia absent [according with Hale (1965), substipitate, to $10 \mathrm{~mm}$. in diameter, amphithecium maculate, 
sparsely sorediate, disc perforate; hymenium $75 \mu \mathrm{m}$; ascospores 10-16 × 6-10 $\mu \mathrm{m}$, episporium 1,5 $\mu \mathrm{m}]$. Pycnidia submarginal, conspicuous, with or without prominent margin, ostiole black; conidia filiform, (11.0-) 14.0-16.0 (-17.5) × ca. $0.5 \mu \mathrm{m}$.

Color tests: cortex $\mathrm{K}+$ yellow, $\mathrm{UV}-$; medulla $\mathrm{K}-, \mathrm{C}+$ red, $\mathrm{KC}+$ red, $\mathrm{P}-$, UV-

TLC: atranorin, lecanoric acid.

Distribution: Oceania (Feuerer 2005), Australia (Hale 1965), Asia (Zahlbruckner 1932, Hale 1965), Europe (Hale 1965), Africa (Hale 1965, Swinscow \& Krog 1988) and Americas (Hale 1965). In South America it is known to Argentina (Hale 1965, Calvelo \& Liberatore 2002), Brazil (Marcelli 2004), Colombia (Hale 1965), Paraguay (Hale 1959), Uruguay (Hale 1965, Osorio 1992a) and Venezuela (Hale 1965, Vareschi 1973); in Brazil it was recorded to MG (Ribeiro 1998), MS (Osorio 1992b), PR (Eliasaro 2001), RS (Spielmann 2006) and SP (Marcelli 1991, Ribeiro 1998).

Specimens examined: BRAZIL. Rio GRANDE do SuL: Sinimbu, Cava Funda, 2927'41.8'S, 52³1'11.7'W, $500 \mathrm{~m}$ alt., 5-I-2004, A.A. Spielmann \& L.S. Canêz 1088 (SP).

Parmotrema austrosinense is distinguished by the linear soralia, the lacking cilia, and the presence of lecanoric acid (medulla $\mathrm{C}+$ red) and atranorin (cortex greenish gray, $\mathrm{K}+$ yellow). The white variegated lower surface also seems to be a constant feature, agreeing with the literature (Hale 1965, 1979, Krog \& Swinscow 1981, Hale \& Cole 1988, Elix 1994, Fleig 1997, Brodo et al. 2001).

Parmotrema defectum (Hale) Hale share the above presented features, but has an adnate to strongly appressed thallus, and lightly shorter conidia, 10-12 um long (Krog \& Swinscow 1981) [yet Swinscow \& Krog (1988) gave a different size: 16-20 (24) um long]. It is the sorediate counterpart of $P$. soyauxii (Müll. Arg.) Hale, while $P$. austrosinense is the counterpart of $P$. andinum (Müll. Arg.) Hale (Hale 1965, Swinscow \& Krog 1988).

Two other similar sorediate species, $P$. cooperi (Steiner \& Zahlbr.) Sérus. and $P$. sancti-angeli (Lynge) Hale, can be easily identified by the presence of marginal cilia (Hale 1965).

The illustrations of $P$. austrosinense in Tavares (1945, as Parmelia meridionalis), Awasthi (1976),
Hale (1979), Hale \& Cole (1988) and Brodo et al. (2001) are very alike the specimen here studied. Notwithstanding, the picture from Swinscow \& Krog (1988) seems to suggest the presence of capitate, sorediate structures.

It is interesting to note that Hale (1965) and Awasthi (1976) asserted that $P$. austrosinense has "widely perforated" apothecia, while Krog \& Swinscow (1981), Elix (1994) and Nash \& Elix (2002a) stated that the apothecia vary from perforate to imperforate, unfortunately not specifying if in the same thalli or not. Species pairs in which one counterpart has perforate apothecia and the other not are, as far as we are aware, unreported in Parmotrema. If both $P$. austrosinense and $P$. andinum present perforate apothecia, then the species pair is well defined. Nevertheless, if a "hidden" species, very similar to $P$. austrosinense, with imperforate apothecia, in fact exist, its counterpart would be another one, for example, some of the specimens reported by Awasthi (1976) as Parmelia andina, with apothecia imperforate or perforate in the center. Moreover, there are differences in the soralia and soredia between the authors that describe perforate and imperforate apothecia. Since there are several accepted synonyms in both $P$. austrosinense and $P$. andinum, only a revisionary work could solve this question, because more than one taxon seems to be implied.

The typification of this species is also a little confused. Firstly, Hale (1965) asserted that the lectotype is located in WU, and the "isotypes" in BPI and W. Elix (1994), Fleig (1997) and Eliasaro (2001) wrote "isolectotypes" instead of isotypes. On the other hand, Fleig (1997) stated that the lectotype is in US, not BPI. As some authors (e.g. Elix 1994, Eliasaro 2001) used "fide Hale 1965", and Hale (1965) sends back to his previous paper, we are here using the data from Hale (1959), who made the typification.

Ribeiro (1998) described the rhizines of Parmotrema austrosinense as "dimorphic, black, simple and dichotomous". With this features, his lichen is more properly a Canomaculina, and deserves further confirmation.

Parmotrema bangii (Vainio) Hale, Phytologia 28(4): 335.1974 = Parmelia bangii Vainio, in Schmidt, Botanisk Tidskrift 29: 104. 1909. Type: BOLIVIA. La Paz, 1891, M. Bang 13 (holotype H-NYL35500), fide Hale (1965). 


\section{Figure 3}

Thallus greenish gray, lobate, membranaceous, loosely adnate, corticicolous, $13.5 \mathrm{~cm}$ broad. Lobes irregularly branched, crowded, 3.5-9.0 mm wide, surface smooth to slightly rugose, opaque to sublustrous, becoming reticulate cracked in the old parts, cortex disintegrating in large submarginal areas and forming sorediate pustules; apical zone plane to subconcave, margin undulate, broadly crenate to sublacinulate; lateral marginal zone undulate, at first imbricate, then ascendant and involute, margin sublacinulate. Lacinules, maculae and isidia absent. Cilia black, simple or rarely with a branched, penicillate apex, 0.50-3.00 × 0.03-0.05 $\mathrm{mm}$, abundant to frequent, present mainly in the lobe axils. Pustules verruciform to capitate, laminal to more commonly submarginal, often coalescing and covering large areas, turning the margins undulate and involute, fragmenting in soredia. Soralia concolor to the thallus, pustular or formed from the disintegration of the cortex, diffuse, coarse, usually laminal; soredia granular. Medulla white. Lower surface black, lustrous, smooth to rugose; marginal zone pale or dark brown, sometimes white variegated or beige under the sorediate areas, or even black in some points, lustrous, nude or with sparse rhizines, 1.5-3.0 mm wide, with an attenuate or sharp limit, smooth, rugose or veined. Rhizines black, simple or branched, $0.50-2.00 \times 0.03-0.05 \mathrm{~mm}$, frequent, evenly distributed. Apothecia absent [according to Vainio (1909), up to $5 \mathrm{~mm}$ in diameter, cupulate, subsessile, imperforate, excipulum smooth or with a few soredioid or isidioid granules, ascospores ellipsoid-oblong, 26-36 × 11-16 $\mu \mathrm{m}$, and episporium 3-4 um (Hale 1965)]. Pycnidia absent [according to Vainio (1909), conidia sub-bifusiform, 5 um long].

Color tests: cortex $\mathrm{K}+$ yellow, UV-; medulla $\mathrm{K}+$ yellow, $\mathrm{C}-, \mathrm{KC}-, \mathrm{P}+$ slowly orange, $\mathrm{UV}-$.

TLC: atranorin, stictic acid, constictic acid, cryptostictic acid, hypoconstictic acid, hypostictic acid, and an unidentified substance similar to rhizocarpic acid.

Distribution: Africa (Østhagen \& Krog 1976, Krog \& Swinscow 1981, Sérusiaux 1984, Swinscow \& Krog 1988) and South America (Hale 1965). In South America it is known to Bolivia (Vainio 1909, Zahlbruckner 1930, Hale 1965, Feuerer et al. 1998), Brazil (Marcelli 2004), Colombia (Hale 1965) and Venezuela (Feuerer 2005).
Specimens examined: BRAZIL. Rio GRANDE do SuL: Boqueirão do Leão, Linha Sinimbuzinho, Perau da Nega, 29²0'02.2'S, 52²6'27.9'W, 440 m alt., open place, 23-II-2004, A.A. Spielmann \& L.S. Canêz 700 (SP).

Parmotrema bangii is characterized by the sorediose pustules and the granular soredia originated from the cortex disintegration, together with the presence of stictic acid (medulla $\mathrm{K}+$ yellow, $\mathrm{P}+$ slowly orange). Parmotrema perlatum is a similar sorediate species, also with stictic acid, but in this species the soralia are linear and marginal, never forming pustules. P. madylinae Fletcher has pustules, but instead of stictic acid, it has protocetraric acid (medulla K-) and shorter ascospores, 23-25 × 14-15 $\mu \mathrm{m}$, episporium $2 \mu \mathrm{m}$ (Hale 1986).

Unfortunately, we were unable to find pycnidia in our specimen. However, it must be noted that Krog \& Swinscow (1981) reported the conidia as being bacillar to filiform, $8-10 \mu \mathrm{m}$ long, so different from that described by Vainio (1909).

Parmotrema eciliatum (Nyl.) Hale, Phytologia 28(4): 336. 1974 = Parmelia crinita Ach. var. eciliata Nyl., Flora 52: 291. 1869. Type: MEXICO. OrIZABA: Bourgeau s.n. (holotype H-NYL35295, isotype P), fide Hale (1965).

Figures 13, 37

Thallus greenish gray, lobate, membranaceous to subcoriaceous, loosely adnate, saxicolous, $12 \mathrm{~cm}$ broad. Lobes irregularly branched, laterally overlapping to crowded, $4.0-8.0 \mathrm{~mm}$ wide, median axis extended to subascendant, surface smooth to irregular, opaque to lustrous, becoming rugose and cracked in the center; apical zone subplane to concave, margin undulate, subplane or ascendant, sometimes involute, crenate to incise-crenate (sublacinulate); lateral marginal zone undulate, suberect to erect, subimbricate and involute. Lacinules, pustules, soredia and isidia absent. Maculae present only close to the apothecia. Cilia black, simple to furcated or sometimes irregularly branched, $0.50-3.00 \times 0.02-$ $0.10 \mathrm{~mm}$, frequent, evenly distributed. Medulla white. Lower surface black, lustrous, rugose; marginal zone brown to beige, narrow $(0.5-2.0 \mathrm{~mm})$ or with large parts white variegated (1-6 mm), lustrous to opaque, nude, smooth to rugose, with a sharp limit. Rhizines black, simple to rarely irregularly branched, $0.20-1.50$ $\times 0.01-0.02 \mathrm{~mm}$ (with two well distinct sizes in some lobes), sometimes twisted or coalescent, or 
slightly prostrate and entangled, abundant, more or less evenly distributed. Apothecia urceolate to patent, 1-13 $\mathrm{mm}$ in diameter, stipitate, laminal to submarginal, base constricted, rugose, margin smooth to dentate, eciliate, amphithecium maculate, strongly rugose, disc brown, imperforate, plane to involute, entire or splitted; ascospores ellipsoid to reniform, 22.5-29.0 (-31.5) × 12.5-16.5 (-19.0) $\mu \mathrm{m}$, episporium $2.5-3.5 \mu \mathrm{m}$. Pycnidia submarginal to laminal, abundant, ostiole black; conidia bacillar to filiform, rarely with a brief apical thickening, 5-9 $\times$ ca. $1 \mu \mathrm{m}$.

Color tests: cortex $\mathrm{K}+$ yellow, $\mathrm{UV}-$; medulla $\mathrm{K}+$ yellow, $\mathrm{C}-, \mathrm{KC}-, \mathrm{P}+$ orange, $\mathrm{UV}-$.

TLC: atranorin, stictic acid, constictic acid, cryptostictic acid and hypostictic acid.

Distribution: Asia (Kurokawa 1991b, Kurokawa \& Lai 2001, Feuerer 2005), Oceania (Elix 1994), Africa (Hale 1965, Krog \& Swinscow 1981, Swinscow \& Krog 1988), North and Central America (Hale 1965, Feuerer 2005) and South America (Hale 1965). In South America, it is known to Argentina (Lynge 1914, Hale 1965, Adler 1992, Calvelo \& Liberatore 2002), Brazil (Hale 1965, Marcelli 2004) and Uruguay (Osorio 1972, 1992a). In Brazil, it was recorded to PR (Eliasaro \& Donha 2003), RJ (Hale 1965) and RS (Spielmann 2006).

Specimens examined: BRAZIL. Rio GRANDE Do SuL: Sobradinho, margin of highway RST-481, near the crossroads, $29^{\circ} 24^{\prime} 20.2^{\prime \prime} \mathrm{S}, 53^{\circ} 01^{\prime} 25.9^{\prime \prime} \mathrm{W}, 375 \mathrm{~m}$ alt., open place, 17-VII-2003, A.A. Spielmann 410 (SP).

Parmotrema eciliatum is distinguished by the ciliate lobes, presence of stictic acid (medulla $\mathrm{K}+$ yellow, $\mathrm{P}+$ orange), apothecia imperforate, and the absence of vegetative propagules. Parmotrema aldabrense (C.W. Dodge) Hale, reported to Africa, sometimes presents stictic acid as an accessory substance to the norstictic acid (Medulla $\mathrm{K}+$ yellow $\rightarrow$ red), his main substance. However, it has perforate apothecia, maculae distinct, ascospores 13-18 × 5-7 um (Hale 1965) and filiform conidia, 12-15 um long (Swinscow \& Krog 1988). Parmotrema preperforatum (W.L. Culb.) Hale, known in the United States, also has norstictic acid and stictic acid, together with perforate apothecia (Culberson 1973), but this is the only information we were able to find about this species, so that we don't know more differences between $P$. aldabrense and $P$. preperforatum, except that one is recorded to Africa and the other to North America. Finally, P. blanchetianum (Müll. Arg.) Kalb, has similar morphology, but produces protocetraric acid instead stictic acid. In the course of the present work we noted that $P$. eciliatum could also be distinguished by the cilia, usually furcated or irregularly branched (figure 37).

Parmotrema flavomedullosum Hale, Mycotaxon 1(2): 110. 1974. Type: BRAZIL. SANTA CATARINA: Campos Novos, Colony Santa Catarina, saxicolous, 9-VIII-1963, R. Reitz \& R.M. Klein 15051 (holotype US), fide Fleig (1997).

Figures 14, 40

Thallus pale grey, lobate, membranaceous to subcoriaceous in some areas, loosely adnate, corticicolous or saxicolous, $15.0-18.5 \mathrm{~cm}$ broad. Lobes irregularly branched, laterally overlapping to crowded, 4-20 mm wide, surface smooth, rugose or with the cortex disintegrating in patches, sublustrous to opaque, becoming rugose in the center; apical zone plane to concave or involute, often curled or apically straighten and, combining with the involution of the lateral margins, assuming the aspect of a " $\mathrm{T}$ " when the lobe is observed from the lower side (figure 40), margin entire to crenate; lateral marginal zone undulate, plane to ascendant and involute, margin entire to crenate or incise-crenate (sublacinulate). Lacinules, maculae and isidia absent. Cilia black, cylindrical or flatted, simple to dichotomous, $0.40-3.00 \times 0.05-0.10 \mathrm{~mm}$, few, present on the axillar crenae, more abundant in some areas than others. Pustules developed from wrinkles, laminal to marginal, present mainly in the apices and lobe margins, breaking up in soredia. Soralia capitate to extensive, marginal to submarginal, approaching the lamina, usually developed from pustules, or sometimes directly from the fragmentation of the surface, commonly causing the " $\mathrm{T}$ " aspect of the lobes; soredia from subgranular to granular, sometimes isidioid and coalescing. Medulla yellow to orange. Lower surface black, lustrous, smooth, rugose or rugose-reticulate; marginal zone brown to beige or chestnut, opaque to lustrous, $1.5-6.0 \mathrm{~mm}$ wide, nude, limit from sharp to attenuate, smooth, papillate, rugose to strongly rugose-reticulate or with veins, usually with cracks. Rhizines black or sometimes with a whitish apex, simple to furcated 
or irregularly branched, $0.20-3.00 \times 0.02-0.10 \mathrm{~mm}$, few to frequent, dispersed in small groups. Apothecia and pycnidia unknown.

Color tests: cortex $\mathrm{K}+$ yellow, UV-; medulla $\mathrm{K}+$ yellow, $\mathrm{C}+$ orange, $\mathrm{KC}+$ yellow, $\mathrm{P}-$ (fading the pigment yellow), UV-.

TLC: atranorin, gyrophoric acid, secalonic acid A and $\mathrm{C}$ and unidentified substance of $\mathrm{Rf} 51$ in solvent $\mathrm{C}$.

Distribution: Known only to South America, where it was reported to Argentina (Hale 1974c), Brazil (Marcelli 2004), Paraguay and Venezuela (Hale 1974c). In Brazil it was recorded to MG (Hale 1974c), MS (Osorio 1992b), PR (Hale 1974c, Eliasaro 2001), SC (Hale 1974c, Fleig 1997) and RS (Spielmann 2006).

Specimens examined: BRAZIL. Rio Grande do Sul: Boqueirão do Leão, Cascata do Gamelão, $29^{\circ} 18^{\prime} 13.7^{\prime \prime} \mathrm{S}, 52^{\circ} 26^{\prime} 51.7^{\prime \prime} \mathrm{W}, 500 \mathrm{~m}$ alt., on the steep slope near the waterfalls, shaded place (inside the forest), 1-II-2004, A.A. Spielmann \& M.A. Sulzbacher 743 (SP); idem, in the right side of the stream, open place, 1-II-2004, A.A. Spielmann \& M.A. Sulzbacher 1037 (SP).

Parmotrema flavomedullosum is recognizable by the ciliate lobes, pustules fragmenting in soredia and the yellow to orange medulla with gyrophoric acid and secalonic acids $\mathrm{A}$ and $\mathrm{C}(\mathrm{K}+$ yellow, $\mathrm{C}+$ orange, $\mathrm{KC}+$ yellow). Some other species of Parmotrema with yellow medulla can be distinguished as follow: $P$. araucariarum (Zahlbr.) Hale has eciliate lobes and the gyrophoric acid absent (Hale 1974c), $P$. endosulphureum (Hillm.) Hale has eciliate lobes and produces isidia instead of soredia (Hale 1974c). Finally, Parmelia elabens Kurok., described in 1974 based on specimens from Paraná State, is regarded a synonym of P. flavomedullosum by Fleig (1997), Hale \& DePriest (1999) and Eliasaro (2001).

Parmotrema hypomiltoides (Vainio) Kurok., Bulletin of the Botanic Gardens of Toyama 3: 18. 1998 三 Parmelia hypomiltoides Vainio, Acta Societatis pro Fauna et Flora Fennica 7: 35. 1890. Type: BRAZIL. Minas GERAIS: Sítio (nowadays Antônio Carlos), Vainio, Lichenes Braziliensis exsiccati s.n. (holotype TUR-V2543), fide Fleig (1997).

Figures 16-17

Thallus pale gray, lobate, membranaceous, loosely adnate, saxicolous, 7.5-11.0 cm broad. Lobes irregularly branched, laterally overlapping, 2-17 mm wide, median axis extended to subascendant, surface smooth to scrobiculate, becoming rugose and reticulate cracked in the old parts; apical zone rounded, subconcave, margin usually ascendant and involute, sometimes revolute, undulate, entire to crenate or incise-crenate (sublacinulate); lateral marginal zone undulate and usually involute over the median axis and turning the lobes convex and almost canaliculate, margin crenate to sublacinulate. Lacinules, pustules and true isidia absent; maculae weak to distinct, punctiform, laminal. Cilia black, simple or rarely irregularly branched, $0.50-2.00$ $\times 0.02-0.05 \mathrm{~mm}$, from few to frequent, evenly distributed. Soralia concolor to the thallus, capitate or irregular, usually marginal and in the sublacinules apices, sometimes laminal, often forming arbuscular structures with sorediate apices (like a cauliflower); soredia granular or sometimes isidioid. Medulla white with orange areas $\mathrm{K}+$ red close to the soralia or in the older parts. Lower surface black, lustrous, smooth to slightly rugose or with veins, sometimes papillate; marginal zone brown to dark brown, often white or beige variegated, or completely black, opaque to lustrous, 2-6 $\mathrm{mm}$ wide, nude, with a sharp or attenuate limit, smooth to slightly rugose. Rhizines black, simple to irregularly branched, 0.20-3.00 × 0.02-0.05 mm, frequent, dispersed in groups. Apothecia absent [according to Fleig (1997), submarginal, imperforate, urceolate to patent and splitted when old, substipitate, with a wide base, rugose, amphithecium rugose, sorediate; ascospores 18.0-23.0 × 9.0-12.5 $\mu \mathrm{m}$, episporium 1.5-2.5 $\mu \mathrm{m}$ ]. Pycnidia absent [according to Fleig (1997), submarginal, sterile]; conidia unknown.

Color tests: cortex $\mathrm{K}+$ yellow, $\mathrm{UV}-$; medulla $\mathrm{K}-, \mathrm{C}-$, $\mathrm{KC}+$ rose $\rightarrow$ quickly orange, $\mathrm{P}-, \mathrm{UV}+$ greenish blue.

TLC: atranorin, alectoronic acid, $\alpha$-collatolic acid, skyrin and unidentified anthraquinone of Rf 49 in solvent $\mathrm{C}$.

Distribution: Oceania (Louwhoff \& Elix 1999) and South America (Hale 1965). In South America it is known to Brazil (Zahlbruckner 1930, Marcelli 2004) and Venezuela (Feuerer 2005). In Brazil it was recorded to MG (Hale 1965), PE (Kurokawa \& Moon 1998), RS (Spielmann 2006), SC (Fleig 1997) and SP (Hale 1965, Ribeiro 1998).

Specimens examined: BRAZIL. Rio Grande DO Sul: Boqueirão do Leão, Cascata do Gamelão, 
$29^{\circ} 18^{\prime} 13.7^{\prime \prime} \mathrm{S}, 52^{\circ} 26^{\prime} 51.7^{\prime \prime} \mathrm{W}, 500 \mathrm{~m}$ alt., on the steep slope near the waterfalls, shaded place (inside the forest), 1-II-2004,A.A. Spielmann \& M.A. Sulzbacher 1164 (SP), A.A. Spielmann \& M.A. Sulzbacher 1216 (SP), A.A. Spielmann \& M.A. Sulzbacher 1261 (SP), A.A. Spielmann \& M.A. Sulzbacher 1262 (SP).

Parmotrema hypomiltoides is distinguished by the production of soredia, often formed in arbuscular structures (like a cauliflower), the presence of alectoronic and $\alpha$-collatolic acid (medulla $\mathrm{KC}+$ rose $\rightarrow$ quickly orange, UV+ greenish blue) and the orange pigment $\mathrm{K}+$ red (unidentified anthraquinone) close to the soralia and lobe apices. In P. rampoddense (Nyl.) Hale the soralia are usually marginal and linear, and the orange pigment $\mathrm{K}+$ red (skyrin) is present only close to the lower cortex, in the old parts. Finally, $P$. mellissii (C.W. Dodge) Hale develops true isidia.

Fleig (1997) first proposed the new combination of Parmelia hypomiltoides in Parmotrema. At that time, the status of nomenclatural propositions in theses were still somewhat obscure in the St. Louis Code (Greuter et al.2003). Nevertheless, according to the Vienna Code (McNeill et al. 2007), Fleig's thesis is not effectively published. So the following author to propose the new combination, Kurokawa (1998, March) must be credited. Interesting to note that DePriest \& Hale (1998, April-June) also proposed this new combination, since Hale already recognized this good species although not validly published. Later (Hale \& DePriest 1999) they correctly used Kurokawa's combination.

Parmotrema indicum Hale, Mycotaxon 5(2): 436. 1977. Type: INDIA. Tamil NAdu: Kodaikanal, forest below Silver Cascade, on rocks in stream, elevation 1,800 m, M.E. Hale \& P.G. Patwardhan 43874 (holotype US), fide Hale (1977).

Figures 18, 39

Thallus greenish gray or mineral gray, lobate, loosely adnate, subcoriaceous, saxicolous, 20-28 $\mathrm{cm}$ broad. Lobes irregularly branched, laterally overlapping, 4-20 (-25) mm wide, surface smooth, opaque to lustrous, becoming rugose and cracked or reticulate cracked in the center; apical zone plane to subconcave, margin plane to undulate, often ascendant, entire to crenate; lateral marginal zone undulate to strongly undulate, subascendant to ascendant, involute in the older parts, sometimes revolute, margin entire to crenate. Lacinules, maculae, pustules and isidia absent. Cilia simple to branched,
0.50-3.50 (-4.50) × 0.05-0.15 $\mathrm{mm}$, frequent to abundant, evenly distributed. Soralia marginal, rarely submarginal, linear-continuous or interrupted, slightly wider when dense, sometimes orbicular and laminal in the old parts; soredia granular, sometimes dense and coalescing, sometimes darkened in the central areas. Medulla white, in some points with orange patches $\mathrm{K}+$ wine red near the lower cortex. Lower surface black, opaque or lustrous, papillate, smooth or rugose; marginal zone brown, sometimes ochraceous (especially in the older, sorediate parts), black or brown and black variegated, nude, lustrous, with an attenuate or sharp limit, smooth, papillate or rugose, (2-) 4-9 mm wide. Rhizines black, simple, $0.20-2.00(-4.00) \times 0.05-0.15 \mathrm{~mm}$, frequent to abundant, dispersed in groups. Apothecia unknown. Pycnidia submarginal, ostiole black; conidia filiform, straight or arcuate, $8.0-12.5 \times$ ca. $1.0 \mu \mathrm{m}$.

Color tests: cortex $\mathrm{K}+$ yellow, $\mathrm{UV}-$; medulla $\mathrm{K}-, \mathrm{C}+$ rose, $\mathrm{KC}+$ rose, $\mathrm{P}-, \mathrm{UV}-$.

TLC: atranorin, gyrophoric acid.

Distribution: Africa (Krog \& Swinscow 1981, as Parmelia indoafra; Swinscow \& Krog 1988), Asia (Hale 1977), and South America, where it is known to Brazil (Marcelli 2004); in Brazil it was recorded to RS (Spielmann 2006).

Specimens examined: BRAZIL. Rio GRANDE do SuL: Boqueirão do Leão, Linha Sinimbuzinho, Perau da Nega, 29²0'02.2”S, 52²6’27.9”W, 440 m alt., left margin of a stream, shaded by a shrub and grasses, 23-II-2004, A.A. Spielmann \& L.S. Canêz. 931 (SP); Sinimbu, Cava Funda, 2927'41.8'S, 52³1'11.7'W, $500 \mathrm{~m}$ alt., open place, 12-II-2003, A.A. Spielmann 61 (SP).

Parmotrema indicum is characterized by the robust thallus with ciliate lobes, marginal, linear soralia, the presence of gyrophoric acid (medulla $\mathrm{C}+$ rose, $\mathrm{KC}+$ rose) and filiform conidia, 8.0-12.5 $\times$ ca. 1.0 um. P. sancti-angeli (Lynge) Hale has sublageniform conidia, 5.0-7.5 $\times$ ca. $1.0 \mu \mathrm{m} . P$. permutatum (Stirton) Hale presents a yellow lower medulla (secalonic acid A) and $P$. rampoddense produces alectoronic acid (medulla UV+ greenish blue).

However, usually the thalli are not pycnidiate, and so the conidia type is useless in the distinction of $P$. indicum and $P$. sancti-angeli. During the present 
study, we realized other accessory differences between these species. $P$. indicum often has furcated or more branched cilia, also slightly thickened $(0.05-0.15$ $\mathrm{mm}$ wide), reminding the cilia from Canomaculina (figure 39), wide marginal soralia, together with orbicular and laminal ones in the older lobes, and a robust, usually coriaceous and adnate thallus. In $P$. sancti-angeli, the cilia are usually simple (rarely furcated) and thinner $(0.05-0.10 \mathrm{~mm})$. the marginal soralia are narrow and the orbicular, laminar ones absent. The thallus is usually membranaceous, with ascendant lobes

There is also the option to verify if the medulla of one specimen has norlobaridone, present only in P. indicum (Hale 1977, Krog \& Swinscow 1981, Swinscow \& Krog 1998). Yet this substance was not found in our specimens.

Although Fleig (1997) stated that P. indicum occurs in North America, we were unable to confirm this.

Parmotrema internexum (Nyl.) Hale ex DePriest \& B. Hale, Mycotaxon 67: 204. 1998 三 Parmelia internexa Nyl., Flora 68(24): 609. 1885. Type: BRAZIL. São PaUlo: Serra near to Santos, 1844, Weddel s.n. (holotype H-NYL35210), fide Fleig (1997).

\section{Figure 19}

Thallus greenish gray, lobate, adnate, membranaceous, saxicolous, 7-10 cm broad. Lobes irregularly branched, laterally overlapping, 2.5-7.0 $\mathrm{mm}$ wide, surface smooth to lightly scrobiculate, opaque to lustrous, becoming rugose and cracked in the center; apical zone plane to lightly concave or convex, plane to undulate; margin crenate or sometimes dentate; lateral marginal zone plane and imbricate to ascendant and involute, usually curling in the axils, undulate, margin entire to crenate. Lacinules, pustules and soralia absent. and maculae absent (but sometimes with irregular white patches). Cilia black, simple, few or rare, evenly distributed yet more abundant in the lobe axils, narrow, $0.20-0.80 \times$ $0.02-0.10 \mathrm{~mm}$. Isidia concolor to the thallus or with black or brown apices, cylindrical, simple, granular, branched or coralloid, erect, firm, more dense in the ascendant areas, eciliate, laminal to marginal, $0.05-0.40 \times 0.05-0.20 \mathrm{~mm}$. Medulla white. Lower surface black, lustrous, rugose; marginal zone brown or sometimes white variegated, nude or with young rhizines, lustrous, with an attenuate limit, smooth to subrugose or sometimes with veins, $0.7-3.5 \mathrm{~mm}$ wide. Rhizines black, simple or branched, dense and abundant, widely dispersed, $0.10-1.00 \times 0.02-0.05$ $\mathrm{mm}$. Apothecia absent [according to Fleig (1997), laminal, imperforate, 3-4 $\mathrm{mm}$ in diameter, urceolate, substipitate, entire or splitted, amphithecium isidiate, eciliate; ascospores 19.0-31.0 × 9.5-15.0 $\mu \mathrm{m}$, episporium $3 \mu \mathrm{m}]$. Pycnidia rare, submarginal, with black ostiole; conidia bacillar to slightly sublageniform, 5.0-7.0 × ca. $1.0 \mu \mathrm{m}$.

Color tests: cortex $\mathrm{K}+$ yellow, $\mathrm{UV}-$; medulla $\mathrm{K}+$ yellow, $\mathrm{C}-, \mathrm{KC}+$ rose-orange, $\mathrm{P}+$ slowly orange, $\mathrm{UV}-$.

TLC: atranorin, norlobaridone, stictic acid, constictic acid, cryptostictic acid and hypoconstictic acid.

Distribution: Africa (Dodge 1959, as Parmelia meiosperma), North America (Hale 1979, Esslinger 2008) and South America, where it is known to Brazil (Zahlbruckner 1930, Marcelli 2004). In Brazil it was recorded to MG (Ribeiro 1998), PR (Fleig 1997, Eliasaro 2001, Eliasaro \& Donha 2003), RS (Spielmann 2006), SC (Fleig 1997) and SP (Marcelli 1991, 1992, Fleig 1997).

Specimens examined: BRAZIL. Rio Grande Do SUL: Boqueirão do Leão, Linha Sinimbuzinho, Perau da Nega, 29²0'02.2"S, 52²6'27.9"W, $440 \mathrm{~m}$ alt., close to a stream, 24-II-2004, A.A. Spielmann \& L.S. Canêz 1252 (SP); Sinimbu, Cava Funda, 29 27'1.6"S, $52^{\circ} 31^{\prime} 02.9^{\prime \prime} \mathrm{W}, 520 \mathrm{~m}$ alt., open place, 5-I-2004, A.A. Spielmann \& L.S. Canêz, 1167 (SP).

Parmotrema internexum is characterized by the laminal isidia, ciliate lobes and the presence of norlobaridone (medulla $\mathrm{KC}+$ rose-orange) and stictic acid (medulla $\mathrm{K}+$ yellow, $\mathrm{P}+$ slowly orange). Parmotrema crinitum (Ach.) M. Choisy, has a robust thallus $(8-25 \mathrm{~cm}$ broad), wider lobes $(6-12 \mathrm{~mm})$, often ciliate isidia, and norlobaridone lacking (Hale 1965).

In solvent $\mathrm{C}$, the norlobaridone was "masked" inside the dot of stictic acid, but in solvent A the two dots were sharply distinct. However, the presence of this substance seems not universal, since it was not detected by Eliasaro (2001) and, according to Fleig (1997) and Eliasaro \& Donha (2003), it was present only in some specimens.

The synonymy of this species is unclear. Hale (1974d) placed Parmelia internexa f. meiosperma Hue in Pseudoparmelia Lynge. Fleig (1997) listed 
Parmelia internexa var. meiosperma Hue, $P$. meiosperma (Hue) C.W. Dodge and P. catharinesis Müll. Arg. f. isidiosa Müll. Arg. as synonyms of Parmotrema internexum. However, in Hale \& DePriest (1999) the first two names are synonyms of Hypotrachyna bogotensis (Vainio) Hale and the last one of Parmotrema crinitum (Ach.) M. Choisy.

Parmotrema mantiqueirense Hale, Bibliotheca Lichenologica 38: 113. 1990. Type: BRAZIL. Minas Gerais: Serra da Mantiqueira, zwischen 1,880 $\mathrm{m}$ und der Gipfelregion des Pedra Redonda in 2,000 m, 3-VII-1979, K. Kalb s.n. (holotype Kalb herbarium, isotype US), fide Hale (1990).

Figure 20

Thallus pale gray, lobate, subcoriaceous, fragile, loosely adnate, saxicolous, ca. $20 \mathrm{~cm}$ broad. Lobes irregularly branched, laterally overlapping, 7.0-27.0 $\mathrm{mm}$ wide, surface smooth, lustrous, reticulate cracked and slightly rugose in the older parts, usually with several scars; apical zone subconcave, undulate, ascendant to involute, margin sublacinulate, margin crenate; lateral marginal zone undulate, plane to ascendant, subimbricate, margin entire to sublacinulate. Lacinules and maculae absent. Cilia black, usually simple, sometimes furcated, usually thickened and spiky, 0.50-3.50 $\times \quad 0.05-0.10 \mathrm{~mm}$, abundant, evenly distributed. Pustules, soredia and isidia absent. Medulla white. Lower surface black, lustrous, smooth, papillate, with scars or cracks; marginal zone dark brown or sometimes black, 2.0-9.0 mm wide, nude, lustrous, smooth or papillate, having a wide area with young rhizines, with a sharp limit. Rhizines black, simple or sometimes furcated, rarely squarrose, narrow to thickened, $0.30-3.00 \times 0.02-0.10 \mathrm{~mm}$, abundant, dispersed in groups. Apothecia absent [according to Eliasaro (2001), laminal, adnate, disc dark brown, imperforate, 2-5 mm in diameter; ascospores 13-18 $\times 6-10 \mu \mathrm{m}]$. Pycnidia submarginal to rarely marginal, ostiole black; conidia bacillar to filiform, 6.5-11.0 $\times$ ca. $1.0 \mu \mathrm{m}$.

Color tests: cortex $\mathrm{K}+$ yellow, UV-; medulla $\mathrm{K}+$ yellow $\rightarrow$ blood red, $\mathrm{C}+$ yellow, $\mathrm{KC}+$ orange, $\mathrm{P}+$ yellow $\rightarrow$ orange, UV-.

TLC: atranorin, salazinic and consalazinic acids.

Distribution: known only to South America, where it was reported to Brazil (Hale 1990, Marcelli 2004). In
Brazil it was recorded to MG (Hale 1990, Fleig 1997, Ribeiro 1998), PR (Fleig 1997, Eliasaro 2001) and RS (Spielmann 2006).

Specimens examined: BRAZIL. Rio Grande do Sul: Barros Cassal, Nascente do Rio Pardo, 28 57'38.7'S, $52^{\circ} 38^{\prime} 53.9^{\prime \prime} \mathrm{W}, 700 \mathrm{~m}$ alt., open place, close to a stream, 27-I-2004, A.A. Spielmann et al. 938 (SP).

Parmotrema mantiqueirense is distinguished by the wide lobes $(7-27 \mathrm{~mm})$, emaculate upper surface, the presence of salazinic acid (medulla $\mathrm{K}+$ yellow $\rightarrow$ blood red, $\mathrm{P}+$ yellow $\rightarrow$ orange) and the absence of vegetative propagules. P. eurysacum (Hue) Hale has subpalmate lacinules, often branched and longer cilia $(1.5-5.0 \mathrm{~mm})$ and perforate apothecia.

Although Fleig (1997) asserted that $P$. mantiqueirense occurs in North America, we were unable to confirm this information.

Parmotrema melanothrix (Mont.) Hale, Phytologia 28(4): 337.1974 三 Parmelia urceolata Eschw. var. melanothrix Mont., Ann. Sci. Nat., Bot. ser. 2(2): 372. 1834. Type: BRAZIL. Gaudichaud 89 bis (holotype P), fide Hale (1965).

Figure 21

Thallus olivaceous gray, lobate, subcoriaceous, loosely adnate, saxicolous, $7.5 \mathrm{~cm}$ broad. Lobes irregularly branched, laterally overlapping, (3.0-) $5.0-10.0 \mathrm{~mm}$ wide, median axis plane to subascendant, surface smooth, lustrous, becoming slightly rugose towards the center; apical zone plane to undulate, margin crenate; lateral marginal zone undulate, plane to ascendant, margin crenate. Lacinules, pustules, soredia and isidia absent. Maculae distinct, punctiform, laminal. Cilia black or cupreous (then $\mathrm{K}+$ purplish), simple or rarely furcated, $1.00-4.00 \times 0.05-0.10 \mathrm{~mm}$, abundant, evenly distributed. Medulla white. Lower surface black, lustrous, veined; marginal zone beige or white variegated, usually with brown patches, sometimes with purplish patches, 4.0-8.0 (-15.0) $\mathrm{mm}$, nude, lustrous, smooth to rugose, with a sharp limit. Rhizines black or brown, simple to irregularly branched, narrow to thickened, $0.10-0.30 \times 0.10-0.20 \mathrm{~mm}$, frequent, dispersed in groups, sometimes reaching the margin. Apothecia urceolate, laminal, 1.0-2.0 $\mathrm{mm}$ in diameter, stipitate, with a wide base, margin crenate, amphithecium strongly maculated, ciliate, disc concave, epruinose, imperforate or rarely perforate (one from seven apothecia seen), immature; 
hymenium little developed and ascospores absent [according to Hale (1965), hymenium 80-100 $\mu \mathrm{m}$; ascospores 20-26 × 10-16 $\mu \mathrm{m}$, episporium 2-3 $\mu \mathrm{m}]$. Pycnidia submarginal or touching the margin, conspicuous, without prominent margin, ostiole black; conidia bacillar to filiform, 6.5-10.0 × ca. 0.5 $\mu \mathrm{m}$.

Color tests: cortex $\mathrm{K}+$ yellow, $\mathrm{UV}-$; medulla $\mathrm{K}-, \mathrm{C}-$, $\mathrm{KC}-, \mathrm{P}-, \mathrm{UV}-$.

TLC: atranorin, protopraesorediosic acid.

Distribution: Oceania (Feuerer 2005), Africa (Réunion Island) and South America (Hale 1965). In South America it is known to Brazil (Marcelli 2004), Peru (Feuerer 2005) and Venezuela (Vareschi 1962). In Brazil it was recorded to MA (Hale 1965), MG (Lynge 1914, Hale 1965, Ribeiro 1998), MS (Osorio 1992b), MT (Lynge 1914, Fleig 1997, Ribeiro 1998), PR (Hale 1965, Fleig 1997, Eliasaro 2001), RJ (Hale 1965), RS (Spielmann 2006), SC (Fleig 1997) and SP (Hale 1965; Marcelli 1991, 1992, Ribeiro 1998).

Specimens examined: BRAZIL. Rio GRANDE do SUL: Boqueirão do Leão, Linha Sinimbuzinho, Perau da Nega, 2920'02.2”S, 52 ${ }^{\circ} 26^{\prime} 27.9^{\prime \prime} \mathrm{W}, 440 \mathrm{~m}$ alt., close to a stream, slightly shaded, 24-II-2004, A.A. Spielmann \& L.S. Canêz 1033 (SP).

Parmotrema melanothrix is distinguished by the long, abundant cilia (1-4 mm), maculate upper cortex, conidia bacillar to filiform, 6.5-10.0 $\mu \mathrm{m}$ long, just protopraesorediosic acid in the medulla (spot tests negative) and the absence of vegetative propagules. P. catarinae Hale has gyrophoric acid (Hale 1986). P. glaucocarpoides (Zahlbr.) Hale has sublageniform conidia 5-6 $\mu \mathrm{m}$ long and protolichesterinic acid (Krog \& Swinscow (1981).

According to Hale (1965), Fleig (1997), Ribeiro (1998) and Eliasaro (2001), the medullar substance typical of P. melanothrix is protolichesterinic acid, yet in the specimen here studied just protopraesorediosic acid was found.

Parmotrema mellissii (C.W. Dodge) Hale, Phytologia 28(4): 337. 1974 三 Parmelia mellissii C.W. Dodge, Annals of the Missouri Botanical Garden 46(1-2): 134. 1959. Type: AFRICA. Santa Helena, J.C. Melliss 23 (holotype K, isotype US), fide Hale (1965) and Fleig (1997).

Figures 22-23, 41
Thallus greenish gray, lobate, membranaceous to subcoriaceous, loosely adnate, saxicolous, 15 $\mathrm{cm}$ broad. Lobes irregularly branched, laterally overlapping, (3.0-)4.0-10.0 mm wide, surface smooth or cracked, opaque, becoming reticulate in the center; apical zone plane to subconcave, undulate, margin crenate; lateral marginal zone undulate, ascendant and involute or subimbricate, margin crenate. Lacinules, pustules and maculae absent. Cilia black, simple or irregularly branched, $0.50-3.00$ $\times \quad 0.02-0.05 \mathrm{~mm}$, abundant, evenly distributed. Soredia originated from isidia. Isidia concolor to the upper cortex, apices brown or black, usually simple or with two to four branches, cylindrical or granular, sometimes coarsely granular and coalescing, rarely coralloid, $0.10-0.30 \times 0.05-0.10 \mathrm{~mm}$, often raised from papillae, wrinkles or from the cortex fragmentation, submarginal, laminal or marginal, erect, firm or caducous, apex often ciliate, giving rise to soredia or not. Medulla white, except for some orange old areas $(\mathrm{K}+$ wine red). Lower surface black, opaque to lustrous, smooth to rugose; marginal zone brown or rarely black, sometimes white variegated, 2.0-5.0 mm wide, nude, lustrous or sometimes opaque, smooth to rugose, with a sharp or attenuate limit. Rhizines black, simple or irregularly branched, $1.00-3.50 \times 0.05-0.10 \mathrm{~mm}$, abundant, dispersed in groups. Apothecia and pycnidia unknown.

Color tests: cortex $\mathrm{K}+$ yellow, $\mathrm{UV}-$; medulla $\mathrm{K}-, \mathrm{C}-$, $\mathrm{KC}+$ rose $\rightarrow$ quickly orange, $\mathrm{P}-, \mathrm{UV}+$ greenish blue.

TLC: atranorin, alectoronic acid, $\alpha$-collatolic acid and skyrin.

Distribution: Oceania (Malcolm \& Galloway 1997, Louwhoff \& Elix 1998, 1999, Kantvilas et al. 2002), Asia (Hale 1965, Awasthi 1976, Kurokawa 1991b, 1993, Kurokawa \& Lai 2001, Louwhoff \& Elix 2002), Africa (Krog \& Swinscow 1981, Swinscow \& Krog 1988), North America (Hale 1965, Nash \& Elix 2002a), Central America (Hale 1965) and South America (Hale 1965). In South America it is known to Brazil (Marcelli 2004), Chile (Feuerer 2005), Colombia (Hale 1965), Guyana (Feuerer 2005) and Uruguay (Osorio 1992a). In Brazil it was recorded to MG (Hale 1965, Ribeiro 1998), PR (Eliasaro 2001), RS (Spielmann 2006), SC (Fleig 1997) and SP (Pereira \& Marcelli 1989, Ribeiro 1998).

Specimens examined: BRAZIL. Rio GRANDE do SuL: Sinimbu, Cava Funda, 2927'41.8'S, 52³1'11.7'W, 
$500 \mathrm{~m}$ alt., open place, 12-II-2003, A.A. Spielmann 111 (SP).

Parmotrema mellissii is characterized by the isidiate thallus with alectoronic acid (medulla $\mathrm{KC}+$ rose $\rightarrow$ quickly orange, UV+ greenish blue). The similar $P$. hypomiltoides do not form isidia, but soredia, often in arbuscular structures. The cilia are simple to irregularly branched (figure 41).

Parmotrema mordenii (Hale) Hale, Phytologia 28(4): 337.1974 三 Parmelia mordenii Hale, Smithsonian Contributions to Botany 4: 19. 1971. Type: DOMINICA. North of Coulibistri, ca. $30 \mathrm{~m}$ alt. M.E. Hale 35649 (holotype US, isotypes BM, UPS), fide Hale (1971b).

Figure 24

Thallus greenish gray or with some gray patches, especially in the lobe apices, lobate, membranaceous, adnate, saxicolous, $15 \mathrm{~cm}$ broad. Lobes irregularly branched, laterally overlapping, 2-10 mm wide, surface smooth or sometimes cracked, opaque to sublustrous, becoming rugose and cracked in the old parts; apical zone plane to subconcave, undulate, often involute, margin entire to crenate; lateral marginal zone undulate, imbricate to ascendant, especially in the axils, giving a coiled look to the lobe, sometimes ascendant with the apex involute. Lacinules, maculae, isidia, pustules and cilia absent. Soralia whitish, usually marginal and linear, or sometimes submarginal to laminal and with a pustular look, rarely capitate, turning the lateral margins ascendant and involute, or frequently sinuous; soredia subgranular. Medulla white. Lower surface black, lustrous, rugose; marginal zone brown, lustrous, 2.0-6.0 mm wide, nude, smooth, rugose or papillate, with attenuate limit. Rhizines concolor to the lower surface, simple although usually joined and forming disks of adherence to the substrate, $0.10-0.50 \times 0.05-0.10 \mathrm{~mm}$, frequent, dispersed in small groups. Apothecia unknown. Pycnidia laminal to submarginal, barely conspicuous, ostiole black; conidia sublageniform, 4.0-6.5 × $1.0 \mu \mathrm{m}$.

Color tests: cortex $\mathrm{K}+$ yellow, UV-; medulla $\mathrm{K}+$ yellow, $\mathrm{C}-, \mathrm{KC}-, \mathrm{P}+$ slowly weak yellow, $\mathrm{UV}-$.

TLC: atranorin (cortical and medullar), caperatic acid, protopraesorediosic acid and protolichesterinic acid.

Distribution: Africa (Winnem 1975), Central America (Hale 1971b), North America (Jackson \& Hopkins
1980, Esslinger 2008) and South America (Feuerer 2005). In South America it is known to Brazil (Marcelli 1991) and Venezuela (Feuerer 2005). In Brazil it was recorded to SP (Marcelli 1991).

Specimens examined: BRAZIL. Rio Grande do SuL: Sinimbu, Cava Funda, 2927'41.8'S, 52³1'11.7'W, $500 \mathrm{~m}$ alt., open place, 12-II-2003, A.A. Spielmann 110 (SP).

Parmotrema mordenii is recognizable by the adnate thallus, eciliate lobes, presence of soralia and medulla with atranorin $(\mathrm{K}+$ yellow, $\mathrm{P}+$ slowly weak yellow). In P. praesorediosum the soralia are usually crescent-shaped and atranorin is lacking in the medulla. Although Sipman (2005) also treat these two species as distinct, Krog \& Swinscow (1981) putted $P$. mordenii as synonym of $P$. praesorediosum.

In the protologue of P. mordenii, Hale (1971b) stated that the soralia could occasionally form coralloid subfatiscent structures. We found in the specimen collected some pustular, capitate soralia that remember this description, however, more material is necessary to prove if this is also a good feature to take this species apart from P. praesorediosum.

Parmotrema perlatum (Huds.) M. Choisy, Catalogue des lichens de la region lyonnaise, fasc. 9, Bulletin mensuel de la Société Linnéenne de Lyon et des Société Botanique de Lyon 21: 174. 1952 三 Parmelia perlata (Huds.) Ach., Methodus qua omnes detectos lichenes: 216. 1803. Type: in Dillenius Herbarium (OXF), illustrated in the plate 20, figure 39B in Dillenius, Historia Muscorum. p. 197, 1742, fide Fleig (1997).

= Parmotrema chinense (Osbeck) Hale \& Ahti, Taxon 35: 133. 1986.

Figure 26

Thallus greenish gray or brownish in herbarium, lobate, membranaceous, loosely adnate, saxicolous, $7.0 \mathrm{~cm}$ broad. Lobes irregularly branched, laterally overlapping, 4.0-7.0 mm wide, surface continuous, smooth to subrugose, opaque to sublustrous, becoming reticulate cracked in the center; apical zone subconcave, undulate to plane, margin crenate; lateral marginal zone undulate, imbricate to ascendant and involute, margin crenate to incise-crenate (sublacinulate). Lacinules, maculae, pustules and isidia absent. Cilia black, simple, (0.20-) 0.50-1.00 $\times 0.02(-0.10) \mathrm{mm}$, frequent, evenly distributed but 
less common in the lobe apices. Soralia concolor to the thallus, linear, marginal, sometimes wide or subcontinuous, turning the margins undulate and involute, or orbicular to capitate in the sublacinules; soredia farinose to subgranular. Medulla white. Lower surface black, lustrous, rugose; marginal zone brown, $1.0-2.0 \mathrm{~mm}$, lustrous, smooth to rugose, with a sharp limit. Rhizines black, simple, $0.30-1.00$ $\times$ 0.01-0.02 mm, abundant, evenly distributed. Apothecia absent [according to Hale (1965), 3-5 mm in diameter, disc imperforate; hymenium 70-80 $\mu \mathrm{m}$; ascospores $22-30 \times 13-16 \mu \mathrm{m}$, episporium $3 \mu \mathrm{m}$ ]. Pycnidia absent [according to Maas-Gesteranus (1947, as Parmelia trichotera Hue), pycnidia with a black ostiole; conidia cylindrical, 5-7 × ca. $1 \mu \mathrm{m}]$.

Color tests: cortex $\mathrm{K}+$ yellow, $\mathrm{UV}-$; medulla $\mathrm{K}+$ yellow, $\mathrm{C}-, \mathrm{KC}-, \mathrm{P}+$ orange, $\mathrm{UV}-$.

TLC: atranorin, stictic acid, constictic acid, cryptostictic acid, hypoconstictic acid, hypostictic acid, menegazziaic acid and norstictic acid.

Distribution: Oceania (Elix 1994, Malcolm \& Galloway 1997, Louwhoff \& Elix 1999, Kantvilas et al. 2002), Asia (Hale 1965, Kurokawa 1991b, Kurokawa \& Lai 2001), Europe (Hale 1965), Africa (Hale 1965, Swinscow \& Krog 1988), North America (Hale 1965, Brodo et al. 2001, Nash \& Elix 2002a), Central America (Hale 1965), and South America (Hale 1965). In South America it is known to Argentina (Adler 1992, Calvelo \& Liberatore 2002), Bolivia (Feuerer 2005), Brazil (Marcelli 2004), Chile (Hale 1965), Uruguay (Osorio 1972) and Venezuela (Feuerer 2005). In Brazil it was recorded to MG (Ribeiro 1998), PR (Eliasaro 2001, Eliasaro \& Donha 2003), RS (Spielmann 2006), SC (Fleig 1997) and SP (Marcelli 1991).

Specimens examined: BRAZIL. Rio Grande do SuL: Sinimbu, Cava Funda, 29²7'41.8'S, 52³1'11.7’'W, 500 m alt., open place, 4-II-2003, A.A. Spielmann 65 (SP).

Parmotrema perlatum is distinguished by the ciliate lobes, marginal soralia (capitate in the sublacinules) and the presence of stictic acid (medulla $\mathrm{K}+$ yellow, $\mathrm{P}+$ orange). Parmotrema bangii can be differentiated for the formation of sorediose pustules, while P. hypoleucinum (J. Steiner) Hale has small maculae and a wide white margin in the lower surface (Brodo et al. 2001). In P. hypotropum
(Nyl.) Hale there's also a lower white margin (as $P$. hypoleucinum) but it has just norstictic acid, the medulla being $\mathrm{K}+$ yellow $\rightarrow$ red (Brodo et al. 2001). Finally, $P$. rampoddense, although with a similar morphology, presents alectoronic acid (medulla $\mathrm{KC}+$ rose $\rightarrow$ quickly orange, UV+ greenish blue).

Some authors (Hale 1965, Swinscow \& Krog 1988, Eliasaro 2001, Sipman 2005) described $P$. perlatum with revolute lobes, while Fleig (1997) called them involute and Hale \& Cole (1988) as "revolute with the apex involute". This last observation agrees with the specimen here seen. The presence of trace of norstictic acid in the solvent C, already reported by Elix (1994) and Brodo et al . (2001), was confirmed here too.

Hale \& Ahti (1986) discovered an earlier name, Lichen chinensis that became universally accepted. Nevertheless recently Hawksworth (2004) reestablished Parmotrema perlatum as the valid name.

Parmotrema praesorediosum (Nyl.) Hale, Phytologia 28(4): 338.1974 = Parmelia praesorediosa Nyl., Sert. Lich. Trop. Labuan Singapore: 18. 1891. Type: SINGAPURA. 30-XI-1879, E. Almquist (holotype H-NYL35547, isotype S), fide Fleig (1997).

Figure 27

Thallus aluminium gray or slightly straw pinkish, lobate, adnate, membranaceous, saxicolous, $6.0-10.5 \mathrm{~cm}$ broad. Lobes irregularly branched, laterally overlapping, $3.0-10.0 \mathrm{~mm}$ wide, surface smooth, opaque to sublustrous, becoming rugose and cracked in the old parts; apical zone subplane to slightly concave, undulate, usually ascendant, margin entire to subcrenate; lateral marginal zone undulate, imbricate to ascendant, margin entire to crenate. Lacinules, maculae, pustules, isidia and cilia absent. Soralia whitish or slightly grayish, usually crescent-shaped or more wide and dense, or orbicular to capitate, marginal to submarginal or laminal, turning the lateral margins ascendant and sometimes densely sinuous; soredia subgranular. Medulla white. Lower surface black, lustrous or opaque, smooth to rugose; marginal zone pale brown or sometimes black or white variegated, 3.0-7.0 $\mathrm{mm}$ wide, lustrous or opaque, with a sharp limit, smooth to reticulate rugose or with veins, sometimes papillate. Rhizines black or concolor to the lower surface, sometimes brown with white apices, usually 
simple, $0.20-0.80 \times 0.05-0.10 \mathrm{~mm}$, few to frequent, dispersed in small groups. Apothecia laminal, very immature (asci and ascospores not developed), rare [according to Hale (1965), apothecia 4-10 $\mathrm{mm}$ in diameter, with a short stipe, amphithecium rugose and sorediate, disc imperforate; hymenium 70-80 $\mu \mathrm{m}$; ascospores $15-21 \times 7-10 \mu \mathrm{m}$, episporium 1.2$2.0 \mu \mathrm{m}]$. Pycnidia submarginal to laminal, ostiole black; conidia sublageniform, 4.0-7.5 × ca. $1.0 \mu \mathrm{m}$.

Color tests: cortex $\mathrm{K}+$ yellow, $\mathrm{UV}-$; medulla $\mathrm{K}-, \mathrm{C}-$, $\mathrm{KC}-, \mathrm{P}-, \mathrm{UV}-$.

TLC: atranorin, praesorediosic acid, caperatic acid, protolichesterinic acid and an unidentified substance of Rf 54 in solvent C.

Distribution: Oceania (Elix 1994, Louwhoff \& Elix 1999), Africa (Hale 1965, Swinscow \& Krog 1988), Asia (Hale 1965), North America (Hale 1965, Esslinger 2008), Central America (Hale 1965) and South America (Hale 1965). In South America it is known to Argentina (Hale 1965, Calvelo \& Liberatore 2002), Brazil (Hale 1965, Marcelli 2004), Chile (Feuerer 2005), French Guiana, Paraguay (Hale 1965), Uruguay (Osorio 1992a) and Venezuela (Hale 1965, Vareschi 1973). In Brazil it was recorded to BA(Lynge 1914, as Parmelia capitata), MG (Hale 1965), MS (Fleig \& Riquelme 1991), PA (Brako et al. 1985), RJ (Hale 1965), RS (Spielmann 2006), SC (Fleig 1997) and SP (Marcelli 1991, 1992).

Specimens examined: BRAZIL. Rio GRANDE Do SUL: Santa Cruz do Sul, margin from highway RST-287, km 102,2941'03.3'"S, 52²5'33.6”'W, 150 m alt., 28VII-2003, A.A. Spielmann 386 (SP), A.A. Spielmann 399 (SP).

Parmotrema praesorediosum is characterized by the adnate thallus, eciliate lobos, crescentshaped soralia and medulla with caperatic acid, praesorediosic acid and protolichesterinic acid (spot tests negative). In P. mordenii the soralia are usually marginal and linear, sometimes pustular and laminal, and atranorin is present in the medulla ( $\mathrm{K}+$ yellow). $P$. dilatatum (Vainio) Hale has a different chemistry, with trace of usnic acid in the cortex and medulla with protocetraric acid and echinocarpic acid (Fleig 1997).

The caperatic acid was reported by Hale (1965) and Awasthi (1976), but several authors don't found it, like Elix (1994), Fleig (1997), Kurokawa \& Lai
(2001), Louwhoff \& Elix (1999) and Nash \& Elix (2002a). Maybe it's necessary to revise the chemical identification of this lichen.

Parmotrema rampoddense (Nyl.) Hale, Phytologia 28(4): 338.1974 = Parmelia rampoddensis Nylander, Acta Societatis Scietiarum Fennicae 26(10): 7. 1900. Type: SRI LANKA. Ramboda, Almquist (holotype H-NYL35555, isotype S), fide Hale (1965).

Figure 28

Thallus greenish gray ti pale gray, lobate, membranaceous to subcoriaceous, loosely adnate, corticicolous or saxicolous, $4.5-20.0 \mathrm{~cm}$ broad. Lobes irregularly branched, laterally overlapping to crowded, 4.0-20.0 mm wide, surface smooth, rugose, irregular or scrobiculate, opaque to lustrous, becoming rugose and cracked towards the center; apical zone plane to concave, usually ascendant and sometimes revolute, undulate, margin entire to subcrenate or sublacinulate; lateral marginal zone undulate, plane, ascendant, subimbricate or involute, margin entire to subcrenate or sublacinulate to lacinulate. Lacinules simple, plane, 0.5-2.5 (-4.0) $\times 0.5-2.5 \mathrm{~mm}$, evenly distributed or sometimes only in the center, apex truncate to rounded, lower surface black, rarely brown or white variegated; maculae absent. Cilia black or cupreous and then $\mathrm{K}+$ purplish, simple, furcated or irregularly branched, $0.50-6.0 \times 0.02-0.10 \mathrm{~mm}$, frequent to abundant, evenly distributed. Pustules and isidia absent. Soralia whitish, marginal to submarginal, linear interrupted or wider (up to $2.5 \mathrm{~mm}$ ) and approaching the lamina, turning the lateral margins involute, or capitate, laminal or in the lacinules apices; soredia farinose to grossly granular, coalescing in the older parts, sometimes developing small cilia. Medulla white, except by some orange parts $\mathrm{K}+$ red in older parts, close to the lower cortex. Lower surface black, lustrous, smooth to rugose; marginal zone brown or sometimes black or with parts white or beige variegated close to the soralia, 1.0-4.0 $\mathrm{mm}$ wide, nude, sublustrous, lustrous or opaque, smooth to rugose or rugose-reticulate, rarely with veins, with an attenuate or sharp limit. Rhizines black, simple, furcated or irregularly branched, $0.20-3.50 \times 0.02-0.05(-0.10) \mathrm{mm}$, usually longer in the marginal zone than in the central lobe margins, frequent to abundant, dispersed in groups by almost all surface, sometimes some rhizines reaching the 
margin. Apothecia absent [according to Hale (1965), 3-10 $\mathrm{mm}$ in diameter, amphithecium sorediate, disc imperforate; hymenium 65-75 $\mu \mathrm{m}$; ascospores 10-12 $\times 6-7 \mu \mathrm{m}$, episporium $1 \mu \mathrm{m}]$. Pycnidia submarginal to laminal, barely conspicuous, without prominent margin, ostiole black or brown; conidia bacillar to filiform, 5.0-9.0 × ca. $1.0 \mu \mathrm{m}$.

Color tests: cortex $\mathrm{K}+$ yellow, UV-; medulla $\mathrm{K}-, \mathrm{C}+$ rose $\rightarrow$ quickly orange or $\mathrm{C}-$ (rarely $\mathrm{C}+$ yellowish in some areas), $\mathrm{KC}+$ rose $\rightarrow$ quickly orange, $\mathrm{P}-$, $\mathrm{UV}+$ greenish blue. Soredia sometimes UV+ slightly yellowish . The orange pigment (skyrin) is lacking in some specimens.

TLC: atranorin, alectoronic acid, $\alpha$-collatolic acid and skyrin.

Distribution: Oceania (Hale 1965, Elix 1994, Louwhoff \& Elix 1999); Asia (Hale 1965, Awasthi 1976, Kurokawa 1991b, Kurokawa \& Lai 2001, Elix \& Schumm 2001, Louwhoff \& Elix 2002), Africa (Hale 1965, Winnem 1975), North America (Hale 1965, Brodo et al. 2001, Esslinger 2008), Central America (Hale 1965) and South America (Hale 1965). In South America it is known to Argentina (Calvelo \& Liberatore 2002), Bolivia (Hale 1965), Brazil (Marcelli 2004), Chile (Feuerer 2005), Colombia (Hale 1965), Guyana (Feuerer 2005), Uruguay (Osorio 1992a) and Venezuela (Feuerer 2005). In Brazil it was recorded to MG (Hale 1965), PR (Eliasaro 2001, 2006), RS (Spielmann 2006) and SP (Ribeiro 1998).

Specimens examined: BRAZIL. Rio Grande do Sul: Boqueirão do Leão, Linha Sinimbuzinho, Perau da Nega, 2920'02.2'S, 52²6'27.9”'W, 440 m alt., slightly shaded place, 24-II-2004, A.A. Spielmann \& L.S. Canêz 1254 (SP); Herveiras, $29^{\circ} 25^{\prime} 53.7^{\prime}$ 'S, $52^{\circ} 40^{\prime} 19.6^{\prime \prime} \mathrm{W}, 570 \mathrm{~m}$ alt., open place, 20-I-2004, A.A. Spielmann \& J. Putzke 1253 (SP); Sinimbu, Cava Funda, 29²7'41.8'S, 52³1'11.7'W, $500 \mathrm{~m}$ alt., open place, 4-II-2003, A.A. Spielmann 09 (SP), A.A. Spielmann 17 (SP), A.A. Spielmann 25 (SP); idem, 12-II-2003 A.A. Spielmann 94 (SP); idem, open place, 12-II-2003, A.A. Spielmann 106 (SP); idem, Linha Almeida, 29²3'20.2”'S, 52³0'21.9”'W, wrapping a wooden stub, close to ground, open place, 4-VII2003, A.A. Spielmann 255 (SP); idem, Linha Almeida, 29²3'20.2”'S, 52 30'21.9"W, on bark of Araucaria angustifolia, open place, 5-I-2004, A.A. Spielmann \& L.S. Canêz 1204 (SP); idem, Salto Rio Pardinho, $29^{\circ} 22^{\prime} 54.8^{\prime \prime} \mathrm{S}, 52^{\circ} 32^{\prime} 33.2^{\prime \prime} \mathrm{W}, 250 \mathrm{~m}$ alt., at river's margin, shaded place, 2-II-2003, A.A. Spielmann \& M.A. Sulzbacher 471 (SP).

Parmotrema rampoddense is recognizable by the ciliate lobes, marginal to submarginal soralia, the presence of alectoronic acid (medulla UV+ greenish blue), conidia bacillar to filiform, 5.0-9.0 $\times$ ca. 1.0 $\mu \mathrm{m}$ and the orange pigment $\mathrm{K}+$ red (skyrin). In $P$. pooli (C.W. Dodge) Krog \& Swinscow the conidia are sublageniform, 7-8 $\mu$ m long (Krog \& Swinscow 1981). Parmotrema hypomiltoides develops soredia in arbuscular structures, while P. mellissii has ciliate isidia and finally in $P$. exquisitum (Kurok.) DePriest \& Hale, reported for Uruguay, the lobes are eciliate (Kurokawa 1987). Nevertheless, Fleig (1997) regarded this last species as synonym of $P$. rampoddense, stating that the type of $P$. exquisitum seems an old specimen that suffered weather conditions.

The $\mathrm{K}+$ purplish reaction of some cilia was also observed in the type of P. rampoddense (Krog \& Swinscow 1981).

Parmotrema sancti-angeli (Lynge) Hale, Phytologia 28(4): 339. 1974 三 Parmelia sancti-angeli Lynge, Arkiv för botanik 13(13): 35. 1914. Type: BRAZIL. Rio Grande do Sul: Colonia Santo Angelo prope Cachoeira (nowadays Agudo), Malme s.n. (holotype S, isotype US), fide Hale (1965) and Fleig (1997).

Figure 30

Thallus greenish gray, lobate, membranaceous to subcoriaceous, loosely adnate, corticicolous or saxicolous, $8.5-11.0 \mathrm{~cm}$ broad. Lobes irregularly branched, laterally overlapping, contiguous or crowded, 4.0-20.0(-25.0) $\mathrm{mm}$ wide, surface smooth or slightly rugose, opaque to sublustrous, becoming rugose and cracked in the center; apical zone plane to subconcave, undulate, margin crenate; lateral marginal zone undulate or strongly undulate towards the center, ascendant, sometimes involute, margin entire to crenate or sublacinulate. Lacinules, pustules, isidia and maculae absent. Cilia simple or less frequently furcated, $(0.50-) 1.00-5.50 \times 0.05-$ $0.10 \mathrm{~mm}$, usually ascendant, frequent to abundant, evenly distributed. Soralia white, linear, continuous or interrupted, wider in the thallus center, marginal; soredia farinose to subgranular. Medulla white. Lower surface black, lustrous, smooth to rugose; marginal zone pale brown, sometimes dark brown, white variegated or cream color, or still black, 3-15 
$\mathrm{mm}$ wide, nude, lustrous, smooth to papillate or rugose, sometimes strongly veined, with a sharp or attenuate limit. Rhizines black, cream color, pale brown, whitish or brown with the apices whitish, or concolor to the margin, usually simple, sometimes furcated or rarely more branched, $0.50-2.50 \times$ (0.02-) 0.05-0.15 (-0.20) mm, frequent to abundant, dispersed in groups. Apothecia absent [according to Hale (1965), adnate, disc imperforate; hymenium 65 $\mu \mathrm{m}$; ascospores 13-18 × 7-10 $\mu \mathrm{m}$, episporium 1.0 $\mu \mathrm{m}$, but see the Notes below]. Pycnidia submarginal, ostiole black; conidia sublageniform, 5.0-9.0 × ca. $1.0 \mu \mathrm{m}$.

Color tests: cortex $\mathrm{K}+$ yellow, $\mathrm{UV}-$; medulla $\mathrm{K}-, \mathrm{C}+$ rose or red, $\mathrm{KC}+$ rose or red, $\mathrm{P}-, \mathrm{UV}-$.

TLC: atranorin, gyrophoric acid.

Distribution: Oceania (Elix 1994, Louwhoff \& Elix 1999), Asia (Hale 1965, Awasthi 1976, Kurokawa 1993, Kurokawa \& Lai 2001, Elix \& Schumm 2001), Africa (Hale 1965, Winnen 1975, Krog \& Swinscow 1981, Swinscow \& Krog 1988) and Americas (Hale 1965). In South America it is known to Argentina (Hale 1965, Calvelo \& Liberatore 2002), Brazil (Zahlbruckner 1930, Marcelli 2004), Chile, Colombia (Hale 1965) and Venezuela (Hale 1965, Vareschi 1973). In Brazil, it was recorded to MG (Hale 1965, Ribeiro 1998), PR (Osorio 1977a,b, Fleig 1997, Eliasaro 2001), RS (Spielmann 2006), SC (Fleig 1997) and SP (Hale 1965, Osorio 1989, Pereira \& Marcelli 1989, Marcelli 1991, Ribeiro 1998).

Specimens examined: BRAZIL. Rio GRANDE Do SuL: Boqueirão do Leão, Linha Sinimbuzinho, Perau da

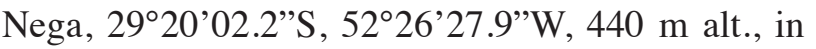
the stream's margin and close to the street, in a little shaded place, 24-II-2004, A.A. Spielmann \& L.S.Canêz 1061 (SP); idem, Cascata do Gamelão, 29¹8'13.7'’S, $52^{\circ} 26^{\prime} 51.7^{\prime \prime} \mathrm{W}, 500 \mathrm{~m}$ alt., in the stream's margin, slightly shaded, 31-I-2004, A.A. Spielmann \& M.A. Sulzbacher 1110 (SP); Herveiras, 29²5'53.7'S, $52^{\circ} 40$ '19.6”'W, $570 \mathrm{~m}$ alt., slightly shaded, 24-I-2004, A.A. Spielmann et al. 727 (SP); Sobradinho, margin from RST-481, next to the crossroads, $29^{\circ} 24^{\prime} 20.2$ "S, $53^{\circ} 01^{\prime} 25.9^{\prime}$ 'W, $375 \mathrm{~m}$ alt., open place, 17-VII-2003, A.A. Spielmann 332 (SP).

Parmotrema sancti-angeli is distinguished by the ciliate lobes, marginal and linear soralia, the presence of gyrophoric acid (medulla $\mathrm{C}+$ rose or red) and sublageniform conidia 5.0-9.0 × ca. $1.0 \mu \mathrm{m}$. In $P$. indicum the thallus is robust and the conidia filiform, 8.0-12.5 × ca. $1.0 \mu \mathrm{m}$ (see also the Notes under this species), and P. permutatum (Stirton) Hale has the lower medulla yellow, because the presence of secalonic acid A (Fleig 1997).

Parmotrema spinibarbe (Kurok.) Hale ex DePriest \& B. Hale, Mycotaxon 67: 204. 1998 = Parmelia spinibarbis Kurok., Bulletin of the National Science Museum Tokyo 17(4): 299. 1974. Type: BRAZIL. Rio de JANEIRo: Petrópolis, ca. $810 \mathrm{~m}$ alt., Kurokawa 8348 (holotype TNS, isotypes G, O, US, W), fide Kurokawa (1974) and Fleig (1997).

Figure 32

Thallus aluminium gray, lobate, membranaceous, loosely adnate, saxicolous, $16.5 \mathrm{~cm}$ broad. Lobes irregularly branched, laterally overlapping, 4.0-11.0 $\mathrm{mm}$ wide, surface smooth, lustrous or opaque, becoming reticulate cracked in the center; apical zone plane to subconcave, usually ascendant, sometimes involute, undulate, margin strongly crenate; lateral marginal zone undulate, plane to ascendant, usually involute, margin crenate to incise-crenate (sublacinulate). Lacinules and isidia absent. Maculae weak, punctiform, laminal. Cilia black, simple or furcated, usually spiky, $0.20-2.00 \times 0.02-0.15$ $\mathrm{mm}$, frequent, dense to spread, evenly distributed. Pustules capitate, marginal to submarginal, fragmenting in soredia. Soralia pustular, marginal to submarginal, at first narrow, then becoming wider and turning the margins thickened and involute, or subcapitate; soredia granular, sometimes isidioid, usually coalescing and somewhat stiff, forming a granular aggregate. Medulla white, sometimes with orange patches $\mathrm{K}+$ yellow $\rightarrow$ blood red close to the lower cortex. Lower surface black, lustrous, smooth to rugose; marginal zone brown dark, $1.5-4.0 \mathrm{~mm}$ wide, nude, lustrous, smooth to rugose, with attenuate to sharp limit. Rhizines black, simple or irregularly branched, $0.20-2.00 \times 0.02-0.15 \mathrm{~mm}$, abundant, covering almost all the surface. Apothecia absent [according to Kurokawa (1974), stipitate, 3-10 mm in diameter, disc dark brown, perforate, splitted when mature; hymenium ca. $50 \mu \mathrm{m}$; ascospores $12-14 \times$ 7-10 $\mu \mathrm{m}]$. Pycnidia submarginal, without prominent margin, ostiole black; conidia filiform, straight or slightly arcuate, $7.5-12.0 \times \mathrm{ca} .1 .0 \mu \mathrm{m}$.

Color tests: cortex $\mathrm{K}+$ yellow, UV-; medulla $\mathrm{K}+$ yellow $\rightarrow$ blood red, C- or C+ slowly yellowish, 
$\mathrm{KC}+$ orange, $\mathrm{P}+$ yellow $\rightarrow$ orange, $\mathrm{UV}+$ yelloworange. Some orange patches are present, $\mathrm{K}+$ yellow $\rightarrow$ blood red.

TLC: atranorin, salazinic acid, consalazinic acid, lichexanthone, and unidentified substance of Rf 49 in solvent $\mathrm{C}$.

Distribution: Brazil (Marcelli 2004), where it was recorded to PR (Kurokawa 1974, Fleig 1997), RJ (Kurokawa 1974), RS (Spielmann 2006), SC (Fleig 1997) and SP (Fleig 1997, Ribeiro 1998).

Specimens examined: BRAZIL. Rio Grande do SuL: Boqueirão do Leão, Linha Sinimbuzinho, Perau da Nega, 29²0'17.2" S, 52²6'33.6” W, 430 m alt., on the steep slope in the left side of the stream, partially shaded, 22-II-2004, A.A. Spielmann \& L.S. Canêz 1161 (SP), A.A. Spielmann \& L.S. Canêz. 1162 (SP).

Parmotrema spinibarbe is distinguished by the ciliate lobes, sorediose pustules, presence of salazinic acid and lichexanthone (medulla $\mathrm{K}+$ yellow $\rightarrow$ blood red, UV+ yellow-orange), and imperforate apothecia. Two other similar species share the same chemistry: P. ultralucens (Krog) Hale has isidia instead of soredia and longer ascospores,15-17 × 10-12 $\mu \mathrm{m}$ (Krog 1974), and in P. lichexanthonicum Eliasaro \& Adler the vegetative propagules are lacking (Eliasaro \& Adler 1997).

Eliasaro \& Adler (1997) stated that $P$. lichexanthonicum could be the parental species of $P$. ultralucens. Yet, P. ultralucens has imperforate apothecia, while in $P$. lichexanthonicum they are perforate. According to Hale (1965), species pairs with these distinct features are not known. So maybe this is the first report.

Parmotrema subrugatum (Kremp.) Hale, Phytologia 28(4): 339. 1974 = Parmelia subrugata Kremp., Verh. Zool. Bot. Gesell. Wien 18: 320. 1868. Type: BRAZIL. Rio DE JANEIRO: Serra dos Órgãos, Helmreichen s.n. (holotype M, isotype US), fide Hale (1965) and Fleig (1997).

Figure 33

Thallus greenish gray, lobate, subascendant, coriaceous, corticicolous, $10 \mathrm{~cm}$ broad. Lobes irregularly branched, crowded, 5-7 cm wide, median axis subascendant or extended, surface smooth to slightly rugose-scrobiculate, becoming strongly rugose-scrobiculate in the center; apical zone subconcave, undulate, margin entire to sublacinulate; lateral marginal zone undulate, ascendant, margin sublacinulate to lacinulate. Lacinules dichotomous or digitate, subcanaliculate, $1.0-20 \times 0.2-3.0$ $\mathrm{mm}$, branching several times, evenly distributed, margin involute, apex truncate or acute; maculae distinct, punctiform, laminal, marginal or in the amphithecium. Cilia black, simple, bifurcated or irregularly branched, $0.5-2.0 \times 0.05 \mathrm{~mm}$, frequent, evenly distributed. Pustules, soredia and isidia absent. Medulla white. Lower surface black, lustrous, smooth to rugose; marginal zone ivory white, or sometimes pale brown, 5-10 mm wide, nude, opaque to lustrous, with a sharp limit, smooth to rugosereticulate or veined close to the apothecia. Rhizines black, simple, tortuous, $0.50-1.50 \times 0.02-0.05 \mathrm{~mm}$, abundant, dispersed in groups. Apothecia urceolate to patent, stipitate, $4-10 \mathrm{~mm}$ in diameter, laminal, frequent, base wide, rugose, amphithecium splitted, involute, clearly rugose and maculate, sometimes with digitate projections, margin digitate or fimbriate, without cilia, disc pale ochre, concave to cupulate, epruinose, imperforate; epithecium 12.5-30.0 $\mu \mathrm{m}$; hymenium $60-80 \mu \mathrm{m}$; subhymenium $25-40 \mu \mathrm{m}$; ascospores ellipsoid, narrow-ellipsoid or slightly reniform, (17.5-) 25.0-34.0 × 15-19 $\mu \mathrm{m}$, episporium 2.5-4.0 $\mu \mathrm{m}$. Pycnidia laminal or more commonly submarginal to marginal, conspicuous, ostiole black; conidia unciform, 4.0-5.5 × ca. $1.0 \mu \mathrm{m}$.

Color tests: cortex $\mathrm{K}+$ yellow, $\mathrm{UV}-$; medulla $\mathrm{K}-, \mathrm{C}-$, $\mathrm{KC}+$ rose $\rightarrow$ quickly orange, $\mathrm{P}-, \mathrm{UV}+$ greenish blue.

TLC: atranorin, alectoronic acid and $\alpha$-collatolic acid.

Distribution: Oceania (Hale 1965, Elix 1994, Louwhoff \& Elix 1999), Asia, Africa (Hale 1965, Kurokawa \& Lai 2001) and Americas (Hale 1965). In South America it is known to Argentina (Hale 1965, Calvelo \& Liberatore 2002), Brazil (Marcelli 2004) and Uruguay (Osorio 1972). In Brazil it was recorded to MG (Hale 1965, Fleig 1997, Ribeiro 1998), PA (Brako et al. 1985, as Parmotrema cf. subrugatum), PR (Osorio 1977a/b, Eliasaro 2001), RJ (Hale 1965), RS (Spielmann 2006) and SP (Ribeiro 1998).

Specimens examined: BRAZIL. Rio GRANDE DO SuL: Sobradinho, margin from RST-481, next to the crossroads, $29^{\circ} 24^{\prime \prime} 20.2^{\prime \prime} \mathrm{S}, 53^{\circ} 01^{\prime} 25.9^{\prime \prime} \mathrm{W}, 375 \mathrm{~m}$ alt., open place, 17-VII-2003, A.A. Spielmann 360 (SP).

Parmotrema subrugatum is recognizable by the unciform conidia, the presence of alectoronic acid 
(medulla $\mathrm{KC}+$ rose $\rightarrow$ quickly orange, $\mathrm{UV}+$ greenish blue), apothecia imperforate, ascospores large (up to $34 \mu \mathrm{m})$, the lower ivory white margin and the absence of vegetative propagules. Parmotrema wainioi (A.L. Smith) Hale has a brown lower margin, bacillar to filiform conidia and smaller ascospores (up to 22 $\mu \mathrm{m}$ according to Vainio 1890). In P. argentinum (Kremp.) Hale, the conidia are bacillar (Fleig 1997), the apothecia often ciliate, ascospores with up to $22 \mu \mathrm{m}$ (Hale 1965). P. rigidum (Lynge) Hale has filiform conidia and perforate apothecia. Finally, in P. laciniatulum Krog the conidia are sublageniform (Krog 1991).

Apparently $P$. subrugatum is the only known species of Parmotrema with unciform conidia. However, the literature about is very unclear. Vainio (1890) described the conidia as cylindrical 4-5 $\times$ $1 \mu \mathrm{m}$. Zahlbruckner (1926b) as bacillar, 3.8-6.5 $\times$ $0.5-0.7 \mu \mathrm{m}$. In this paper specimens from Brazil collected by Weddel revealed bacillar and slightly arcuate conidia, 2.5-5.0 × 0.6-0.7 $\mu \mathrm{m}$. Based on the type of conidia found (cylindrical, arcuate and apical zone, 4-5 × $0.5 \mu \mathrm{m}$ ), Lynge (1914) proposed Parmelia subrugata var. arcuata. Hale (1965) stated that the conidia of Parmelia subrugata were not seen, although before (Hale 1960) he found that the holotype presented conidia more or less arcuate, identical to that described by Lynge (1914). Fleig (1997) found unciform conidia, 5-8 (-9) $\mu \mathrm{m}$ long. In Elix (1994) and Louwhoff \& Elix (1999) they are bacillar, 4-5 × $1 \mu \mathrm{m}$. Finally, Eliasaro (2001) found cylindrical a sublageniform, straight or slightly curved conidia, 5-8 $\mu \mathrm{m}$ long.

The specimen studied here is very similar to the holotype picture published by Hale (1965), where the strongly rugose apothecia and lacinulate lobes are sharply distinct.

Parmotrema tinctorum (Dèspr. ex Nyl.) Hale, Phytologia 28(4): 339.1974 $\equiv$ Parmelia tinctorum Dèspr. ex Nyl., Flora 55: 547. 1872. Type: CANARY ISLANDS. Dèspréaux s.n. (holotype H-NYL35365), fide Fleig (1997).

Figure 35

Thallus pale to mineral gray, lobate, membranaceous, subcoriaceous or coriaceous, loosely adnate, corticicolous or saxicolous, 6-28 $\mathrm{cm}$ broad. Lobes irregularly branched, laterally overlapping or slightly crowded, (3-) 4-22 (-25) mm wide, surface smooth, opaque to lustrous, becoming rugose and cracked in the center; apical zone plane to subconcave, undulate; margin entire to crenate; lateral marginal zone undulate, subascendant to ascendant, more or less imbricate, involute, margin entire to crenate. Lobules sometimes present, laminal or marginal, $0.20-4.00 \times 0.20-4.00 \mathrm{~mm}$. Lacinules, cilia, pustules and soralia absent. Maculae usually absent, when present weak or distinct, laminal. Isidia with base concolor to the thallus or rarely brownish, apex pale or dark brown, simple to branched or sometimes forming coralloid aggregates 1.0-1.5 $\mathrm{mm}$ in diameter, narrow, granular or coalescing and coarsely granular, sometimes becoming sorediose, or papillary at young, erect, firm or caducous, starting in the crests or fissures, then becoming laminal, usually more dense in the central areas, $0.05-0.50$ $\times 0.05-0.30 \mathrm{~mm}$. Medulla white. Lower surface black, opaque or lustrous, rugose; marginal zone brown, brown and black variegated or sometimes entirely black, nude, lustrous or rarely opaque, with a sharp or attenuate limit, smooth, rugose, papillate or veined, (2.5-) 4.0-12.0 mm wide. Rhizines black or rarely brown at the margin, simple or furcated, sometimes with as flatted apices, $0.10-3.00 \times 0.05-$ $0.20 \mathrm{~mm}$, frequent to few, dispersed in small groups or almost evenly. Apothecia absent [according to Hale (1965), up to $20 \mathrm{~mm}$ in diameter, excipulum isidiate-dentate, amphithecium rugose, maculate, isidiate, disc imperforate; ascospores 13-15 × 7-10 $\mu \mathrm{m}$, episporium $1.5 \mu \mathrm{m}]$. Pycnidia rare, submarginal, ostiole black; conidia filiform, straight or arcuate, (7.5-) 9.0-16.5 (-17.5) × ca. $1.0 \mu \mathrm{m}$.

Color tests: cortex $\mathrm{K}+$ yellow, $\mathrm{UV}-$; medulla $\mathrm{K}-, \mathrm{C}+$ red, $\mathrm{KC}+$ red, $\mathrm{P}-$, UV-.

TLC: atranorin, lecanoric acid.

Distribution: Oceania (Hale 1965, Elix 1994, Malcolm \& Galloway 1997, Louwhoff \& Elix 1999), Asia (Hale 1965, Awasthi 1976, Kurokawa 1991b, 1993 , Kurokawa \& Lai 2001, Louwhoff \& Elix 2000, 2002), Europe (Purvis et al. 1992), Africa (Hale 1965, Winnem 1975, Krog \& Swinscow 1981, Swinscow $\&$ Krog 1988) and Americas (Hale 1965). In South America it is known to Argentina (Hale 1965, Calvelo \& Liberatore 2002), Brazil (Marcelli 2004), Chile (Feuerer 2005), Colombia, Ecuador (Hale 1965), Guyana, French Guiana (Feuerer 2005), Peru (Hale 1965), Paraguay (Lynge 1914, Hale 1965), Uruguay (Osorio 1972) and Venezuela (Vareschi 1962, 1973, 
Dennis 1965, Hale 1965). In Brazil it was recorded to MG (Lynge 1914, Hale 1965, Fleig 1997, Ribeiro 1998), MS (Fleig \& Riquelme 1991, Osorio 1992b), MT, RJ (Lynge 1914, Hale 1965, Fleig 1997), PA (Brako et al. 1985), PR (Osorio 1977a/b, Eliasaro 2001), RS (Spielmann 2006), SC (Fleig 1997) and SP (Hale 1965, Osorio 1989, Nagaoka \& Marcelli 1989, Pereira \& Marcelli 1989, Marcelli 1991, Ribeiro 1998).

Specimens examined: BRAZIL. Rio GRANDE do SuL: Boqueirão do Leão, Linha Sinimbuzinho, Perau da Nega, 29²0’02.2”'S, 52²6’27.9”'W, 440 m alt., stream's margin and close to the street, shaded place, 24-II-2004, A.A. Spielmann \& L.S. Canêz 1257 (SP); Herveiras, $29^{\circ} 25^{\prime} 53.7$ 'S, 52 ${ }^{\circ} 40^{\prime} 19.6$ 'W, $570 \mathrm{~m}$ alt., open place, 20-I-2004, A.A. Spielmann \& J. Putzke 1260 (SP); idem, 24-I-2004, A.A. Spielmann, L.S. Canêz \& C. Trentin 932 (SP), A.A. Spielmann et al. 970 (SP); Santa Cruz do Sul, margin from RST-287, Km 102, 2941'03.3'S, 52²5'33.6”'W, 150 m alt., open place, 28-VII-2003, A.A. Spielmann 384 (SP); idem, on Eucalyptus trunk, open place, 28-VII-2003, A.A. Spielmann 397 (SP); Sinimbu, Cava Funda, 2927'41.8'S, 52³1'11.7' W, $500 \mathrm{~m}$ alt., open place, 12-II-2003, A.A. Spielmann 62 (SP), A.A. Spielmann 100 (SP); idem, open place, 12-II-2003, A.A. Spielmann 98 (SP); idem, open place, 12-II2003, A.A. Spielmann 113 (SP); idem, 29²7’33.4”S, $52^{\circ} 31^{\prime} 05.1^{\prime \prime} \mathrm{W}, 520 \mathrm{~m}$ alt., open place, 5-I-2004, A.A. Spielmann \& L.S. Canêz 1255 (SP); idem, 29'27'33.4'S, 52 31'05.1'W, 520 m alt., with mosses, open place, 5-I-2004, A.A. Spielmann \& L.S. Canêz 1256 (SP); Sobradinho, margin from RST-481, next to the crossroads, $29^{\circ} 24^{\prime} 20.2^{\prime \prime} \mathrm{S}, 5^{\circ} 01^{\prime} 25.9^{\prime \prime} \mathrm{W}, 375$ $\mathrm{m}$ alt., open place, 17-VII-2003, A.A. Spielmann 354 (SP); idem, 17-VII-2003, A.A. Spielmann 357 (SP).

Parmotrema tinctorum is distinguished by the isidiate thallus, broad $(4-22 \mathrm{~mm})$ and eciliate, and the presence of lecanoric acid (medulla $\mathrm{C}+$ red). The apothecia are rare and imperforate (Hale 1965). Parmotrema stuhlmanii (C.W. Dodge) Krog \& Swinscow has narrower lobes $(6-8 \mathrm{~mm})$ and perforate apothecia (Krog \& Swinscow 1981), while $P$. pseudotinctorum (Abbayes) Hale has inflated isidia $0.5 \times 0.2-0.3 \mathrm{~mm}$ (Hale 1965). In P.internexum (Nyl.) Fleig, the medulla presents norlobaridone and stictic acid $(\mathrm{K}+$ yellow).

This was the more common species found in the studied area, so commonly reported (see (Spielmann
2006) at the point to be called "weedy" (Hale 1965). A very wide morphological variation is admitted, from cylindrical or coralloid isidia to isidia becoming sorediose. Maybe more taxa are being wrongly named and a revision of this group would be very welcome.

Parmotrema tinctorum is often authored as "(Nyl.) Hale", i.e., without Dèspréaux. Here we agree with Lynge (1914), Krog \& Swinscow (1981), Louwhoff \& Elix (1999), Hale \& DePriest (1999) and Hawksworth (2004), since Nylander (1872) admitted the Dèspréaux as the author of this species (se also the Vienna Code Art. 46.4, in MacNeill et al. 2007).

The specimens Spielmann 113 and Spielmann 354 are maculate. This feature is rarely found in the literature (just Galloway 1985), as well as the presence of lobules, reported by Krog \& Swinscow (1981) and also observed in our specimens.

Parmotrema wainioi (A.L. Smith) Hale, Phytologia 28(4): 339. 1974 三 Parmelia wainii A.L. Smith, Journal of the Linnean Society, London, Botany 46: 85. 1922. Type: BRAZIL. Minas Gerais: Caraça, Vainio, Lichenes Braziliensis exsiccati ${ }^{\circ} 400$ (holotype TUR-V2410), fide Fleig (1997).

Figures 36, 38

Thallus pale gray, lobate, membranaceous to subcoriaceous, loosely adnate, corticicolous or saxicolous, $8.0-11.5 \mathrm{~cm}$ broad. Lobes irregular, laterally overlapping to crowded, 3-20 mm wide, surface smooth to irregular or scrobiculate, opaque to lustrous, becoming rugose or reticulate cracked in the center; apical zone plane to subconcave, ascendant, involute or revolute, undulate, margin entire to crenate or incise-crenate (sublacinulate); lateral marginal zone undulate, ascendant to imbricate, margin irregular to crenate or sometimes lacinulate. Lacinules plane to subcanaliculate, simple or furcated, evenly distributed, with rounded, truncate or acute apex, 2-15 × 2-12 mm, lower surface black or brown; maculae absent. Cilia black or sometimes red pigmented (then $\mathrm{K}+$ purplish), usually simple, rarely furcated or irregular-branched (figure 38), 0.20-3.00 $\times$ 0.05-0.10 mm, abundant, evenly distributed. Pustules, soredia and isidia absent. Medulla white. Lower surface black, lustrous, smooth to rugose; marginal zone brown to pale brown, lustrous, 1-6 mm wide, with a sharp or attenuate limit, smooth, rugose, papillate-rhizinate, scrobiculate, with veins or with small ridges (relatives to the foveolae from 
the upper surface). Rhizines black, simple, furcated or irregularly branched, $0.20-2.50 \times 0.02-0.10 \mathrm{~mm}$, abundant, evenly distributed but more dense in some areas. Apothecia absent [according to Vainio (1890, as Parmelia proboscidea), 5-20 $\mathrm{mm}$ in diameter, cupulate, sessile to substipitate, imperforate, margin entire or crenulated, excipulum reticulate-rugose, ascospores 14-22 × 9-12 $\mu \mathrm{m}]$. Pycnidia submarginal to laminal, conspicuous, with prominent margin, ostiole black; conidia bacillar to filiform, straight or arcuate, $6.0-12.5 \times$ ca. $1.0 \mu \mathrm{m}$.

Color tests: upper cortex $\mathrm{K}+$ yellow, $\mathrm{UV}-$; medulla $\mathrm{K}-, \mathrm{C}-, \mathrm{KC}+$ rose $\rightarrow$ quickly orange, $\mathrm{P}-, \mathrm{UV}+$ greenish blue.

TLC: atranorin, $\alpha$-alectoronic, $\alpha$-collatolic and an unidentified substance of Rf 31 in solvent $\mathrm{C}$.

Distribution: Oceania, Africa (Feuerer 2005) and South America (Hale 1965). In South America it is known to Brazil (Marcelli 2004), where it was recorded to MG (Vainio 1890, as Parmelia proboscidea Taylor, Hale 1965, Fleig 1997, Ribeiro 1998), PR (Fleig 1997, Eliasaro 2001), RJ, GO? (Fleig 1997), RS (Spielmann 2006), SC (Fleig 1997) and SP (Ribeiro 1998).

Specimens examined: BRAZIL. Rio Grande do Sul: Herveiras, 29²5'53.7'S, 5240'19.6”'W, 570 m alt., on Eucalyptus trunk, open place, 24-I-2004, A.A. Spielmann \& J. Putzke 728 (SP); Sinimbu, Cava Funda, 29²7'31.6”'S, 52³1'02.9”'W, $520 \mathrm{~m}$ alt., open place, 5-I-2004, A.A. Spielmann \& L.S. Canêz 986 (SP).

Parmotrema wainioi is recognizable by the presence of alectoronic acid (medulla UV+ greenish blue), bacillar to filiform conidia and the absence of vegetative propagules. P. pseudobreviciliatum Adler, Elix \& Hale has shorter cilia, up to $2.5 \mathrm{~mm}$ long (Adler 1989). And in P. subrugatum the conidia are unciform.

The epithet "wainii" is in disagreement with the recommendation 60C.1 of the Vienna Code (McNeill et al. 2007), since the end should be "oi". Ribeiro (1998) proposed "vainioi", since from 1919 Wainio changed his last name to Vainio (Alava 1998). Nevertheless, the article 60.1 asserts that "the original spelling of a name or epithet is to be retained", and the article 60.11 , together with the recommendation 60C.1, deal with just the ends of the epithets, the correct spelling therefore is "wainioi".
Group III - Rimelia-like lichens (species with reticulate maculae and rhizines often reaching the margin, without dimorphic rhizines, belonging to Rimelia sensu Hale \& Fletcher)

A comparative table to known species was made, based mainly on the following references: Brodo et al. (2001), Canêz (2005), Eliasaro (2001), Eliasaro \& Adler (1998), Elix et al. (2002), Esslinger (1972), Fleig (1997), Hale (1971a), Hale \& Fletcher (1990), Louwhoff \& Elix (1998), Marcelli \& Ribeiro (2002), Mata García (1994), Moon et al. (2001) and Ribeiro (1998)

Parmotrema cetratum (Ach.) Hale, Phytologia 28(4): 335. $1974 \equiv$ Parmelia cetrata Ach., Synopsis Methodica Lichenum: 198. 1814 = Rimelia cetrata (Ach.) Hale \& Fletcher, The Bryologist 93(1): 26. 1990. Type: UNITED STATES OF AMERICA. Pennsylvania: Muhlenberg s.n. (lectotype H-ACH, selected by Hale \& Fletcher 1990, isolectotype UPS), fide Hale \& Fletcher (1990).

Figure 4

Thallus greenish gray, lobate, loosely adnate, corticicolous, saxicolous or muscicolous, 4.5-8.0 $\mathrm{cm}$ broad. Lobes irregularly branched, laterally overlapping to crowded, $2.5-7.0 \mathrm{~mm}$ wide, median axis extended to subascendant, surface smooth to slightly rugose, usually undulate or subscrobiculate, opaque to slightly lustrous, becoming rugose and reticulate cracked towards de center; apical zone subconcave, plane to ascendant, undulate; margin entire to incise-crenate (sublacinulate); lateral marginal zone plane to more often ascendant, margin lacinulate. Lacinules furcated, dichotomous or irregularly branched, 2.0-20.0 × 0.5-3.5 mm, plane to canaliculated and usually revolute, apex acute or sometimes truncate, lower surface black with brown margin, evenly distributed; maculae distinct, reticular, laminal, forming cracks. Cilia black, simple to squarrose, $0.20-2.00 \times 0.02-0.05 \mathrm{~mm}$, frequent to few, evenly distributed. Pustules, soredia and isidia absent. Medulla white. Lower surface black, lustrous, smooth, rugose or veined; marginal zone brown, 1.5-5.0 $\mathrm{mm}$ wide, lustrous, rhizinate, with attenuate limit, smooth to veined or scrobiculate. Rhizines black, usually simple, sometimes irregularly branched, $0.10-1.00 \times 0.01-0.05 \mathrm{~mm}$, abundant, evenly distributed. Apothecia urceolate, 2-15 $\mathrm{mm}$ in diameter, stipitate, submarginal, margin smooth or incise, amphithecium maculatereticulate, smooth to slightly scrobiculate or rugose, 
Table 3. Correspondence between morphological structures and the presence of medullar substances in Rimelia-like lichens.

\begin{tabular}{|c|c|c|c|c|c|}
\hline MEDULLAR SUBSTANCES & $\begin{array}{c}\text { WITHOUT } \\
\text { VEGETATIVE } \\
\text { PROPAGULES }\end{array}$ & SOREDIATE & ISIDIATE & PUSTULATE & $\begin{array}{l}\text { WITH SCHIZIDIA } \\
\text { OR DACTYLS }\end{array}$ \\
\hline $\begin{array}{l}\text { SALAZINIC AND CONSALAZINIC } \\
\text { ACIDS }\end{array}$ & $\begin{array}{l}P . \text { cetratum } \\
P . \text { ramescens }\end{array}$ & $\begin{array}{l}\text { P. albinata } \\
P . \text { clavulifera } \\
\text { P. commensurata }( \pm) \\
\text { P. pontagrossensis } \\
\text { P. reticulatum }\end{array}$ & $\begin{array}{l}\text { P. lacteum } \\
\text { P. subisidiosum }\end{array}$ & $\begin{array}{l}\text { P. pustulatum } \\
\text { P. ruminatum }\end{array}$ & $\begin{array}{l}\text { P. austrocetratum } \\
\text { P. hawaiiensis }\end{array}$ \\
\hline PROTOCETRARIC ACID & & P. succinreticulatum & & & $\begin{array}{l}\text { P. austrocetratum } \\
( \pm \text { trace })\end{array}$ \\
\hline FUMARPROTOCETRARIC ACID & & P. succinreticulatum & & & \\
\hline STICTIC ACID AND ALLIED & P. sticticum & & & & \\
\hline LOXODIN & P. homotomum & & & & \\
\hline NORLOBARIDONE & P. homotomum & P. commensuratum & P. bonplandii & & \\
\hline GYROPHORIC ACID & $\begin{array}{l}\text { P. cetratum } \\
\text { (accessory) }\end{array}$ & $\begin{array}{l}\text { P. clavuliferum } \\
\text { (accessory) }\end{array}$ & & & \\
\hline LICHEXANTHONE & & $\begin{array}{l}\text { P. diffractaicum } \\
\text { P. pontagrossensis }\end{array}$ & P. bonplandii & & \\
\hline DIFFRACTAIC ACID & & P. diffractaicum & & & \\
\hline LOBARIC ACID & & P. albinatum (trace) & & & \\
\hline MENEGAZZIAIC ACID & P. sticticum & & & & \\
\hline CAPERATIC ACID & P. macrocarpum & P. simulans & & & \\
\hline FAT ACIDS & & $\begin{array}{l}\text { P. clavuliferum } \\
\text { P. succinreticulatum }\end{array}$ & & & \\
\hline
\end{tabular}

disc brown, epruinose, perforate, usually involute and splitted; epithecium 5-10 $\mu \mathrm{m}$; hymenium 40-55 $\mu \mathrm{m}$; subhymenium 15-30 $\mu \mathrm{m}$; ascospores ellipsoid, 8.5-15.0 × 5.0-10.0 $\mu \mathrm{m}$, episporium ca. 1 $\mu \mathrm{m}$. Pycnidia laminal to submarginal or sometimes reaching the margin, present mainly on the lacinules, conspicuous, usually with prominent margin, ostiole black; conidia filiform, 10.0-17.5 × ca. $1.0 \mu \mathrm{m}$.

Color tests: cortex $\mathrm{K}+$ yellow, UV-; medulla $\mathrm{K}+$ yellow $\rightarrow$ blood red, $\mathrm{C}+$ slowly yellowish or orange, $\mathrm{KC}+$ orange, $\mathrm{P}+$ yellow $\rightarrow$ orange, $\mathrm{UV}-$.

TLC: atranorin, salazinic and consalazinic acids.

Distribution: Oceania (Elix 1994, Galloway 1985, Malcolm \& Galloway 1997, Louwhoff \& Elix 1999), Asia (Awasthi 1976, Kurokawa \& Lai 2001), Africa (Krog \& Swinscow 1981, Swinscow \& Krog 1988, Hale \& Fletcher 1990, Aptroot 1991), North America
(Hale \& Fletcher 1990, Brodo et al. 2001, Nash \& Elix 2002b, Esslinger 2008), Central America (Feuerer 2005) and South America (Hale \& Fletcher 1990). In South America it is known to Argentina (Lynge 1925, Osorio 1976, Hale \& Fletcher 1990, Adler 1992, Calvelo \& Liberatore 2002), Bolivia (Lynge 1925, Feuerer et al. 1998), Brazil (Marcelli 2004), Chile (Feuerer 2005), Paraguay (Lynge 1914), Peru (Feuerer 2005), Uruguay (Lynge 1925; Osorio 1972, 1992a, 1995, 2003) and Venezuela (Vareschi 1973). In Brazil it was recorded to MG (Lynge 1914, 1925; Hale \& Fletcher 1990, Ribeiro 1998), MT (Lynge 1914), PR (Osorio 1977a/b, Fleig 1997, Eliasaro 2001), RJ (Lynge 1925), RS (Spielmann 2009), SC (Marcelli 1992, Osorio 1997, Fleig 1997) and SP (Marcelli 1991, 1992; Ribeiro 1998).

Specimens examined: BRAZIL. Rio Grande Do Sul: Boqueirão do Leão, Cascata do Gamelão, $29^{\circ} 18^{\prime} 13.7^{\prime \prime} \mathrm{S}, 52^{\circ} 26^{\prime} 51.7^{\prime \prime} \mathrm{W}, 500 \mathrm{~m}$ alt., right side of 
the stream, open place, 31-I-2004, A.A. Spielmann \& M.A. Sulzbacher 1289 (SP); Herveiras, 29²5'53.7'S, $52^{\circ} 40^{\prime} 19.6$ "W, $570 \mathrm{~m}$ alt., with mosses, open place, 21-I-2004, A.A. Spielmann et al. 697 (SP); idem, on Eucalyptus trunk, open place, 24-I-2004, A.A. Spielmann et al. 717 (SP); Sinimbu, Cava Funda, 29०27'41.8”'S, 52॰31'11.7W, $500 \mathrm{~m}$ alt., open place, 4-II-2003, A.A. Spielmann 63 (SP); idem, $29^{\circ} 27^{\prime} 33.4^{\prime \prime} \mathrm{S}, 52^{\circ} 31^{\prime} 05.1^{\prime \prime} \mathrm{W}, 520 \mathrm{~m}$ alt., open place, 5-I-2004, A.A. Spielmann \& L.S. Canêz 752 (SP); idem, Linha Almeida, 29²3'20.2”'S, 52³0'21.9”'W, 5-I-2004, A.A. Spielmann \& L.S. Canêz 1292 (SP).

Parmotrema cetratum is recognizable by the absence of vegetative propagules and the production of salazinic acid (medulla $\mathrm{K}+$ yellow $\rightarrow$ blood red). Some similar species can be distinguished: P. austrocetratum Elix \& Johnston is a lacinulate, develops schizidia and has filiform conidia up to $25 \mu \mathrm{m}$ long (holotype CHR!); P. hawaiiensis (H. Magn.) Blanco, Crespo, Divakar, Elix \& Lumbsch also bear schizidia, but the conidia are just up to 15 $\mu \mathrm{m}$ long and the lacinules lacking (holotype $\mathrm{S}$ !); $P$. homotomum presents norlobaridone and loxodin (medulla $\mathrm{K}-, \mathrm{KC}+$ rose or reddish) and finally $P$. macrocarpum (Pers.) Hale has just caperatic acid (Fleig 1997).

According to the current literature, $P$. cetratum shows a wide range of morphological variation, maybe a consequence of too broad species concepts, clearly seen by the long list of synonyms attributed to this species (see Hale \& Fletcher 1990).

Galloway (1985) reported several morphological differences between specimens from coastal rocks and from wood or bark inland. Fleig (1997) recognized three distinct groups of species, based on thallus shape. Interestingly, Moon et al. (2001), studying material from Hawaii, also established three groups, adding features from cilia and substrate preferences, and that correspond to Fleig's groups. These patterns maybe are indicative of specific variation, not just environmental modifications

Parmotrema clavuliferum (Räs.) Streimann, Bibliotheca Lichenologica 22: 93. 1986 三 Parmelia clavulifera Räs., Annales Botanici Societatis Zoologicae Botanicae Fennicae 20(3): 4.1944 = Rimelia clavulifera (Räs.) Kurok., Journal of Japanese Botany 66(3): 158. 1991. Type: TAHITI. Vieillard s.n. (lectotype H, selected by Hale \& Fletcher 1990), fide Hale \& Fletcher (1990).

Figures 5-7
Thallus pale gray, lobate, membranaceous, loosely adnate, saxicolous or muscicolous, 6.5$22 \mathrm{~cm}$ broad. Lobes irregularly branched, laterally overlapping, subpalmate-lacinulate, 2-12 $\mathrm{mm}$ wide, surface smooth, opaque to sublustrous, usually pruinose, becoming reticulate cracked in the center; apical zone plane to subconcave, undulate, margin crenate to sublacinulate; lateral marginal zone usually undulate and ascendant, margin usually lacinulate. Lacinules simple to furcated, $0.5-2.0 \times 0.2-1.5 \mathrm{~mm}$, plane to canaliculated, apex acute to truncate, evenly distributed, lower surface white variegated under the soralia; maculae distinctly, reticular, laminal, forming cracks. Cilia black, simple or sometimes squarrose, $0.50-2.00 \times 0.02-0.05 \mathrm{~mm}$, frequent to abundant, but infrequent in the sorediate parts, evenly distributed. Pustules and isidia absent. Soralia labriform, capitate or orbicular, present in the lacinules apices or sometimes submarginal; soredia farinose to granular. Medulla white. Lower surface black, lustrous, smooth; marginal zone dark brown, white variegated under the soralia, 1-2 mm wide, lustrous, nude or with rhizines, with attenuate limit, smooth to papillate or slightly rugose. Rhizines black, simple, furcated or squarrose, $0.2-2.5 \times 0.01-0.15 \mathrm{~mm}$, abundant, evenly distributed, sometimes groups of thickened rhizines can be seen. Apothecia unknown. Pycnidia submarginal to laminal, few to rare, conspicuous, without prominent margin, ostiole black; conidia bacillar to filiform, 7.5$12.5 \times$ ca. $1.0 \mu \mathrm{m}$.

Color tests: cortex $\mathrm{K}+$ yellow, $\mathrm{UV}-; \mathrm{K}+$ yellow $\rightarrow$ blood red, $\mathrm{C}+$ slowly yellowish or $\mathrm{C}-, \mathrm{KC}+$ orange, $\mathrm{P}+$ yellow $\rightarrow$ orange, $\mathrm{UV}-$.

TLC: atranorin, salazinic and consalazinic acids.

Distribution: Oceania (Lamb 1963, Feuerer 2005), Asia (Feuerer 2005), Hawaii (Moon et al. 2001) and Brazil (Barros \& Xavier Filho 1972).

Specimens examined: BRAZIL. Rio GRANDE do SUL: Barros Cassal, 2907'05.4'S, 5241'19.9'W, open place, 24-I-2004, A.A. Spielmann et al. 725 (SP); Boqueirão do Leão, Linha Sinimbuzinho, Perau da Nega, 29'20'17.2" S, 52²6'33.6" W, 430 m alt., open place, 23-II-2004, A.A. Spielmann \& L.S. Canêz 1347 (SP), A.A. Spielmann \& L.S. Canêz 1359 (SP); idem, $29^{\circ} 20^{\prime} 02.2^{\prime \prime S}, 52^{\circ} 26^{\prime} 27.9$ 'W, $440 \mathrm{~m}$ alt., slightly shaded, 24-II-2004, A.A. Spielmann \& L.S. Canêz 722 (SP); Herveiras, 2925'53.7'S, 5240'19.6”'W, $570 \mathrm{~m}$ alt., muscicolous, open place, 24-I-2004, A.A. Spielmann et al. 683 (SP); idem, open place, 
20-I-2004, A.A. Spielmann \& J. Putzke 1303 (SP);

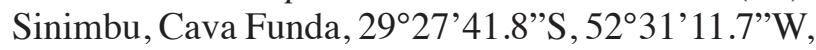
$500 \mathrm{~m}$ alt., open place, 12-II-2003, A.A. Spielmann 36 (SP); idem, $29^{\circ} 27^{\prime} 33.4^{\prime \prime} \mathrm{S}, 52^{\circ} 31^{\prime} 05.1$ ”W, 520 $\mathrm{m}$ alt., open place, 5-I-2004, A.A. Spielmann \& L.S. Canêz 688 (SP); idem, 5-I-2004, A.A. Spielmann \& L.S. Canêz 745 (SP); idem, 5-I-2004, A.A. Spielmann \& L.S. Canêz 1305 (SP).

Parmotrema clavuliferum is distinguished by the sorediate lacinules (figure 6), white variegated lower margin under the soralia (figure 7), filiform conidia 7.5-12.5 $\mu \mathrm{m}$ long and the presence of salazinic $(\mathrm{K}+$ yellow $\rightarrow$ blood red). In $P$. reticulatum the soralia are laminal to submarginal (Moon et al. 2001) and the conidia 12-16 $\mu \mathrm{m}$ (Hale \& Fletcher 1990). Parmotrema pseudoreticulatum (Tavares) Hale has a nude and brown lower margin, 2-4 mm wide (Tavares 1945), P. commensuratum produces norlobaridone and loxodin $(\mathrm{K}-, \mathrm{KC}+$ rose $\rightarrow$ reddish $)$ and $P$. simulans only caperatic acid (negative reactions).

Parmotrema commensuratum (Hale) Hale.Phytologia 28(4): 335.1974 = Parmelia commensurata Hale, Phytologia 22(1): 31. 1971 三 Rimelia commensurata (Hale) Hale \& Fletcher, The Bryologist 93(1): 27. 1990. Type: MEXICO. VERACRUZ: 9 Km E Jalapa, M.E. Hale 19405 (holotype US, isotypes TNS, UPS), fide Hale \& Fletcher (1990).

Figure 8

Thallus greenish gray, lobate, membranaceous, loosely adnate, corticicolous or saxicolous, 6.5-11.0 $\mathrm{cm}$ broad. Lobes irregularly branched, contiguous to crowded, 2-10 $\mathrm{mm}$ wide, surface smooth to scrobiculate, lustrous, sometimes pruinose, becoming reticulate cracked in the center; apical zone subconcave, margin ascendant to revolute, undulate, crenate to sublacinulate; lateral marginal zone undulate, ascendant, margin lacinulate. Lacinules simple to furcated, $0.5-3.5 \times 0.4-2.0 \mathrm{~mm}$, plane to canaliculate, apical zone, truncate or sometimes acute, evenly distributed; maculae distinct, reticular, laminal, forming cracks. Cilia black, usually simple, rarely furcated or irregularly branched, $0.20-1.50 \times$ 0.02-0.05 mm, few to frequent, evenly distributed. Pustules and isidia absent. Soralia orbicular to labriform, submarginal or in the lacinules apices, often approaching the lamina and turning the margins involute; soredia subgranular to granular. Medulla white. Lower surface black, lustrous, smooth to rugose; marginal zone brown, lustrous, 1.5-3.0 $\mathrm{mm}$ wide, usually densely rhizinate, with attenuate limit, smooth to papillate-rhizinate. Rhizines black, simple to squarrose, sometimes furcated or irregularly branched, $0.20-2.00(-3.00) \times 0.02-$ $0.05 \mathrm{~mm}$, abundant, evenly distributed and covering almost all the surface. Apothecia absent [according to Fleig (1997), urceolate, substipitate, submarginal, amphithecium sorediate]; ascospores unknown. Pycnidia submarginal, little conspicuous, rare, without prominent margin, ostiole black; conidia bacilliform to filiform, 7.5-10.0 $\times$ ca. $1.0 \mu \mathrm{m}$.

Color tests: cortex $\mathrm{K}+$ yellow, $\mathrm{UV}-$; medulla $\mathrm{K}-, \mathrm{C}-$, $\mathrm{KC}+$ rose $\rightarrow$ reddish, $\mathrm{P}-, \mathrm{UV}-$.

TLC: atranorin, norlobaridone and loxodin.

Distribution: Africa (Hale \& Fletcher 1990), North America (Hale 1971a, Dey 1974, Esslinger 2008), Central America (Hale 1971a), and South America (Feuerer 2005). In South America it is known to Brazil (Marcelli 2004), Colombia (Hale 1971a) and Venezuela (Feuerer 2005). In Brazil it was recorded to PR (Fleig 1997, Eliasaro 2001), RS (Spielmann 2006) and SC (Fleig 1997).

Specimens examined: BRAZIL. Rio GRANDE DO SuL: Sinimbu, Cava Funda, 29²7'41.8”'S, 52 31'11.7”'W, $500 \mathrm{~m}$ alt., open place, 4-II-2003, A.A. Spielmann 30 (SP); idem, 29²7'33.4'S, 52³1'05.1'W, 520 m alt., open place, 5-I-2004, A.A. Spielmann \& L.S. Canêz 1283 (SP); idem, Linha Almeida, 29²3'20.2”'S, 52 30'21.9'W, open place, 5-I-2004, A.A. Spielmann \& L.S. Canêz, 1299 (SP).

Parmotrema commensuratum is characterized by the soralia submarginal and in the lacinules apices and the presence of norlobaridone (medulla $\mathrm{K}-, \mathrm{KC}+$ rose $\rightarrow$ reddish). Parmotrema simulans (Hale) Hale has just caperatic acid (negative reactions) and $P$. clavuliferum presents salazinic acid (medulla $\mathrm{K}+$ yellow $\rightarrow$ blood red).

Parmotrema diffractaicum (Essl.) Hale, Phytologia 28(4): 335. 1974 三 Parmelia diffractaica Essl., The Bryologist 75(1): 80. 1972 = Rimelia diffractaica (Essl.) Hale \& Fletcher, The Bryologist 93(1): 27. 1990. Type: UNITED STATES OF AMERICA. Tennessee: Overton County, Cliff Springs, farm of M.T. Phillips, Phillips 308 (holotype US, isotype DUKE), fide Esslinger (1972). 
Figures 11-12

Thallus pale gray, lobate, membranaceous to subcoriaceous, loosely adnate, corticicolous or saxicolous, 7-15 $\mathrm{cm}$ broad. Lobes irregularly branched, laterally overlapping to crowded, 3-11 $\mathrm{mm}$ wide, surface smooth, lustrous, becoming reticulate cracked in the center; apical zone subconcave, undulate, plane or more frequently ascendant, margin crenate to sublacinulate; lateral marginal zone undulate, usually ascendant, involute when sorediate. Lacinules and isidia absent. Maculae weak to distinct, irregular, laminal. Cilia simple, "V" branched, cespitose or sometimes irregularly branched, $0.50-2.50 \times 0.02-0.05 \mathrm{~mm}$, evenly distributed. Pustules capitate, laminal, fragmenting in soredia. Soralia capitate to extensive, marginal to submarginal, or forming sorediose laminal pustules; when dense turning lobe margins involute; soredia granular. Medulla white. Lower surface black, lustrous, smooth to slightly rugose; marginal zone brown dark or rarely brown, lustrous, $1.5-4.5 \mathrm{~mm}$ wide, nude, with attenuate limit, smooth to papillate, sometimes rugose or with veins. Rhizines black, simple, squarrose or irregularly branched, 0.20$4.00 \times 0.02-0.10 \mathrm{~mm}$, abundant, dispersed in groups dense. Apothecia and pycnidia unknown.

Color tests: cortex $\mathrm{K}+$ yellow, $\mathrm{UV}-$; medulla $\mathrm{K}-, \mathrm{C}-$, $\mathrm{KC}-, \mathrm{CK}+$ orange, $\mathrm{P}-, \mathrm{UV}+$ yellow-orange.

TLC: atranorin, lichexanthone and diffractaic acid.

Distribution: North America (Esslinger 1972, Hale \& Fletcher 1990, Esslinger 2008) and South America, where it is known just to Brazil (Hale \& Fletcher 1990, Marcelli 2004). In Brazil it was recorded to MG (Marcelli \& Ribeiro 2002, as Rimelia luminosa), PR (Kurokawa 1985), RS (Spielmann 2006) and SC (Fleig 1997).

Specimens examined: BRAZIL. Rio GRANDE Do Sul: Boqueirão do Leão, Cascata do Gamelão, $29^{\circ} 18^{\prime} 13.7^{\prime \prime} \mathrm{S}, 52^{\circ} 26^{\prime} 51.7^{\prime \prime} \mathrm{W}, 500 \mathrm{~m}$ alt., on the steep slope at the left side of the stream, open place, 31-I-2004, A.A. Spielmann \& M.A. Sulzbacher 1089 (SP); Gramado Xavier, Nascente do Rio Pardinho, $29^{\circ} 14^{\prime} 15.0 " \mathrm{~S}, 52^{\circ} 31^{\prime} 14.3$ ” W, $625 \mathrm{~m}$ alt., on Araucaria angustifolia trunk, slightly shaded, 27-I2004, A.A. Spielmann et al. 1163 (SP).

Parmotrema diffractaicum is distinguished by the pustular to capitate soralia, the lower naked marginal zone (figure 12) and the presence of diffractaic acid (medulla CK+ orange) and lichexanthone (medulla UV+ yellow-orange). Parmotrema pontagrossense (Eliasaro \& Adler) Blanco, Crespo, Divakar, Elix $\&$ Lumbsch produces salazinic acid (medulla $\mathrm{K}+$ yellow $\rightarrow$ blood red) and $P$. bonplandii (Mata) Blanco, Crespo, Divakar, Elix \& Lumbsch is a similar, but isidiate species (Mata García 1994). Rimelia luminosa Marcelli (in Marcelli \& Ribeiro 2002) was recently recognized as a synonym of $P$. diffractaicum (Marcelli \& Canêz 2008).

Parmotrema homotomum (Nyl.) Hale, Phytologia 28(4): 336. 1974 三 Parmelia homotoma Nyl., Flora 68: 613. 1885 = Rimelia homotoma (Nyl.) Hale \& Fletcher, The Bryologist 93(1): 28. 1990. Type: BRAZIL. Rio DE JANEIRO: Organ Mountains, Weddell s.n. (lectotype H-NYL, selected by Hale \& Fletcher 1990), fide Hale \& Fletcher (1990) and Fleig (1997).

Figure 15

Thallus greenish gray, lobate, membranaceous, loosely adnate, corticicolous or saxicolous, 8.0$10.5 \mathrm{~cm}$ broad. Lobes irregularly branched, laterally overlapping to crowded, 2.0-15.0 mm wide, surface smooth to slightly scrobiculate, opaque to lustrous, becoming reticulate cracked in the center; apical zone plane to subconcave, ascendant or revolute, undulate, margin crenate to sublacinulate; lateral marginal zone usually ascendant and revolute, undulate, margin sublacinulate to lacinulate. Lacinules simple, furcated or irregularly branched, $1.0-6.0 \times 0.5-2.5 \mathrm{~mm}$, evenly distributed, plane to canaliculated or concave, with rounded or acute apex; maculae weak to distinct, reticular, laminal, forming cracks. Cilia black, simple to squarrose or sometimes furcated, $0.20-1.50 \times 0.02-0.06 \mathrm{~mm}$, frequent to abundant, evenly distributed. Pustules, soredia and isidia absent. Medulla white. Lower surface black, lustrous, smooth to rugose or papillate; marginal zone brown to dark brown, lustrous, $0.5-5.0 \mathrm{~mm}$ wide, with rhizines, with attenuate limit, smooth. Rhizines black, simple, squarrose or irregularly branched, 0.10-3.00 × 0.01-0.06 mm, sometimes robust and slightly thickened $(0.50-1.00 \times 0.05-0.10 \mathrm{~mm})$, dense and abundant, evenly distributed. Apothecia urceolate to slightly concave, usually laterally flatted, $1.5-9.5 \mathrm{~mm}$ in diameter, submarginal, stipitate, base constrict, margin smooth to dentate or shortdentate up to sublacinulate, amphithecium maculatereticulate, smooth to rugose or scrobiculate, disc 
brown, epruinose, perforate; epithecium 5.0-15.0 $\mu \mathrm{m}$; hymenium 35-60 $\mu \mathrm{m}$; subhymenium 15-35 $\mu \mathrm{m}$; ascospores ellipsoid, 10.0-16.5 × 6.5-10.0 $\mu \mathrm{m}$, episporium $0.7-1.2 \mu \mathrm{m}$. Pycnidia submarginal to laminal, conspicuous, usually with prominent margin, ostiole black; conidia bacillar to filiform, straight or slightly arcuate, 6.5-12.5 × $1.0 \mu \mathrm{m}$.

Color tests: cortex $\mathrm{K}+$ yellow, UV-; medulla $\mathrm{K}-$, $\mathrm{C}+$ slowly yellowish or $\mathrm{C}-, \mathrm{KC}+$ rose or reddish, $\mathrm{P}-, \mathrm{UV}-$.

TLC: atranorin, norlobaridone and loxodin.

Distribution: Argentina (Fleig 1997) and Brazil (Zahlbruckner 1930, Marcelli 2004). In Brazil it was recorded to MG (Hale \& Fletcher 1990, Fleig 1997), PR (Eliasaro 2001), RJ (Hale \& Fletcher 1990), RS (Spielmann 2006), SC and SP (Fleig 1997).

Specimens examined: BRAZIL. Rio Grande do SuL: Herveiras, 29²5'53.7'S, 52॰40'19.6”'W, 570 m alt., shaded place, 24-I-2004, A.A. Spielmann et al. 719 (SP); idem, on Eucalyptus trunk, open place, 24-I2004, A.A. Spielmann et al. 735 (SP), A.A. Spielmann et al. 940 (SP); Santa Cruz do Sul, margin from RST287, Km 102, 2941'03.3”'S, 52²5’33.6”W, 150 m alt., on Eucalyptus trunk, 28-VII-2003, A.A. Spielmann 390 (SP); Sinimbu, Cava Funda, 29²7’33.4”S, $52^{\circ} 31$ '05.1'W, $520 \mathrm{~m}$ alt., open place, 5-I-2004, A.A. Spielmann \& L.S. Canêz 968 (SP), A.A. Spielmann \& L.S. Canêz 971 (SP); idem, slightly shaded, 5-I-2004, A.A. Spielmann \& L.S. Canêz 1291 (SP).

Parmotrema homotomum is distinguished by the absence of vegetative propagules and the presence of norlobaridone (medulla $\mathrm{K}-, \mathrm{KC}+$ rose or reddish). The similar $P$. cetratum produces salazinic acid (medulla $\mathrm{K}+$ yellow $\rightarrow$ blood red) while in $P$. macrocarpum only caperatic acid is present (negative reactions).

Parmotrema simulans (Hale) Hale, Phytologia 28(4): 336. 1974 @ Parmelia simulans Hale, Phytologia 22(1): 32. 1971 E Rimelia simulans (Hale) Hale \& Fletcher, The Bryologist 93(1): 29. 1990. Type: BRAZIL. Minas Gerais: Sítio (nowadays Antônio Carlos), Vainio, Lichenes Braziliensis exsiccati $\mathrm{n}^{\circ} 918$ (lectotype TUR-V, selected by Hale 1971, isolectotype M), fide Fleig (1997) and Hale \& Fletcher (1990).

Figure 31
Thallus pale gray, lobate, membranaceous, loosely adnate, corticicolous, $15.5 \mathrm{~cm}$ broad. Lobes irregularly branched, contiguous to laterally overlapping, 2.5-10.0 mm wide, surface smooth, opaque to lustrous, sometimes pruinose, becoming reticulate cracked in the center, apical zone usually plane to slightly ascendant, rarely undulate, margin plane crenate to incise-crenate (sublacinulate); lateral marginal zone usually ascendant, undulate, margin usually lacinulate. Lacinules simple to irregularly branched, $0.5-3.0 \times 0.5-4.0 \mathrm{~mm}$, plane to slightly canaliculate, apex acute or truncate, evenly distributed; maculae distinct, reticular, laminal, forming cracks. Cilia black, simple to squarrose, $0.50-2.50 \times 0.02-0.05 \mathrm{~mm}$, few to abundant, evenly distributed, similar to the rhizines. Pustules and isidia absent. Soralia in the lacinules, capitate or extensive; soredia granular. Medulla white. Lower surface black, lustrous, smooth to rugose; marginal zone brown dark, lustrous, 1.5-2.5 mm wide, with rhizines, with attenuate limit, smooth. Rhizines black, simple, squarrose or irregularly branched, $0.50-2.50 \times 0.01-$ $0.05 \mathrm{~mm}$, abundant, evenly distributed. Apothecia absent [according to Fleig (1997), urceolate to patent, 5-10 $\mathrm{mm}$ in diameter, substipitate, base constrict, laminal, amphithecium sorediate, margin smooth, without cilia, disc perforate; ascospores 13.5-16.5 $\times$ 6.0-9.5 $\mu \mathrm{m}$, episporium 1.0-1.3 $\mu \mathrm{m}]$. Pycnidia laminal, rare, ostiole brown; conidia unknown.

Color tests: cortex $\mathrm{K}+$ yellow, $\mathrm{UV}-$; medulla $\mathrm{K}-, \mathrm{C}-$, $\mathrm{KC}-, \mathrm{P}-, \mathrm{UV}-$.

TLC: atranorin, caperatic acid.

Distribution: Africa (Hale 1971a, Krog \& Swinscow 1981), North America (Hale 1971a, Nash \& Elix 2002b, Esslinger 2008), Central America (Hale 1971a) and South America (Hale \& Fletcher 1990). In South America it is known to Brazil (Marcelli 2004) and Venezuela (Feuerer 2005). In Brazil it was recorded to MG (Hale 1971a, Hale \& Fletcher 1990, Ribeiro 1998), PR (Eliasaro 2001), RS (Spielmann 2006), SC (Fleig 1997) and SP (Ribeiro 1998).

Specimens examined: BRAZIL. Rio GRANDE do SUL: Herveiras, $29^{\circ} 25^{\prime} 53.7^{\prime}$ 'S , 52 40'19.6'W, $570 \mathrm{~m}$ alt., on Eucalyptus trunk, open place, 24-I-2004, A.A. Spielmann \& J. Putzke 1306 (SP).

Parmotrema simulans is recognizable by the formation of capitate to extensive soralia in the lacinules and the presence of caperatic acid (negative 
reactions). Parmotrema clavuliferum differs by the presence of salazinic acid (medulla $\mathrm{K}+$ yellow $\rightarrow$ blood red), and $P$. succinreticulatum, as the name says, succinprotocetraric and protocetraric acids are present (medulla $\mathrm{K}+$ weak yellow $\rightarrow$ orange, $\mathrm{KC}+$ weak yellow (Eliasaro \& Adler 1997).

\section{Literature cited}

Adler, M.T. 1989. Two new species in Parmeliaceae (Lichenized Ascomycotina) and new records for Argentina. Mycotaxon 35: 399-404.

Adler, M.T. 1992. Claves de los géneros y las especies de Parmeliaceae (Lichenes, Ascomycotina) de la provincia de Buenos Aires (Argentina). Boletín de la Sociedad Argentina de Botánica 28: 394-405.

Adler, M.T. \& Elix, J.A. 1987. Three new saxicolous species in Parmeliaceae (Lichenized Ascomycotina) from Argentina. Mycotaxon 30: 339-344.

Alava, R. 1998. Edvard August Vainio (1853-1929). In: M.P. Marcelli \& T. Ahti (eds.), Recollecting Edvard August Vainio. CETESB, São Paulo, pp. 1-14.

Aptroot, A. 1991. Lichens of Madagascar: New records and species of Parmeliaceae. Cryptogamie, Bryologie et Lichénologie 12: 149-154.

Awasthi, D.D. 1976. Lichen genus Parmelia in India I - Subgenera Parmelia and Amphigymnia. Biological Memoirs, Lichenology Series 1: 155-229.

Blanco, O., Crespo, A., Divakar, P.K., Elix, J.A. \& Lumbsch, H.T. 2005. Molecular phylogeny of parmotremoid lichens (Ascomycota, Parmeliaceae). Mycologia 97: 150-159.

Barros, L.M. de \& Xavier Filho, L. 1972. Catálogo dos liquens do Herbário do Departamento de Botânica da Universidade Federal de Pernambuco. In: D. AndradeLima (ed.), Anais da Sociedade Botânica do Brasil, XXIII Congresso Nacional de Botânica, Recife, pp. 45-55.

Brako, L., Dibben, M.J. \& Amaral, I. 1985. Preliminary notes on the macrolichens of Serra do Cachimbo, northcentral Brazil. Acta Amazonica, suplemento 15: $123-135$.

Brodo,I.M., Sharnoff, S.D. \& Sharnoff, S. 2001. Lichens of North America. Yale University Press, New Haven.

Bungartz,F. 2001. Analysis of lichen substances. Em http:// ces.asu.edu/ASULichens/plb400/ laboratory/chemistry/ tlc.html (access 10.2004).

Calvelo, S. \& Liberatore, S. 2002. Catálogo de los Líquenes de la Argentina. Kurtziana 29: 7-170.

Canêz,L.S.2005. A família Parmeliaceae na localidade de Fazenda da Estrela, município de Vacaria, Rio Grande do Sul, Brasil. Dissertação de mestrado, Instituto de Botânica, São Paulo.
Chen, J.B., Wang, S.L. \& Elix, J.A. 2003. Parmeliaceae (Ascomycota) lichens in China's Mainland. I. The genera Canomaculina, Parmelina, Parmelinella and Parmelinopsis. Mycotaxon 86: 19-29.

Culberson, W.L. 1973. The Parmelia perforata Group: Niche Characteristics of Chemical Races, Speciation by Parallel Evolution, and a New Taxonomy. The Bryologist 76: 20-29.

Culberson, W.L. 1991. A tribute to Mason Ellsworth Hale, Jr. The Bryologist 94: 90-93.

Dennis, R.W.G. 1965. Fungi Venezuelani: VII. Kew Bulletin 19: 231-273.

DePriest, P.T. \& Hale, B.W. 1998. New combinations in parmelioid genera (Ascomycotina: Parmeliaceae). Mycotaxon 67: 201-206.

Dey, J.P. 1974. Parmelia commensurata, a lichen new to North America. The Bryologist 77: 250-252.

Dodge, C.W. 1959. Some lichens of Tropical Africa. III. Parmeliaceae. Annals of the Missouri Botanical Garden 46: 39-193.

Eliasaro, S. 2001.Estudio taxonómico y florístico sobre las Parmeliaceae sensu stricto (Ascomycota Liquenizados) del Segundo Planalto del Estado de Paraná, Brasil. Buenos Aires. Tesis de Doctor, Universidad de Buenos Aires, Buenos Aires.

Eliasaro,S.\& Adler, M.T. 1997. Two new species and new reports in the Parmeliaceae sensu stricto (lichenized Ascomycotina) from Brazil. Mycotaxon 63: 49-55.

Eliasaro, S. \& Adler, M.T. 1998. Rimelia pontagrossensis, a new species in the Parmeliaceae sensu stricto (Lichenized Ascomycotina) from Brazil. Mycotaxon 66: 127-130.

Eliasaro, S. \& Adler, M.T. 2000. The species of Canomaculina, Myelochroa, Parmelinella, and Parmelinopsis (Parmeliaceae, lichenized Ascomycotina) from the "Segundo Planalto" in the state of Paraná, Brazil. Acta Botanica Brasilica 14: 141-149.

Eliasaro, S \& Donha, C. 2003. The genera Canomaculina and Parmotrema (Parmeliaceae, Lichenized Ascomycota) in Curitiba, Paraná State, Brazil. Revista Brasileira de Botânica 26: 239-247.

Elix, J.A. 1993. Progress in the generic delimitation of Parmelia sensu lato (Lichens, Ascomycotina: Parmeliaceae) and a synoptic key to the Parmeliaceae. The Bryologist 96: 359-383.

Elix,J.A. 1994. Parmeliaceae. Flora of Australia 55: 1-360.

Elix, J.A. 1997. The lichen genera Canomaculina and Rimeliella (Ascomycotina, Parmeliaceae). Mycotaxon 65: 475-479.

Elix,J.A. \& Hale, M.E. 1987. Canomaculina, Myelochroa, Parmelinella, Parmelinopsis and Parmotremopsis, five new genera in the Parmeliaceae (Lichenized Ascomycotina). Mycotaxon 29: 233-244. 
Elix, J.A. \& Schumm, F. 2001. A new species and new records in the lichen family Parmeliaceae (Ascomycotina) from the Philippines. Mycotaxon 79: 253-260.

Elix, J.A., Bawingan, P.A. \& Flores, Y.G. 2002. A new species and further new records in the lichen family Parmeliaceae (Ascomycotina) from the Philippines. Mycotaxon 81: 251-256.

Esslinger, T.L. 1972. A new Parmelia with diffractaic acid. The Bryologist 75: 79-81.

Esslinger, T.L. 2008. A cumulative checklist for the lichen-forming, lichenicolous and allied fungi of the continental United States and Canada. North Dakota State University: http://www.ndsu.nodak.edu/instruct/ esslinge/chcklst/chcklst7.htm (First Posted 1 December 1997, Most Recent Version (\#14) 8 October 2008) (access 12.2008).

Estrabou, C. \& Adler, M.T. 1998. Two new species of Parmotrema (Parmeliaceae sensu stricto, Lichenized Ascomycotina) from Argentina. Mycotaxon 66: 131136.

Feige, G.B. 1998. Etymologie der Wissenschaftlichen Gattungsnamen der Flechten. 1. Auflage. Published by the author, Essen.

Ferraro, L.I. \& Elix, J.A. 1993. Two new species of Parmeliaceae (Lichenized Ascomycota) from South America. Mycotaxon 49: 405-409.

Ferraro, L.I. \& Elix, J.A. 2000. A new species of Canomaculina (Lichenized Ascomycotina,Parmeliaceae) from Argentina. Mycotaxon 74: 391-394.

Feuerer, T. (ed.) 2005. Checklists of lichens and lichenicolous fungi. Version 1 January 2005. http:// www.checklists.de (access 02.2005).

Feuerer, T., Ahti, T. \& Vitikainen, O. 1998. Lichenological investigations in Bolivia. In: M.P. Marcelli \& M.R.D. Seaward (eds.). Lichenology in Latin America: history, current knowledge and applications. CETESB, São Paulo, pp 71-86.

Fleig, M. 1997. Os gêneros Parmotrema, Rimelia e Rimeliella (Lichenes - Ascomycotina, Parmeliaceae) no Rio Grande do Sul, Brasil. Tese de doutorado, Universidade de São Paulo, São Paulo.

Fleig, M. 1999. New species in the lichen genus Parmotrema (Parmeliaceae, Ascomycotina) from southern Brazil. Mycotaxon 71: 199-206.

Fleig, M. \& Riquelme, I. 1991. Liquens de Piraputanga, Mata Grosso do Sul, Brasil. Acta Botanica Brasilica 5: 3-12.

Galloway, D.J. 1985. Flora of New Zealand, Lichens. Government Printer, Wellington.

Greuter, W., Mcneill, J., Barrie, F.R., Burdet, H.M., Demoulin, V., Filgueiras, T.S., Nicolson, D.H., Silva, P.C., Skog, J.E., Trehane, P., Turland, N.J. \& Hawksworth, D.L. (eds.) 2003. Código Internacional de Nomenclatura Botânica (Código de Saint Louis). Adotado pelo XVI Congresso Internacional de Botânica, Saint Louis, Missouri, julho-agosto de 1999. Tradução de Bicudo, C.E.M. \& Prado, J. Instituto de Botânica, International Association for Plant Taxonomy, Sociedade Botânica de São Paulo, São Paulo.

Hale, B.W. \& DePriest, P.T. 1999. Mason E. Hale's list of epithets in the parmelioid genera. The Bryologist 102: 462-544.

Hale, M.E. 1959. New or interesting species of Parmelia in North America. The Bryologist 62: 16-24.

Hale, M.E. 1960. A revision of the South American species of Parmelia determined by Lynge. Contributions from the United States National Herbarium 36: 1-41.

Hale, M.E. 1965. A monograph of Parmelia subgenus Amphigymnia. Contributions from the United States National Herbarium 36: 193-358.

Hale, M.E. 1971a. Five new Parmeliae from Tropical America. Phytologia 22: 30-35.

Hale, M.E. 1971b. Morden-Smithisonian expedition to Dominica: The lichens (Parmeliaceae). Smithsonian Contributions to Botany 4: 1-25.

Hale, M.E. 1974a. New combinations in the lichen genus Parmotrema Massalongo. Phytologia 28: 334-339.

Hale, M.E. 1974b. Bulbothrix, Parmelina, Relicina, and Xanthoparmelia, four new genera in the Parmeliaceae (Lichenes). Phytologia 28: 479-490.

Hale, M.E. 1974c. Notes on species of Parmotrema (Lichenes: Parmeliaceae) containing yellow pigments. Mycotaxon 1: 105-116.

Hale, M.E. 1974d. New combinations in the lichen genus Pseudoparmelia Lynge. Phytologia 29 (3): 188-191.

Hale, M.E. 1976. A monograph of the lichen genus Parmelina Hale (Parmeliaceae). Smithsonian Contributions to Botany 33: 1-60.

Hale, M.E. 1977. New species in the lichen genus Parmotrema Mass. Mycotaxon 5: 432-448.

Hale, M.E. 1979. How to know the Lichens. The PicturedKey Nature Series. Wm. C. Brown, Dubuque.

Hale, M.E. 1984. An historical review of the genus concept in Lichenology. Nova Hedwigia Beiheft 79: 11-23.

Hale, M.E. 1986. New species in the lichen family Parmeliaceae (Ascomycotina). Mycotaxon 25: 85-93.

Hale, M.E. 1990. New species of Parmotrema (Ascomycotina: Parmeliaceae) from Tropical America . Bibliotheca Lichenologica 38: 109-119.

Hale, M.E. \& Ahti, T. 1986. An earlier name for Parmotrema perlatum "(Huds.) Choisy" (Ascomycotina: Parmeliaceae). Taxon 35: 133-134.

Hale, M.E. \& Cole, M. 1988. Lichens of California. California Natural History Guides $n^{\circ} 54$. University of California Press, Berkeley.

Hale, M.E. \& Fletcher, A. 1990. Rimelia Hale \& Fletcher, a new lichen genus (Ascomycotina: Parmeliaceae). The Bryologist 93: 23-29. 
Hawksworth, D.L. 2004. Rediscovery of the original material of Osbeck's Lichen chinensis and the reinstatement of the name Parmotrema perlatum (Parmeliaceae). Herzogia 17: 37-44.

Hawksworth, D.L., Blanco, O., Divakar, P.K., Ahti, T. \& Crespo, A. 2008. A first checklist of parmelioid and similar lichens in Europe and some adjacent territories, adopting revised generic circumscriptions and with indications of species distributions. The Lichenologist 40: $1-21$.

Huneck, S. \& Yoshimura, I. 1996. Identification of lichen substances. Springer, Berlin.

Jackson, D.W. \& Hopkins, A.W. 1980. New Additions to the Lichen Flora of Texas and the United States. The Bryologist 83: 532-533.

Jungbluth, P. 2006. A família Parmeliaceae (fungos liquenizados) em fragmentos de cerrados do estado de São Paulo. Dissertação de mestrado, Instituto de Botânica, São Paulo.

Kantvilas, G., Elix, J.A. \& Jarman, S.J. 2002. Tasmanian Lichens: identification, distribution and conservation status. Flora of Australia Supplementary Series 15: 1-274.

Krog, H. 1974. Parmelia ultralucens, a new lichen species in subgenus Amphigymnia. The Bryologist 77: 253-256.

Krog, H. 1991. Lichenological observations in low montane rainforest of eastern Tanzania. In: Tropical lichens: Their systematics, conservation, and ecology D.J. Galloway (ed.). Systematics Association Special Volume 43. Clarendon Press, Oxford, pp. 85-94.

Krog, H. \& Swinscow, T.D.V. 1981. Parmelia subgenus Amphigymnia in East Africa. Bulletin of the British Museum (Natural History) Botany series 9: 143-231.

Krog, H. \& Swinscow, T.D.V. 1983. A new species and new combinations in Parmotrema (Parmeliaceae). Lichenologist 15: 127-130.

Kurokawa, S. 1974. Four new species of Parmelia from Brazil. Bulletin of the National Science Museum Tokyo 17: 297-300.

Kurokawa,S. 1985. Parmelia diffractaica (Parmeliaceae, Lichenes) new to Brazil. Journal of Japanese Botany 60: 47-48.

Kurokawa, S. 1987. New or noteworthy species of Parmelia, subgenus Amphigymnia (Lichenes) producing alectoronic and $\alpha$-collatolic acids. Bulletin of the National Science Museum Tokyo, series B. 13: 11-15.

Kurokawa,S. 1991a. Rimeliella, a new lichen genus related to Rimelia of the Parmeliaceae. Annals of the Tsukuba Botanical Garden 10: 1-14.

Kurokawa, S. 1991b. Japanese Species and Genera of the Parmeliaceae. Journal of Japanese Botany 66: 152-159.

Kurokawa, S. 1993. Nepalese genera and species of Parmeliaceae with notes on three additional and one rare species. Annals of the Tsukuba Botanical Garden 12: $75-81$.
Kurokawa, S. 2001. Taxonomic notes on Parmelia reparata (Parmeliaceae, Lichenes) and the related species. Bulletin of the National Science Museum Tokyo, Series B27: 1-10.

Kurokawa, S. \& Lai, M.J. 2001. Parmelioid lichen genera and species in Taiwan. Mycotaxon 77: 225-284.

Kurokawa, S. \& Moon, K.H. 1998. Three new species and a new combination in Parmotrema (Parmeliaceae). Bulletin of the Botanic Gardens of Toyama 3: 17-23.

Lamb, I.M. 1963. Index nominum lichenum. Inter annos 1932 et 1960 divulgatorum. Ronald Press, New York.

Louwhoff, S.H.J.J. \& Elix, J.A. 1998. The lichen family Parmeliaceae (Ascomycotina) on Lord Howe Island, Australia. Mycotaxon 68: 429-463.

Louwhoff, S.H.J.J. \& Elix, J.A. 1999. Parmotrema and allied genera in Papua New Guinea. Bibliotheca Lichenologica 73: 1-152.

Louwhoff, S.H.J.J. \& Elix, J.A. 2000. The lichens of Rarotonga, Cook Islands, South Pacific Ocean II: Parmeliaceae. The Lichenologist 32: 49-55.

Louwhoff, S.H.J.J. \& Elix, J.A. 2002. The Parmeliaceae (lichenized Ascomycota) of New Caledonia. The Lichenologist 34: 373-394.

Lynge, B. 1914. Die Flechten der ersten Regnellschen Expedition. Die Gattungen Pseudoparmelia gen. nov. und Parmelia Ach. Arkiv för botanik 13: 1-172.

Lynge, B. 1925. On some South American lichens of the Genera Parmelia, Candelaria, Theloschistes and Pyxine. Nyt Magazin for Naturvidenskaberne 62: 83-97.

Maas-Geesteranus, R.A. 1947. Revision of the lichens of the Netherlands I. Parmeliaceae. Blumea 6: 1-199.

Malcolm, W.N. \& Galloway, D.J. 1997. New Zealand Lichens. Checklist, Key, and Glossary. Museum of New Zealand Te Papa Tongarewa, Wellington.

Marcelli, M.P. 1991. Aspects of the foliose lichen flora of the southern-central coast of São Paulo State, Brazil. In: D.J. Galloway (ed.). Tropical lichens: Their systematics, conservation, and ecology. Systematics Association Special Volume 43. Clarendon Press, Oxford, pp. 151-170.

Marcelli, M.P. 1992. Ecologia Liquênica nos Manguezais do Sul-Sudeste Brasileiro. Bibliotheca Lichenologica 47: 1-288.

Marcelli, M.P. 1998. History and current knowledge of Brazilian Lichenology. In: Marcelli, M.P. \& Seaward, M.R.D. (Eds). Lichenology in Latin America: history, current knowledge and applications. CETESB, São Paulo, pp. 25-45.

Marcelli, M.P. 2004. Checklist of lichens and lichenicolous fungi of Brazil. Version 1: June 2004. http://www. biologie.uni-hamburg.de/checklists/brazil_l.htm (access 12.2004).

Marcelli, M.P.\& Canêz,L.S. 2008. Novelties on Southern Brazilian Parmeliaceae. Mycotaxon 105: 225-234.

Marcelli, M.P. \& Ribeiro, C.H. 2002. Twenty-one new species of Parmeliaceae (lichenized fungi) from 
southeastern Brazil. Mitteilungen aus dem Institut für Allgemeine Botanik Hamburg 30-32: 125-155.

Massalongo, A. 1860. Esame comparativo di alcuni generi di licheni. Atti dell'Istituto Veneto di scienze, lettere ed arti 5: 247-267, 313-337.

Mata García, L.B. 1994. Rimelia bonplandii, a new lichen species (Ascomycotina: Parmeliaceae). The Bryologist 97: 432-433.

McNeill, J., Barrie, F.R., Burdet, H.M., Demoulin, V., Hawksworth, D.L., Marhold, K., Nicolson, D.H., Prado, J., Silva, P.C., Skog, J.E., Wiersema, J.H. \& Turland, N.J. (eds.) 2007. International Code of Botanical Nomenclature (Vienna Code) adopted by the Seventeenth International Botanical Congress Vienna, Austria, July 2005. Regnum Vegetabile 146. Gantner, Ruggell.

Moon, K.H., Kurokawa, S. \& Kashiwadani, H. 2001. The genus Rimelia (Lichens) from Hawaiian Island. The Journal of Japanese Botany 76: 321-328.

Nagaoka, L.Y. \& Marcelli, M.P. 1989. Liquens da área de reserva do Parque Estadual das Fontes do Ipiranga. Acta Botanica Brasilica (suplemento) 3: 95-98.

Nash III, T.H. \& Elix, J.A. 2002a. Parmotrema. In: T.H. Nash III, B.D. Ryan, C. Gries \& F. Bungartz (eds.). Lichen Flora of the greater Sonoran Desert Region. v. 1. Lichens Unlimited, Arizona State University, Tempe.

Nash III, T.H. \& Elix, J.A. 2002b. Rimelia. In: T.H. Nash III, B.D. Ryan, C. Gries \& F. Bungartz (eds.). Lichen Flora of the greater Sonoran Desert Region. v. 1. Lichens Unlimited, Arizona State University, Tempe.

Nylander, W. 1872. Observata lichenologica in Pyrenaeis orientalibus. II. La Preste-Costabonne. Flora 55: 545554.

Orange,A.,James,P.W.\& White,F.J.2001.Microchemical methods for the identification of lichens. British Lichen Society, London.

Osorio, H.S. 1970a. Lichens from Cantera, south Paraguay. Comunicaciones Botánicas del Museo de Historia Natural de Montevideo 4(50): 1-3.

Osorio, H.S. 1970b. Contribution to the lichen flora of Uruguay IV. Some lichens from northern Uruguay. Nova Hedwigia 19: 339-344.

Osorio, H.S. 1970c. Contribution to the lichen flora of Uruguay. V. Lichens from "Paso Yacare", Salto County. Comunicaciones Botánicas del Museo de Historia Natural de Montevideo 4(52): 1-2.

Osorio, H.S. 1970d. Contribution to the lichen flora of Argentina IV. New or additional records. The Bryologist 73: 392-394.

Osorio, H.S. 1972. Contribution to the lichen flora of Uruguay. VII.A preliminary catalogue. Comunicaciones Botánicas del Museo de Historia Natural de Montevideo 4: 1-46.
Osorio, H.S. 1976. Contribution to the lichen flora of Argentina VIII. Lichens from Punta Lara, Buenos Aires Province. The Bryologist 79: 358-360.

Osorio, H.S. 1977a. Contribution to the lichen flora of Brazil II. Lichens from Guarapuava, Paraná State. Dusenia 10: 101-102.

Osorio, H.S. 1977b. Contribution to the lichen flora of Brazil III. Lichens from Western Paraná. Acta Biológica Paranaense 6: 3-7.

Osorio, H.S. 1980. Contribution to the lichen flora of Uruguay XV. Additional records to the Rio Uruguay lichen flora. Phytologia 46: 137-142.

Osorio, H.S. 1989. Contribution to the lichen flora of Brazil. XXIII. Lichens from São Paulo city. Mycotaxon 36: 161-162.

Osorio, H.S. 1992a. Contribución a la flora liquénica del Uruguay. XXV. Líquenes publicados entre 1972 a 1991. Anales del Museo Nacional de Historia Natural de Montevideo, 2nd Series 8: 43-70.

Osorio, H.S. 1992b. Contribution to the lichen flora of Brazil. XXIX. Lichens from Ponta Porá, Mato Grosso do Sul. Comunicaciones Botánicas del Museo de Historia Natural de Montevideo 5: 1-6.

Osorio, H.S. 1995. Contribution to the Lichen Flora of Uruguay. XXVIII. Lichens from Southern Rocha. Comunicaciones Botánicas del Museo de Historia Natural de Montevideo 5: 1-12.

Osorio, H.S. 1997. Contribution to the Lichen Flora of Brazil. XXXIV. Lichens from Laguna, Santa Catarina State. Comunicaciones Botánicas del Museo de Historia Natural de Montevideo 6: 1-4.

Osorio, H.S. 2003. Contribution to the lichen flora of Uruguay. XXXVIII. Some collections from Eastern Uruguay. Comunicaciones Botánicas del Museo de Historia Natural de Montevideo 6: 1-11.

Østhagen, H. \& Krog,H. 1976. Contribution to the Lichen Flora of the Canary Islands. Norwegian Journal of Botany 23: 221-242.

Pereira, W.R. \& Marcelli, M.P. 1989. Liquens da Reserva Biológica do Alto da Serra de Paranapiacaba. Acta Botanica Brasilica 3: 89-94.

Purvis, O.W., Coppins, B.J., Hawksworth, D.L., James, P.W. \& Moore, D.M. (eds.) 1992. The lichen flora of Great Britain and Ireland. Natural History Museum, London.

Ribeiro, C.H. 1998. A família Parmeliaceae (Ascomycota liquenizados) em regiões montanhosas dos estados de Minas Gerais, Rio de Janeiro e São Paulo. Dissertação de mestrado, Universidade de São Paulo, São Paulo.

Sérusiaux, E. 1984. Contribution to the study of lichens from Kivu (Zaire), Rwanda and Burundi. VIII. New and Interesting species of parmeliaceous lichens. The Bryologist 87: 1-11. 
Sipman, H.J.M. 2005. Mason Hale's key to Parmotrema, revised edition: key to wide-lobed parmelioid species occurring in Tropical America (genera Canomaculina, Parmotrema, Rimelia, Rimeliella). Last update 28 October 2005. http://www.bgbm.org/sipman/keys/ Neoparmo.htm (access 10.2008).

Spielmann, A.A. 2005. A família Parmeliaceae (fungos liquenizados) nos barrancos e peraus da encosta da Serra Geral, Vale do Rio Pardo, Rio Grande do Sul, Brasil. Dissertação de mestrado, Instituto de Botânica, São Paulo.

Spielmann, A.A. 2006. Checklist of lichens and lichenicolous fungi of Rio Grande do Sul (Brazil). Caderno de Pesquisa Série Biologia 18: 7-125.

Spielmann, A.A. \& Marcelli, M.P. 2008. Parmeliaceae (Ascomycota liquenizados) nos barrancos e peraus da encosta da Serra Geral, Vale do Rio Pardo, Rio Grande do Sul, Brasil. I. Introdução e chave para os gêneros. Iheringia, série Botânica 63: 159-169.

Swinscow, T.D.V.\& Krog, H. 1988. Macrolichens of East Africa. British Museum of Natural History, London.

Tavares, C.N. 1945. Contribuição para o estudo das Parmeliáceas Portuguesas. Portugaliae Acta Biologica, série B, 1: 1-210.

Vainio, E.A. 1890. Étude sur la classification naturelle et la morphologie des Lichens du Brésil. Pars prima. Acta Societatis pro Fauna et Flora Fennica 7: 1-247.

Vainio, E.A. 1909. Lichenes. In: J. Schmidt, Flora of Koh Chang. Contributions to the knowledge of the vegetation of the Gulf of Siam. Part. IX. Botanisk Tidsskrift 29: 104-152.

Vareschi, V.1962. Resultados liquenológicos de excursiones efectuadas en Venezuela. II. Acta Biologica Venezuelica 3: 201-232.

Vareschi, V.1973. Resultados liquenológicos de excursiones efectuadas en Venezuela. $N^{\circ} 3$. Catálogo de los Líquenes de Venezuela. Acta Botanica Venezuelica 8: 177-245.

Winnem, B. 1975. Parmelia subgenus Amphigymnia in Ethiopia. Norwegian Journal of Botany 22: 139-166.

Zahlbruckner, A. 1909. Lichenes. In: V. Schiffner (ed.). Ergebnisse der botanischen Expedition der Kaiserlichen Akademie der Wissenschaften nach Südbrasilien 1901. Band II:Tallophyta und Bryophyta. Denskschriften der Mathematsch-Naturwissenschaftlichen Klasse der Kaiserlichen Academie der Wissenschaften 83: 87-211.

Zahlbruckner, A. 1926a. Lichenes, Spezieller Teil. In: A. Engler \& K. Prantl (eds.). Die natürlichen Pflanzenfamilien, 2nd ed. v. 8. Wilhelm Engelmann, Leipzig, pp. 67-270.

Zahlbruckner, A. 1926b. Afrikanische Flechten (Lichenes). Botanische Jahrbücher für Systematik, Pflanzengeschichte und Pflanzengeographie 60: 468552.

Zahlbruckner, A. 1930. Catalogus lichenum universalis. v. 6. Gebrüder Borntraeger, Leipzig.

Zahlbruckner, A. 1932. Catalogus lichenum universalis. v. 8. Gebrüder Borntraeger, Leipzig. 

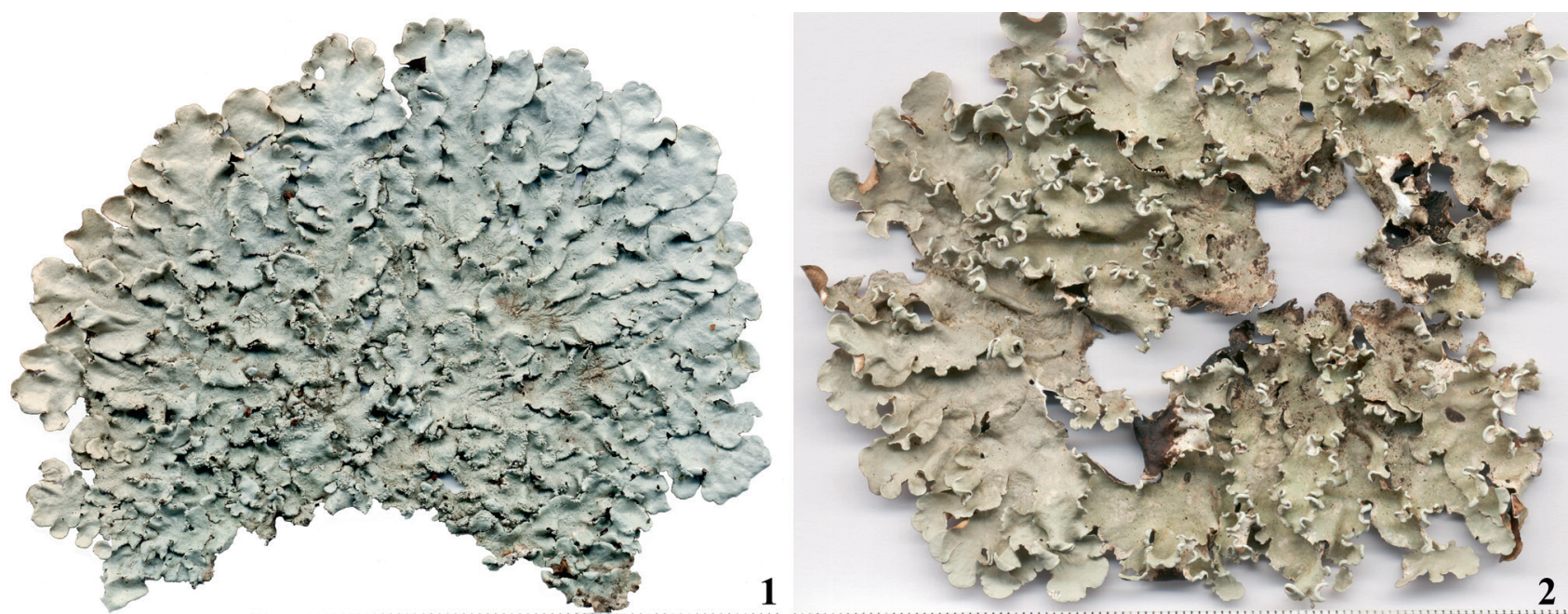

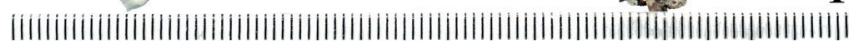
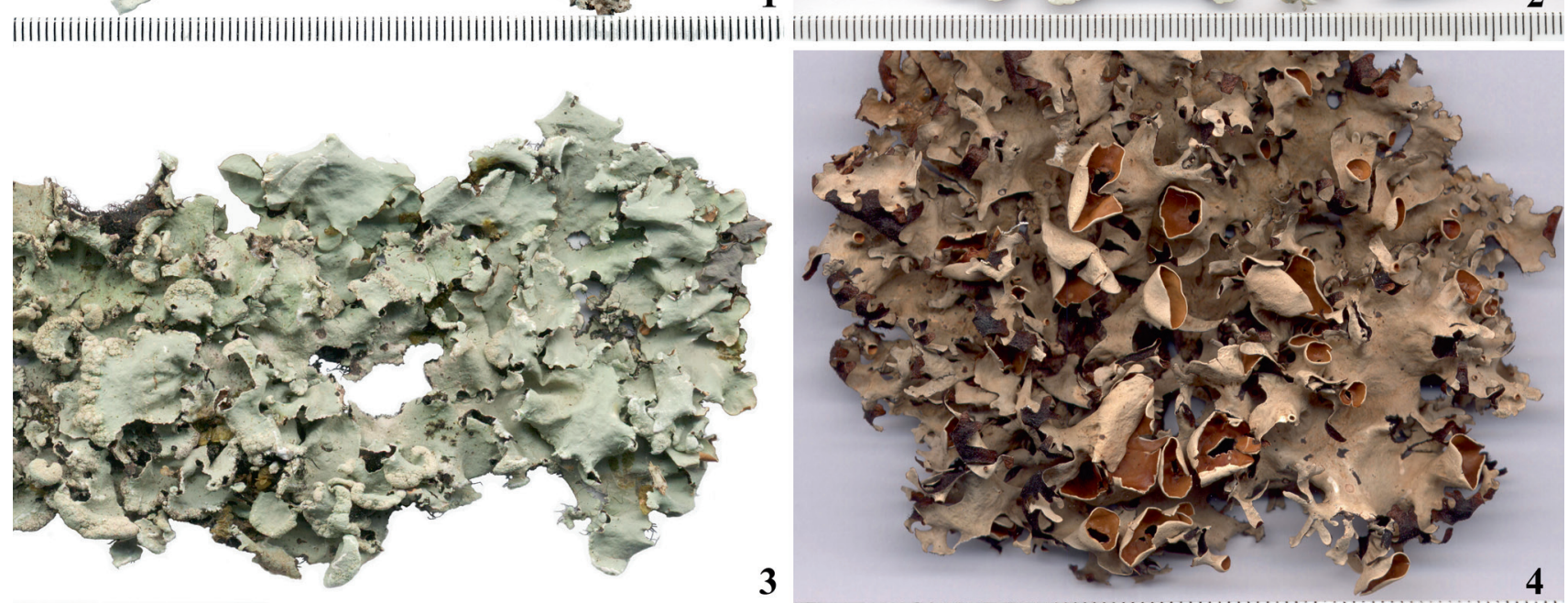

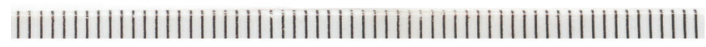
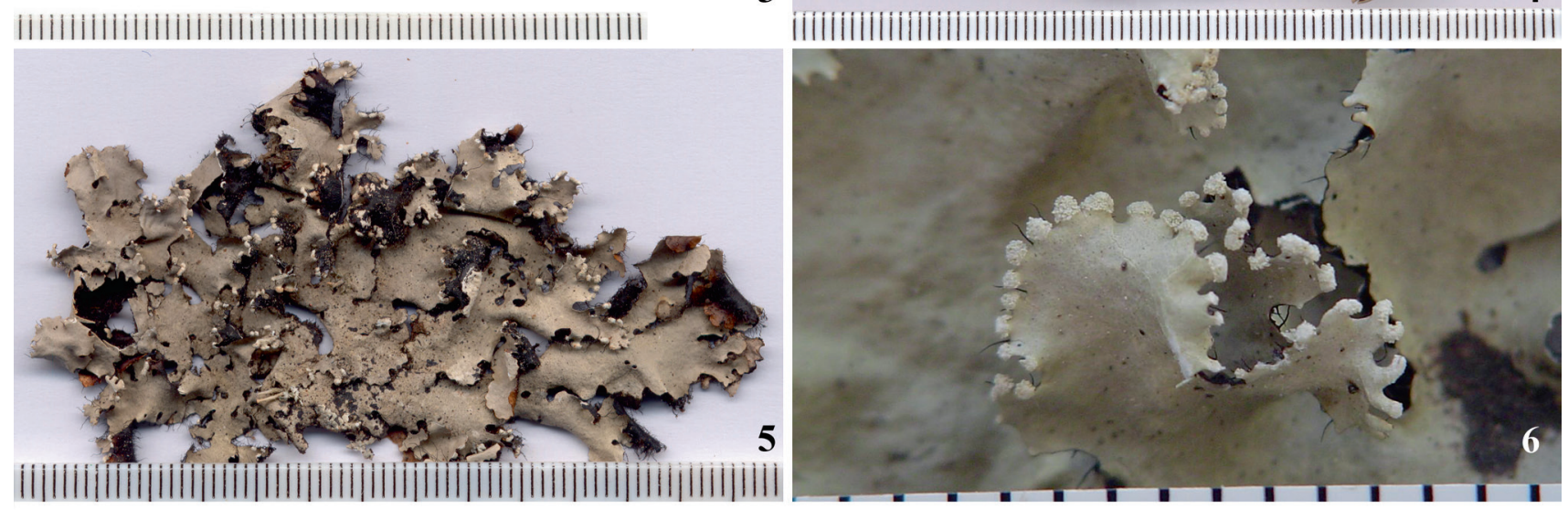

Figures 1-6. Species of Parmotrema from Serra Geral. 1. Parmotrema alidactylatum (Spielmann \& Canêz 1205). 2. Parmotrema austrosinense (Spielmann \& Canêz. 1088). 3. Parmotrema bangii (Spielmann \& Canêz 700). 4. Parmotrema cetratum (Spielmann \& Canêz 752). 5. Parmotrema clavuliferum (Spielmann \& Canêz, 1347). 6. Parmotrema clavuliferum, soralia in the lacinules (Spielmann \& Canêz 1359). Scales in millimeters. 

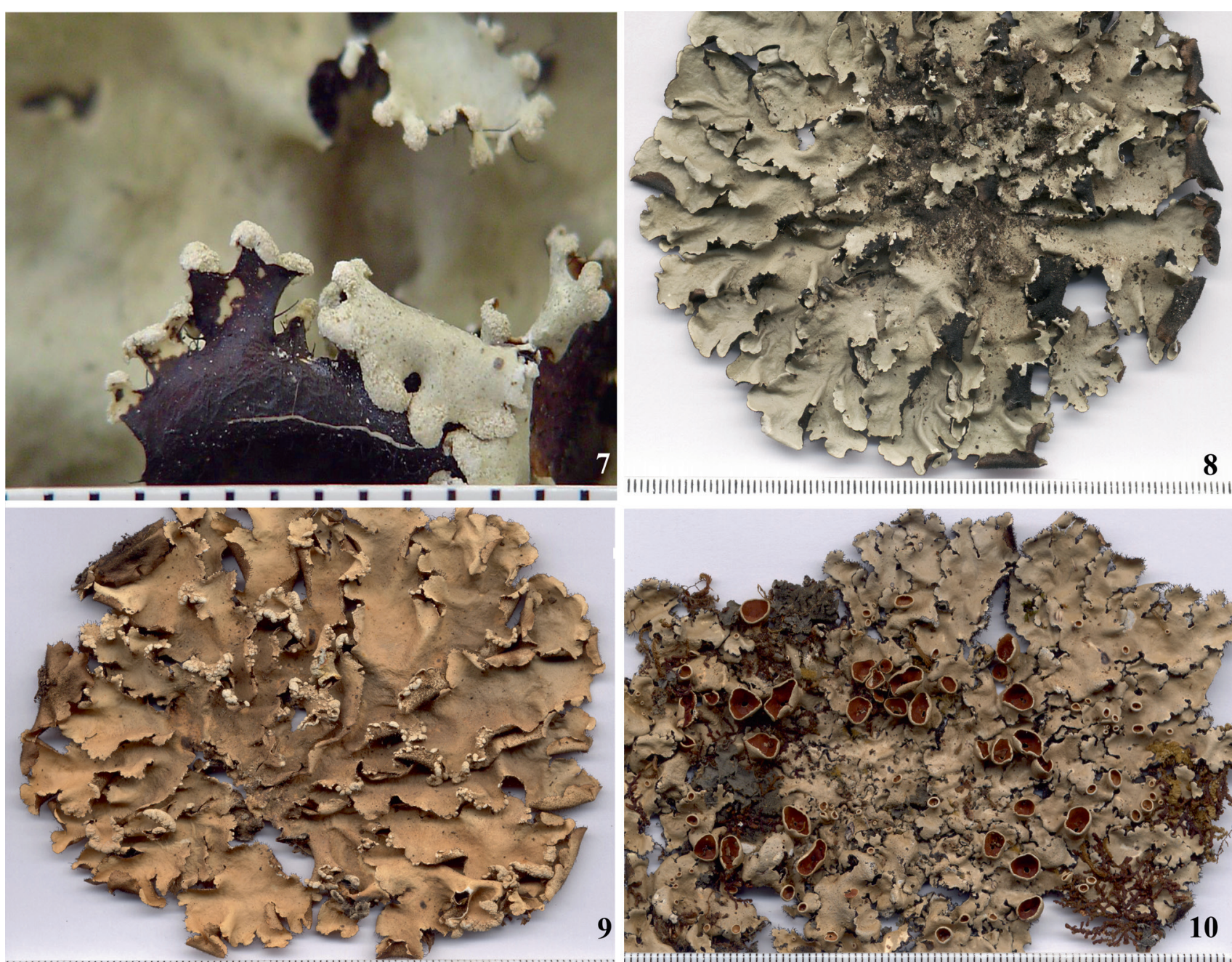

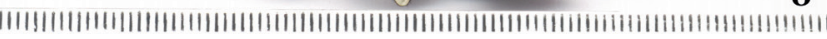
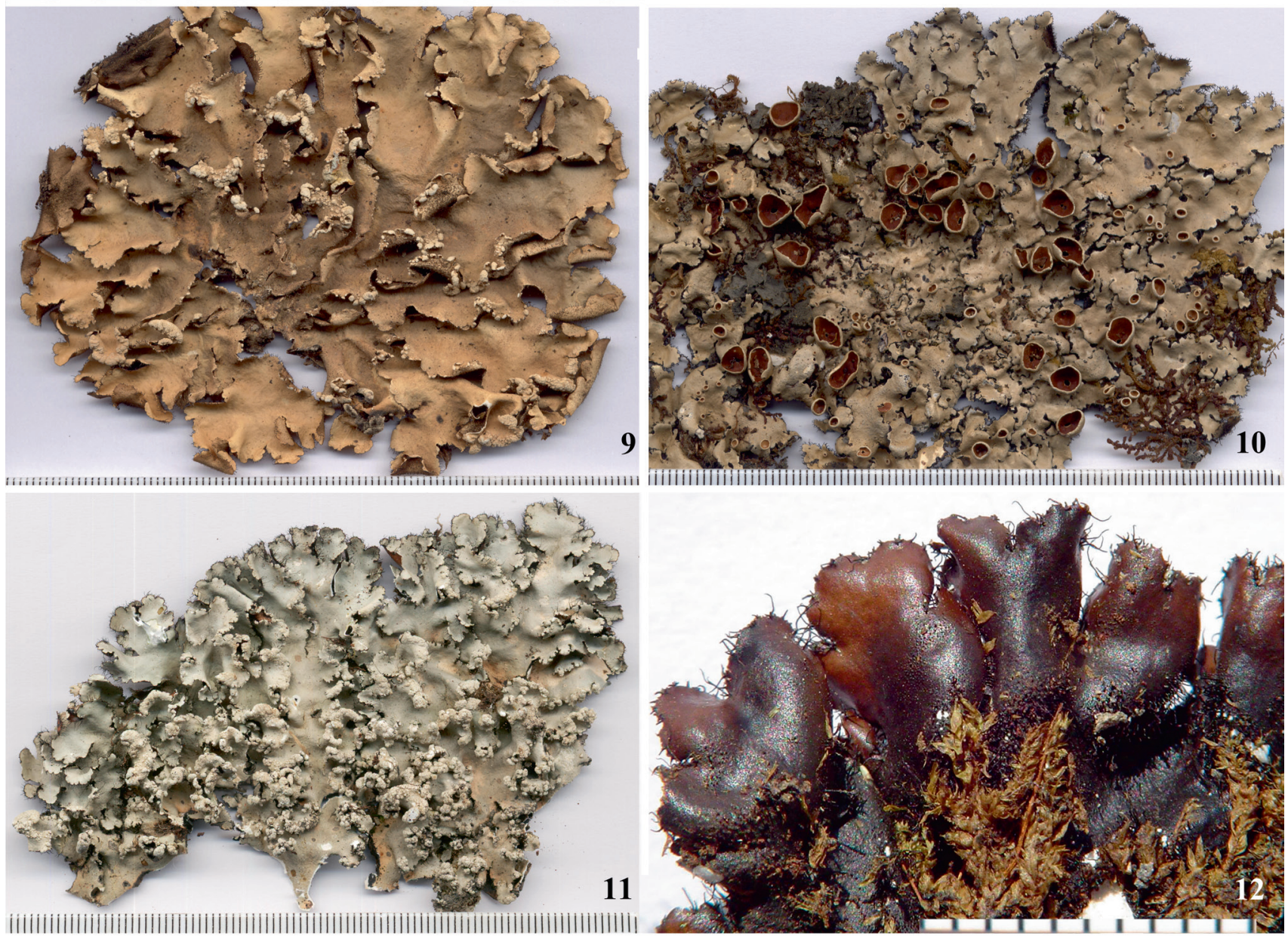

Figures 7-12. Species of Parmotrema from Serra Geral. 7. Parmotrema clavuliferum, lacinules undersurface (Spielmann \& Canêz 722). 8. Parmotrema commensuratum (Spielmann 30). 9. Parmotrema conferendum (Spielmann 24). 10. Parmotrema consors (Spielmann \& Canêz 690). 11. Parmotrema diffractaicum (Spielmann et al. 1163). 12. Parmotrema diffractaicum, underside marginal zone (Spielmann et al. 1163). Scales in millimeters. 

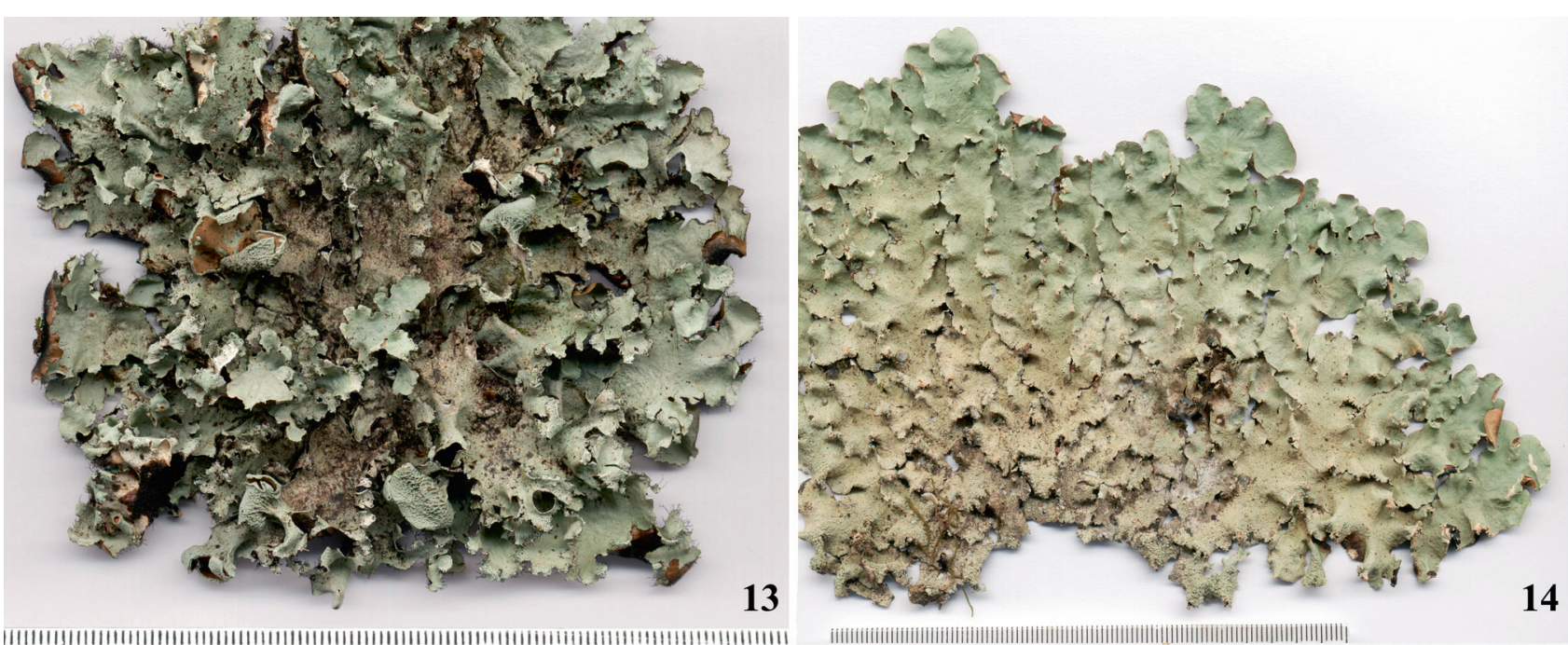

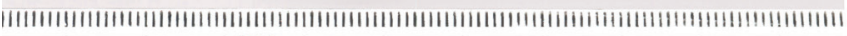
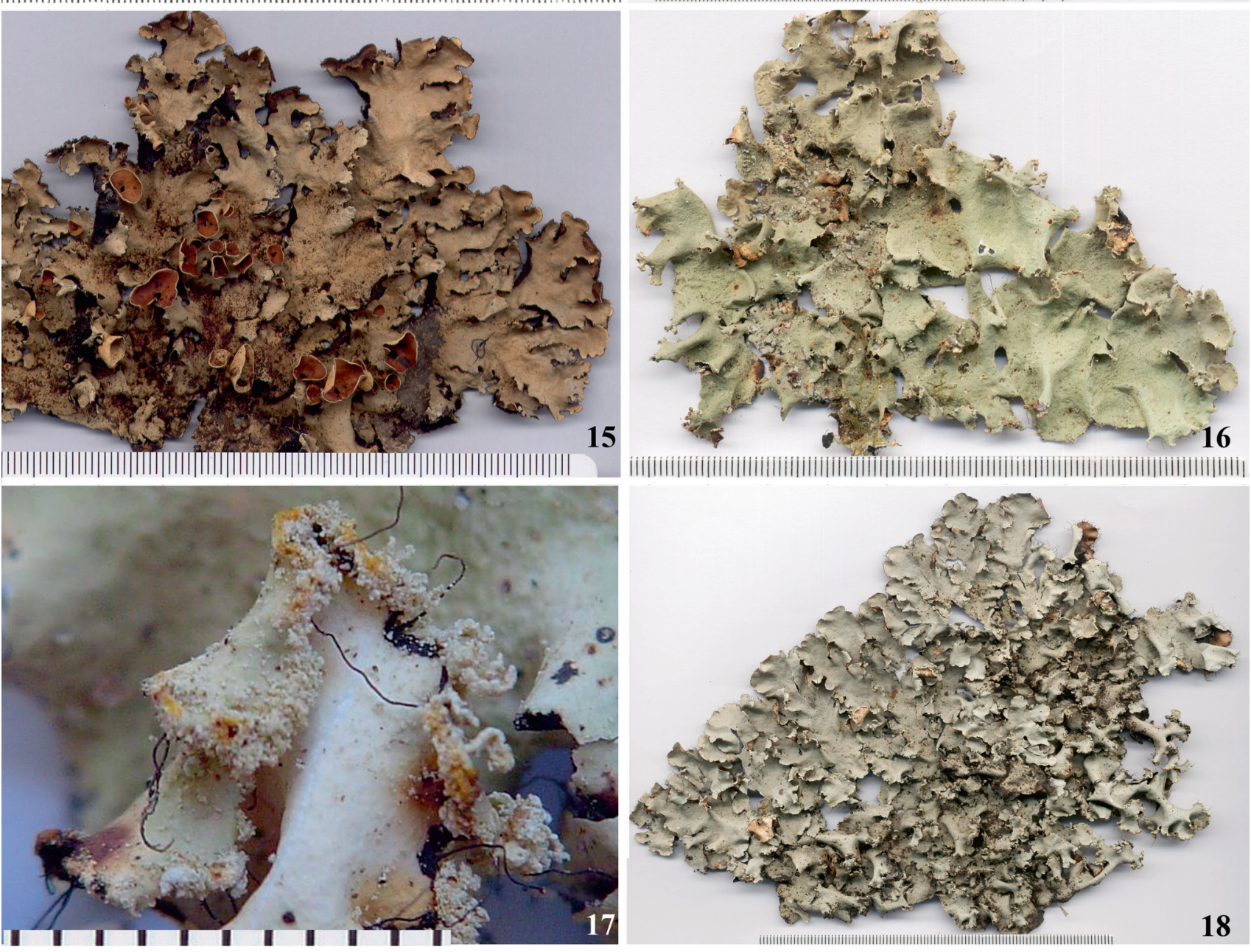

Figures 13-18. Species of Parmotrema from Serra Geral. 13. Parmotrema eciliatum (Spielmann 410). 14. Parmotrema flavomedullosum (Spielmann \& Sulzbacher 743). 15. Parmotrema homotomum (Spielmann \& Canêz 971). 16. Parmotrema hypomiltoides (Spielmann \& Sulzbacher 1262). 17. Parmotrema hypomiltoides, soredia (Spielmann \& Sulzbacher 1262). 18. Parmotrema indicum (Spielmann \& Canêz 931). Scales in millimeters. 

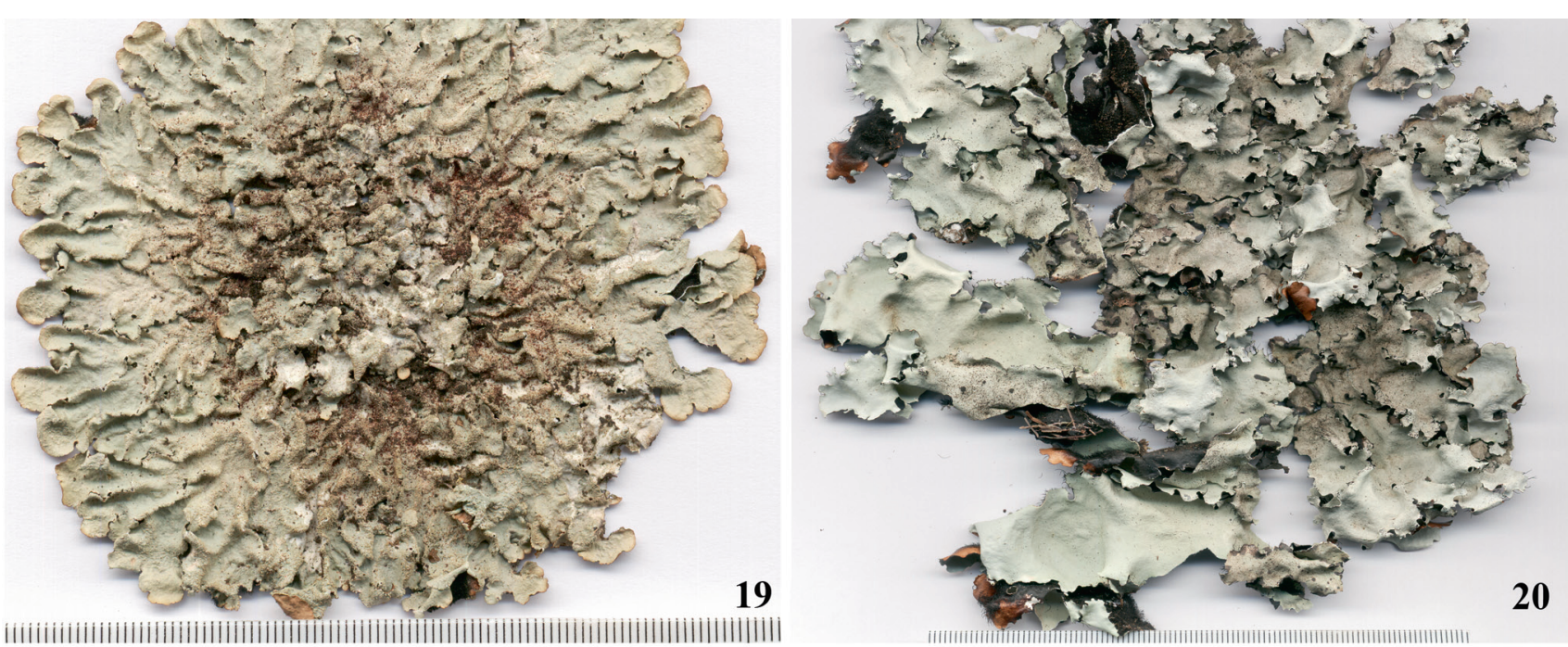

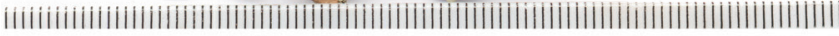
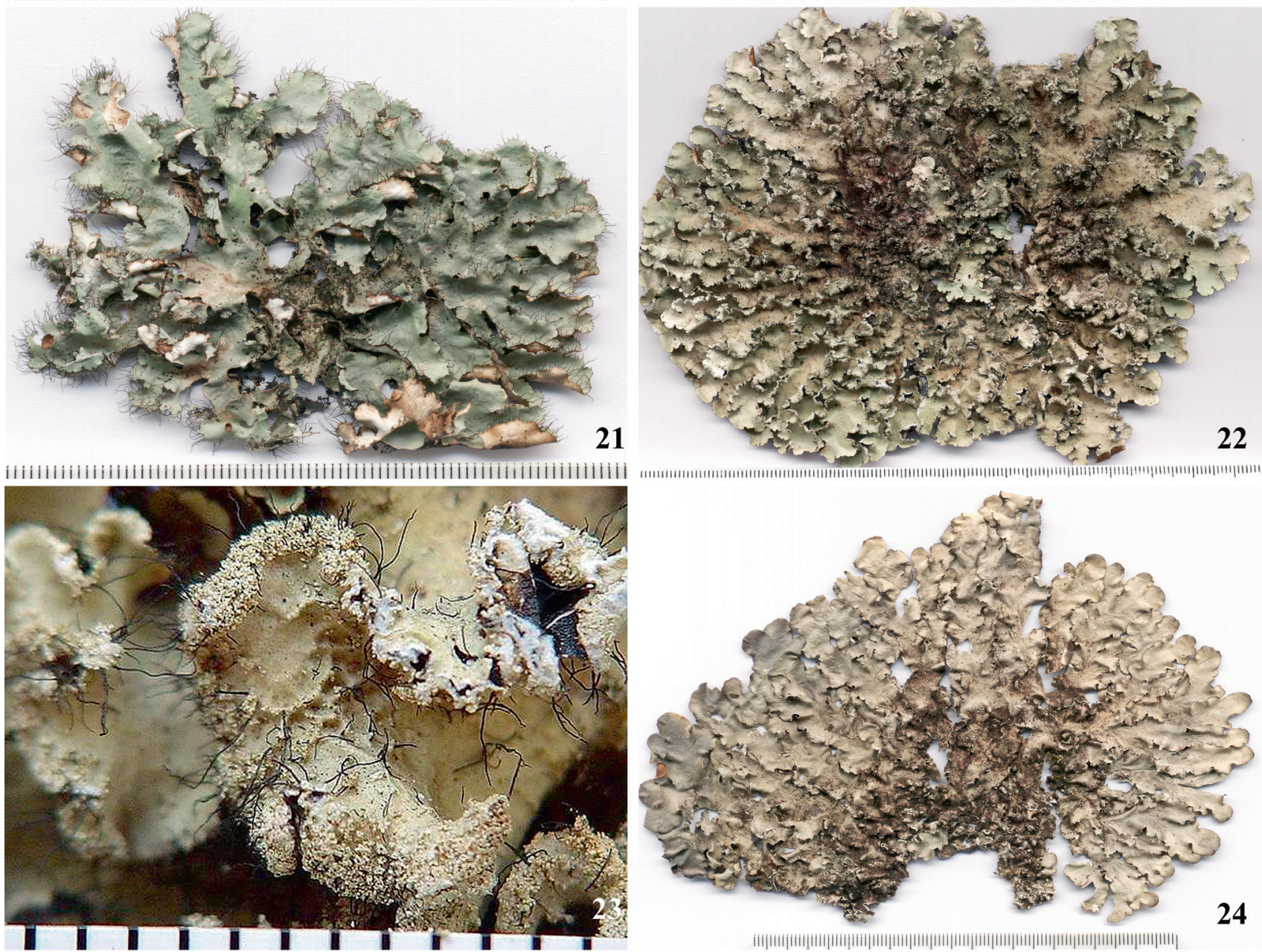

Figures 19-24. Species of Parmotrema from Serra Geral. 19. Parmotrema internexum (Spielmann \& Canêz, 1167). 20. Parmotrema mantiqueirense (Spielmann et al.938). 21. Parmotrema melanothrix (Spielmann \& Canêz 1033). 22. Parmotrema mellissii (Spielmann 111). 23. Parmotrema mellissii, isidiate wrinkles and soredia (Spielmann 111). 24. Parmotrema mordenii (Spielmann 110). Scales in millimeters. 

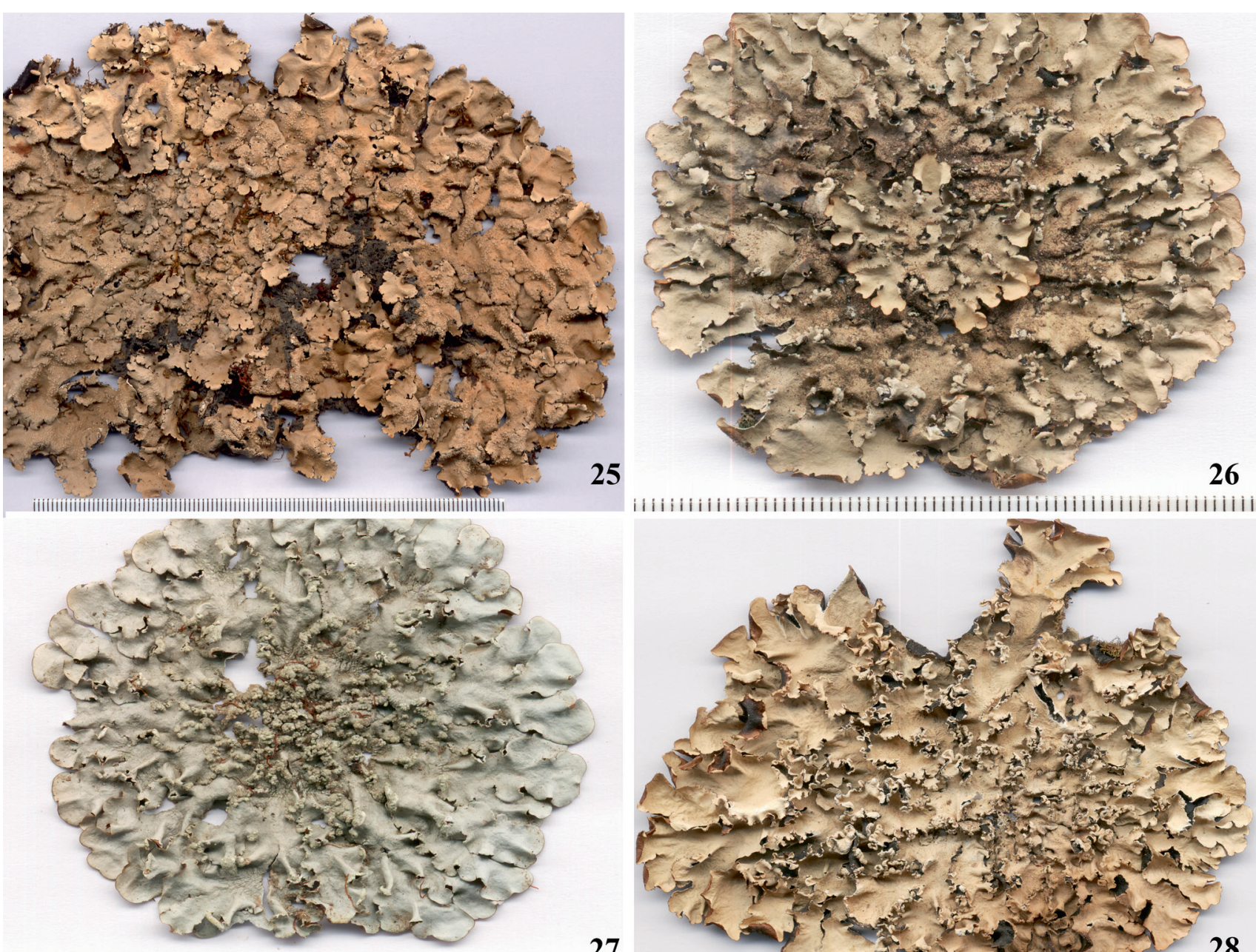

27
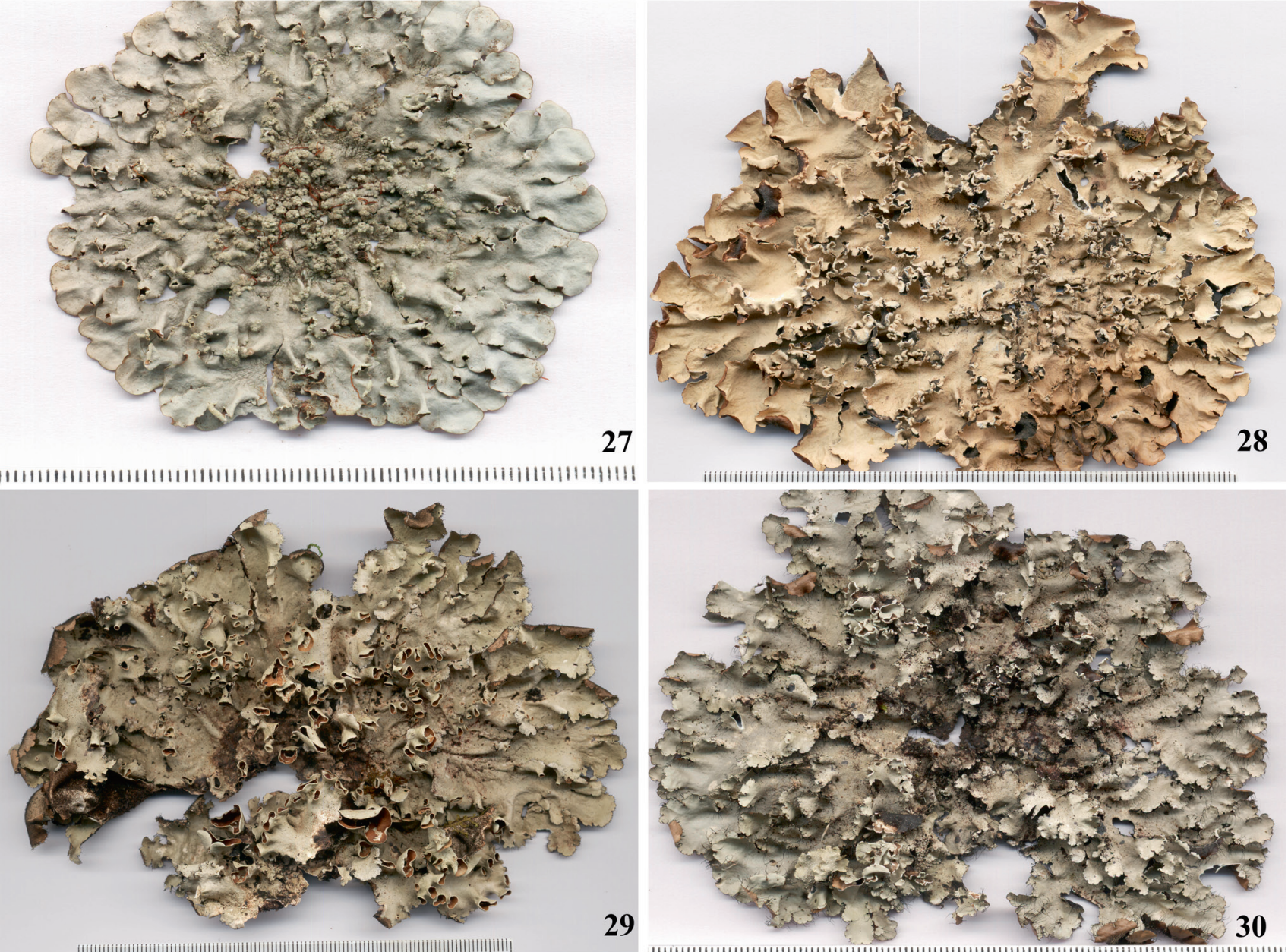

Figures 25-30. Species of Parmotrema from Serra Geral. 25. Parmotrema muelleri (Spielmann 685). 26. Parmotrema perlatum (Spielmann 65). 27. Parmotrema praesorediosum (Spielmann 399). 28. Parmotrema rampoddense (Spielmann 17). 29. Parmotrema recipiendum (Spielmann 352). 30. Parmotrema sancti-angeli (Spielmann 332). Scales in millimeters. 

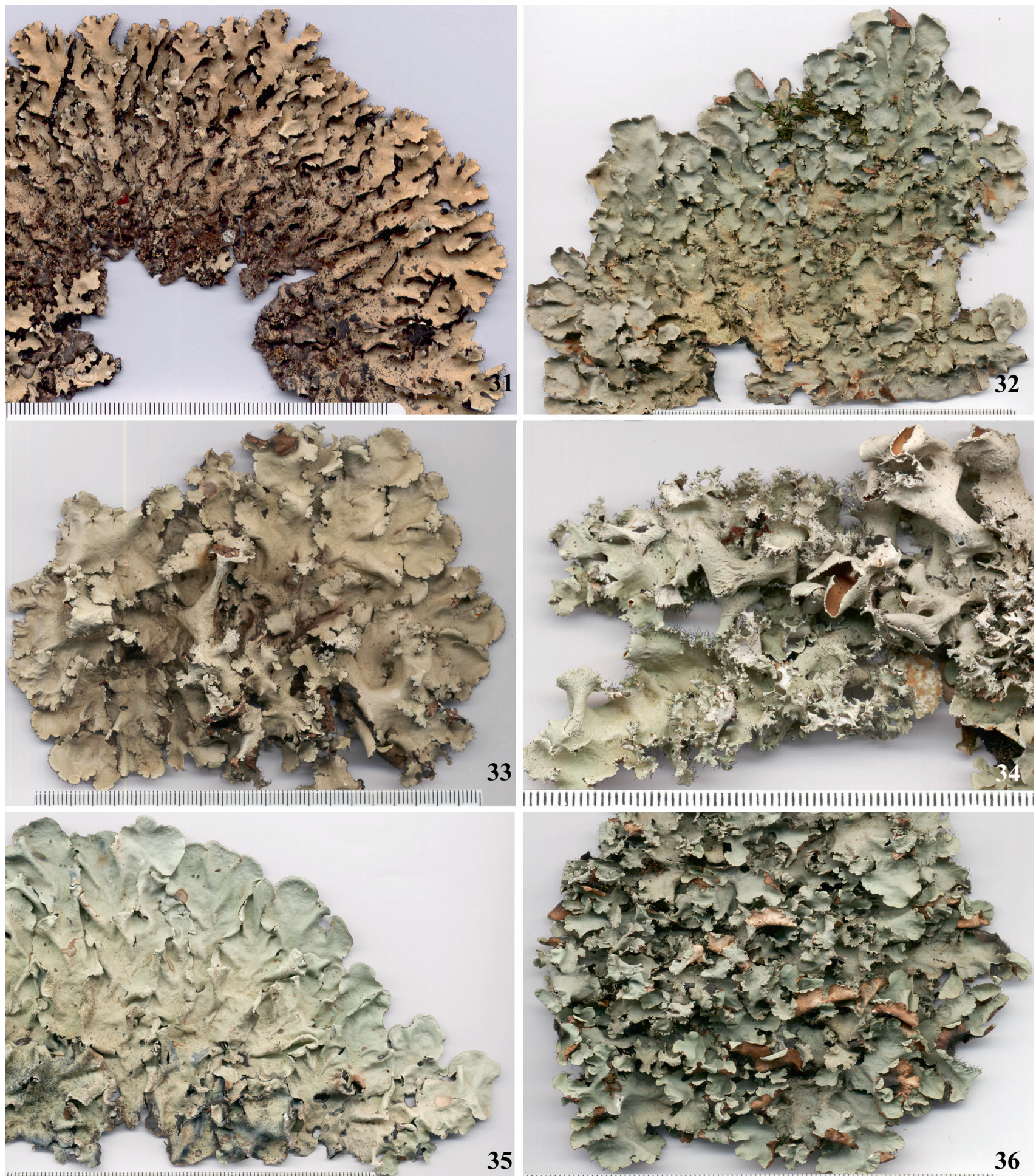

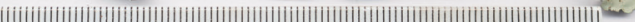

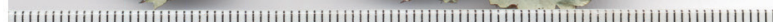

Figures 31-36. Species of Parmotrema from Serra Geral. 31. Parmotrema simulans (Spielmann \& Putzke 1306). 32. Parmotrema spinibarbe (Spielmann \& Canêz 1161). 33. Parmotrema subcaperatum (Spielmann \& Canêz 976). 34. Parmotrema subrugatum (Spielmann 360$) .35$. Parmotrema tinctorum (Spielmann et al.932). 36. Parmotrema wainioi (Spielmann \& Putzke 728). Scales in millimeters. 

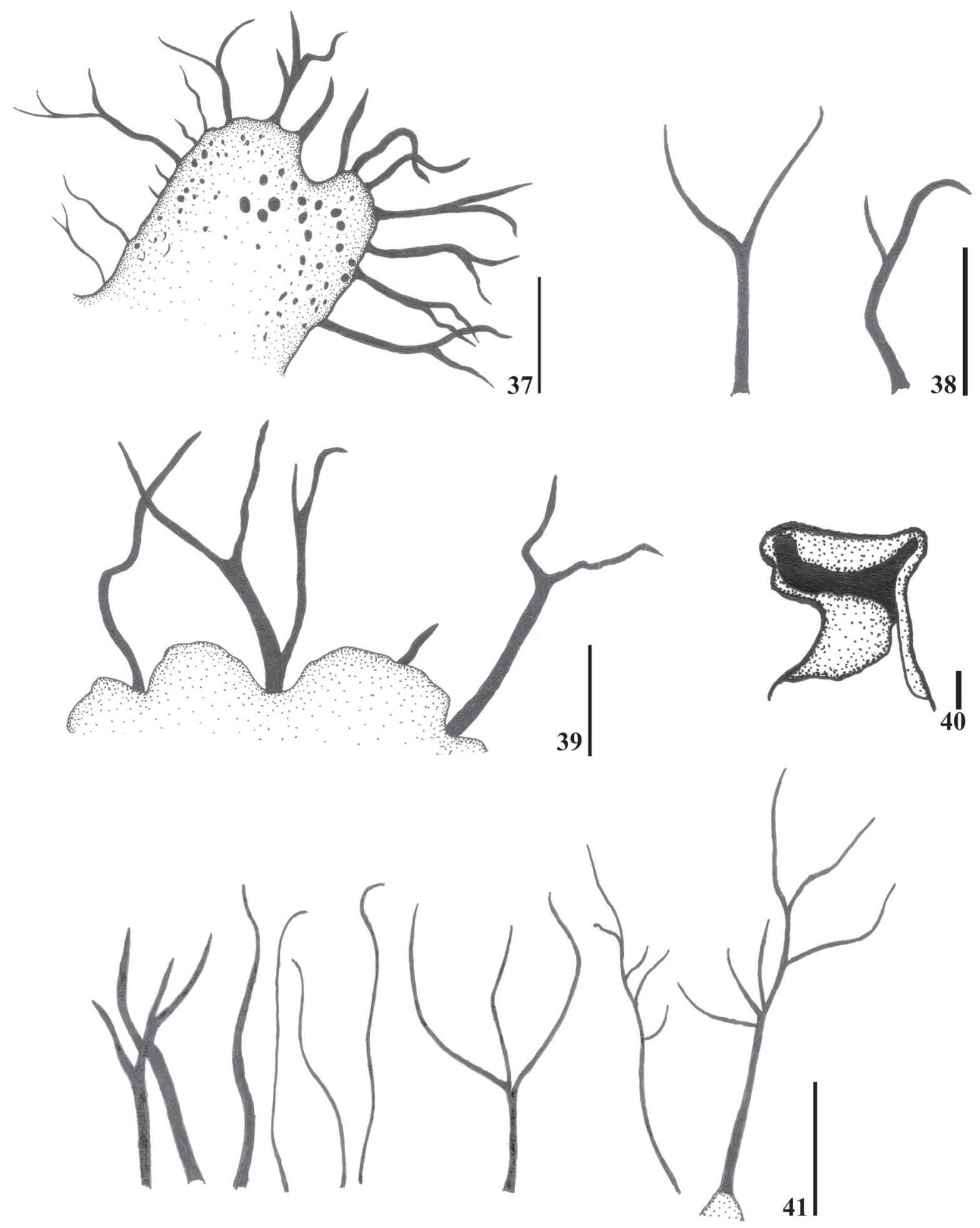

Figures 37-41. Species of Parmotrema from Serra Geral. 37. Parmotrema eciliatum, lobe with cilia (Spielmann 419). 38. Parmotrema wainioi, cilia (Spielmann \& Putzke 728). 39. Parmotrema indicum, cilia (Spielmann \& Canêz. 931). 40. Parmotrema flavomedullosum, "T" like lobe (Spielmann \& Sulzbacher 1037). 41. Parmotrema mellissii, cilia (Spielmann 111). Bar = $1 \mathrm{~mm}$. 